\title{
REAÇÃO DE ACESSOS DE Capsicum spp. A Colletotrichum sp., AGENTE CAUSAL DA ANTRACNOSE DAS SOLANÁCEAS
}

\author{
Mônica Juliani Zavaglia Pereira
}

\author{
Dissertação apresentada à Escola Superior de \\ Agricultura "Luiz de Queiroz", Universidade de São \\ Paulo, para obtenção do título de Mestre em \\ Agronomia, Área de Concentração: Fitopatologia.
}

P I R A C I C A B A

Estado de São Paulo - Brasil

Janeiro - 2005 
REAÇÃO DE ACESSOS DE Capsicum spp. A Colletotrichum sp., AGENTE CAUSAL DA ANTRACNOSE DAS SOLANÁCEAS

\author{
Mônica Juliani Zavaglia Pereira \\ Engenheiro Agrônomo
}

Orientador: Prof. Dr. NELSON SIDNEI MASSOLA JÚNIOR

\begin{abstract}
Dissertação apresentada à Escola Superior de Agricultura "Luiz de Queiroz", Universidade de São Paulo, para obtenção do título de Mestre em Agronomia, Área de Concentração: Fitopatologia.
\end{abstract}

P I R A C I C A B A

Estado de São Paulo - Brasil

Janeiro - 2005 
Dados I nt ernacionai s de Cat al ogação na Publi cação ( CI P) DI VI SÃO DE BI BLI OTECA E DOCUMENTAÇÃO - ESALQI USP

Pereira, Mônica Juliani Zavaglia

Reação de acessos de Capsicum spp. a Colletotrichum sp., agente causal da

antracnose das solanáceas / Mônica Juliani Zavaglia Pereira. - - Piracicaba, 2005. $74 \mathrm{p}$

Dissertação (Mestrado) - - Escola Superior de Agricultura Luiz de Queiroz, 2005. Bibliografia.

1. Antracnose 2. Cruzamento vegetal 3. Fungo fitopatogênico 4. Genótipo 5. Linhagem vegetal 6 . Pimenta 7. Pimentão 8. Resistência genética vetegal 9. Solanaceae I. Título

CDD 635.643 
'Nós preferimos acreditar, persistir e trabalhar muito.

Não é fácil, mas sempre possível.

Mais que isso, é gratificante vencer desafios, encontrar saídas quando as portas estão fechadas, cumprir metas e tornar o sonho realidade. Aprendemos, estamos crescendo e nos orgulhamos disso. Sempre com humildade e nunca com arrogância. Sucesso à todos.” 


\section{AGRADECIMENTOS}

À Deus, por estar presente em todos os momentos da vida;

Ao meu pai Hélio Vianei da Luz Pereira, à minha mãe Evanildes Terezinha Zavaglia Pereira e à minha irmã Núbia Micheli Zavaglia Pereira, que sempre me deram o apoio, o conforto e o estímulo necessários para a conclusão de todos os meus projetos e pelo amor incondicional;

Aos Profs. Dr. Nelson Sidnei Massola Jr e Dr. Cyro Paulino da Costa pela oportunidade de orientação e conhecimentos compartilhados;

Aos meus amigos Eng. Agr. M.Sc. César Antônio Michel e Profs. M.Sc. Nelson Neto e M.Sc. José Luiz Tragnago, pelo apoio e confiança e por sempre terem me incentivado a continuar estudando;

Ao Angelo Sussel, pelo carinho, apoio e paciência em todos os momentos;

Ao doutorando Fernando Sala e ao funcionário de campo Rogério, pela ajuda no desenvolvimento do trabalho;

Ao pesquisador Dr. Gilmar P. Henz, da Embrapa Hortaliças, pelas dicas de análise estatística dos dados;

Ao CNPq pela concessão de bolsa de estudos durante um ano. 


\section{SUMÁRIO}

Página

LISTA DE FIGURAS ........................................................................... vii

LISTA DE TABELAS …......................................................................... viii

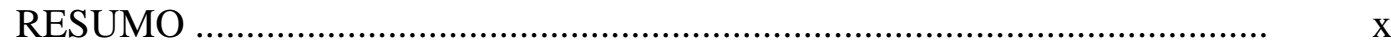

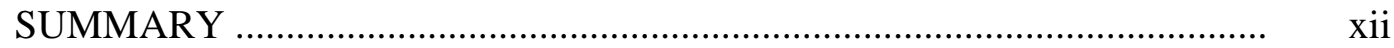

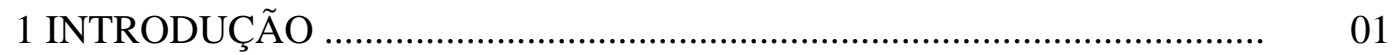

2 REVISÃO DE LITERATURA _.................................................................. 03

2.1 Espécies do gênero Capsicum ..................................................................... 03

2.2 Produção e comercialização ......................................................................... 04

2.3 Ocorrência de Colletotrichum sp. em Capsicum spp. .................................. 04

2.4 Análise da resistência .............................................................................. 07

3 MATERIAL E MÉTODOS .......................................................................... 14

3.1 Local .............................................................................................. 14

3.2 Coleção de acessos do Banco de Germoplasma de Capsicum spp. da ESALQ/USP .............................................................................. 14

3.3 Preparação do inóculo .......................................................................... 15

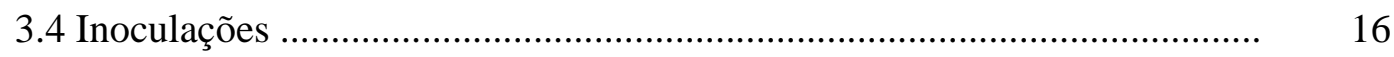

3.4.1 Plântulas ........................................................................................... 16

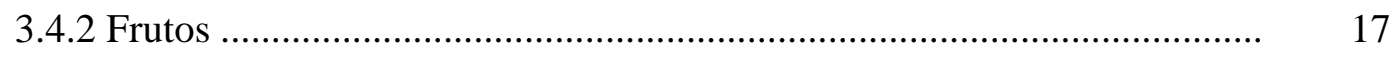

3.5 Critérios de avaliações das reações do hospedeiro à antracnose ................ 18

3.6 Delineamento experimental e análise estatística dos resultados .................. 19

4 RESULTADOS E DISCUSSÃO ............................................................... 20

4.1 Reação de acessos de Capsicum spp. à antracnose, em plântulas .............. 20 
4.2 Reação de acessos de Capsicum spp. à antracnose, em frutos 23

4.3 Análise de correlação 32

4.4 Classificação de reação de resistência - Teste de Cluster ... 34

5 CONCLUSÕES 37

REFERÊNCIAS BIBLIOGRÁFICAS 38

APÊNDICES 


\section{LISTA DE FIGURAS}

Página

1 Reação de acessos resistente versus suscetível de $C$. chinense à antracnose. Em (A) a testemunha resistente PBC 932 e em (B) a testemunha suscetível n ${ }^{\circ} 45$ - 152225, aos 19 dias após a inoculação

2 Percentagem de acessos agrupados nas diferentes classes de velocidade de crescimento de lesões (cm/dia)

3 Percentagem de acessos em relação ao período latente 


\section{LISTA DE TABELAS}

Página

1 Germoplasma de Capsicum spp., acessos, local de origem, cor do fruto quando verde e quando maduro, formato do fruto e espécie de Capsicum, caracterizado quanto à reação à antracnose em plântulas e em frutos

2 Reação de acessos de $C$. annuum, $C$. baccatum e $C$. chinense quanto a ocorrência de antracnose em plântulas, de acordo com a severidade de doença, baseada em uma escala de notas, e incidência, aos 3, 10 e 19 dias após a inoculação (DAI), no primeiro e segundo experimentos de inoculação

3 Avaliação em plântulas de acordo com a severidade de doença e incidência, aos 3, 10 e 19 dias após a inoculação, das progênies oriundas de retrocruzamentos entre (C. annuum x $C$. chinense) $\times$. annuum, geração F4RC1 e [(C. annuum x $C$. chinense $) \times C$. annuum $] \times$. annuum, geração F3RC2

4 Reação de acessos de Capsicum annuum, C. baccatum, C. chinense e C. frutescens quanto à ocorrência de antracnose em frutos, de acordo com 0 diâmetro de lesões e incidência aos 3, 7 e 11 dias após a inoculação (DAI), velocidade de crescimento de lesão, período latente e classificação dos genótipos, pelo Teste Cluster para agrupamento em classes de resistência, nos dois experimentos de inoculação

5 Análise de correlação entre o primeiro e o segundo experimento de inoculação em frutos, para as variáveis diâmetro de lesões aos 11 DAI e velocidade de crescimento de lesões 
6 Reação de progênies de Capsicum oriundos de retrocuzamentos entre as espécies (C. annuum x C. chinense) x C. annuum, numerados de 1 a 19 , representando a geração F3RC1 e entre as espécies [( $C$. annuum x $C$. chinense) $\mathrm{x}$ C. annuum] $\mathrm{x}$ C. annuum, numerados de 20 a 40, representando a geração F2RC2. Avaliação com base no diâmetro de lesão e incidência aos 3, 7 e 11 dias após a inoculação, velocidade de crescimento de lesão e período latente

7 Análise de correlação entre o diâmetro de lesões aos 3, 7 e 11 dias após a inoculação e velocidade de crescimento de lesões nos frutos e a severidade nas plântulas aos 3, 10 e 19 DAI e teste F. Genótipos de Capsicum annuum

8 Análise de correlação entre o diâmetro de lesões aos 3, 7 e 11 dias após a inoculação e velocidade de crescimento de lesões nos frutos e a severidade nas plântulas aos 3, 10 e 19 DAI e teste F. Genótipos de Capsicum baccatum

9 Análise de correlação entre o diâmetro de lesões aos 3, 7 e 11 dias após a inoculação e velocidade de crescimento de lesões nos frutos e a severidade nas plântulas aos 3, 10 e 19 DAI e teste F. Genótipos de Capsicum chinense

10 Comparação entre diâmetro de lesões nos frutos aos 11 dias após a emergência e a severidade nas plântulas aos 19 dias após a emergência, para alguns acessos de $C$. annuum 


\title{
REAÇÃO DE ACESSOS DE Capsicum spp. A Colletotrichum sp., AGENTE CAUSAL DA ANTRACNOSE DAS SOLANÁCEAS
}

\author{
Autor: MÔNICA JULIANI ZAVAGLIA PEREIRA \\ Orientador: Prof. Dr. NELSON SIDNEI MASSOLA JUNIOR
}

\section{RESUMO}

A importância do cultivo de espécies do gênero Capsicum vem crescendo nos últimos anos no Brasil, e consequentemente, a ocorrência de doenças torna-se um problema relevante. A antracnose é a mais comum e destrutiva doença de Capsicum no Brasil e em vários países, podendo ocasionar perdas de até 100\%. Seu controle usando resistência genética seria altamente desejável. O objetivo deste trabalho foi (i) caracterizar a reação à antracnose de 90 acessos de Capsicum annuum, 30 de $C$. baccatum, 16 de $C$. chinense e um de $C$. frutescens; (ii) estabelecer a correlação da reação à antracnose entre plântulas e frutos de Capsicum e; (iii) avaliar a reação à antracnose das progênies F3RC1 (C.annuum x C. chinense - resistente) x C. annuum e F2RC2 [(C. annuum x C. chinense) x C. annuum] x C. annuum. Para as inoculações, foram utilizados quatro isolados do fungo Colletotrichum sp. provenientes de pimentão e um isolado de pimenta, obtidos de folhas e frutos doentes. As suspensões de inóculo foram preparadas na concentração de $1 \times 10^{6}$ conídios/ml, separadamente para cada isolado. Após ajustada a concentração das suspensões, estas foram misturadas, a fim de reduzir efeitos de possível variabilidade patogênica dos isolados. O delineamento utilizado foi inteiramente casualizado com 20 repetições para plântulas e 15 repetições para frutos verdes destacados. Os ensaios foram conduzidos duas vezes. Nas inoculações 
das plântulas, foi adicionado 5\% de caldo de cana à suspensão, como fonte exógena de energia ao patógeno. A inoculação nas plântulas foi realizada no estádio de primeira folha verdadeira completamente expandida, pela aspersão da suspensão de esporos até o ponto de escorrimento. As plântulas foram mantidas em câmara úmida por 24 horas antes e 72 horas após a inoculação. O ensaio foi instalado em sala climatizada com temperatura de $26+/-2^{\circ} \mathrm{C}$ e fotoperíodo de 12 horas. Foi avaliada a severidade de doença, usando uma escala de notas e também a incidência da doença, com base na percentagem de plântulas doentes. A inoculação nos frutos foi realizada pela deposição de uma gota de $20 \mu \mathrm{l}$ da suspensão de esporos na parte mediana dos frutos. Posteriormente, com o auxílio de uma agulha entomológica, foi realizado um ferimento abaixo da gota. Os frutos inoculados foram mantidos em câmara úmida durante o período de avaliação. As avaliações foram realizadas pela mensuração do diâmetro médio das lesões, período latente, velocidade de crescimento da lesão e incidência. Baseando-se na avaliação dos frutos para classificação da reação, identificou-se apenas um acesso de $C$. annuum como resistente (n²33 - Jalapeno), um de C. baccatum (n²22 - BGH 4176) e dois de C. chinense (n¹05 - Bode e $n^{\circ} 141$ - Pimenta $\left.{ }^{\circ} 2\right)$. Os demais acessos foram suscetíveis. Não houve correlação entre a reação de plântulas e frutos. As plântulas apresentaram menor quantidade de doença, em relação aos frutos. As progênies F3RC1 (3G, 4A, 4B, 4F, 4H, 5H, 6B, 6F, 8B, 8E, 8F, 9B, 9D, 9E, 9J, 10A, 13D, 13F, 14A, 14C, 16D, 16I, 17B, 19B) e as progênies F2RC2 (33F e 40G) não apresentaram lesões no estádio de frutos. Avançou-se geração nas progênies com reação de resistência em frutos, e suas populações F4RC1 e F3RC2 foram avaliadas no estádio de plântulas. Constatou-se variabilidade para a reação de antracnose nestas populações, com expressão de menor severidade e possibilidade de obter cultivares de pimentas e pimentões resistentes à antracnose. 


\title{
REACTION OF ACCESSES OF Capsicum spp. TO Colletotrichum sp., CAUSAL AGENT OF ANTHRACNOSE
}

\author{
Author: MÔNICA JULIANI ZAVAGLIA PEREIRA
} Adviser: Prof. Dr. NELSON SIDNEI MASSOLA JUNIOR

\section{SUMMARY}

Capsicum cultivation is an increasing activity in Brasil, and, in conseqüence, disease occurence is becoming more frequent. Anthracnose is the most common and desctructive disease of Capsicum in Brasil and other countries. Losses of $100 \%$ due to the disease are very frequent. Control of anthracnose using genetic resistance can be very suitable. The aim of this work was (i) to describe the reaction of 90 accesses of Capsicum annuum, 30 of C. baccatum, 16 of C. chinense and one of $C$. frutescens to anthracnose (ii) to establish the correlation of the reaction to anthracnose between seedlings and fruits of Capsicum and (iii) to evaluate the reaction to anthracnose of the progenies F3RC1 (C.annuum x C. chinense - resistant) x C. annuum and F2RC2 [(C. annuum x C. chinense - resistant) $\mathrm{x}$ C. annuum] $\mathrm{x}$ C. annuum. Four isolates of Colletotrichum sp. from pepper and one isolate from hot pepper were used for the inoculations, at a concentration of $1 \times 10^{6}$ spores $/ \mathrm{ml}$. After adjustment of the concentration of each suspension, they were mixed, in order to reduce possible effects of pathogenic variability among the isolates. The experimental design used was of completely randomized blocks with 20 and 15 replications for seedlings and green-ripe 
fruits inoculations, respectively. For the inoculation in seedlings, sugarcane juice at $5 \%$ was added to the spore suspensions, which were sprayed on the leaves of the seedlings at one-leaf stage. The seedlings were kept in a moist chamber for 24 hours before and 72 hours after the inoculation, at $26+/-2^{\circ} \mathrm{C}$ and 12 hours photoperiod, inside a growth chamber. To evaluate anthracnose on the inoculated plants, disease incidence and disease severity were considered. The last variable was rated based on a 1 to 5 scale, according to the amount of disease on the seedlings. The fruits were inoculated with a 20 $\mu \mathrm{l}$ droplet of the spore suspensions. After depositing the inoculum, the fruits were wounded with a needle at the inoculation point and kept at $24+/-2^{\circ} \mathrm{C}$, inside covered plastic containers. The evaluation was done based on lesions diameter, latent period, growth rate of lesions and incidence. The fruits evaluations were used for classifying the accesses reactions. Only one access of $C$. annuum ( $\mathrm{n}^{\circ} 233$ - Jalapeno), one of $C$. baccatum $\left(\mathrm{n}^{\circ} 222\right.$ - BGH 4176) and two of C. chinense $\left(\mathrm{n}^{\circ} 105\right.$ - Bode and $\mathrm{n}^{\circ} 141$ Pimenta $\mathrm{n}^{\circ} 2$ ) were considered resistant. The remaining accesses varied in degrees of susceptibility. Positive correlation between levels of disease in seedlings and fruits were not significant. The seedlings showed less amount of disease in relation to fruits. The progenies 3G, 4A, 4B, 4F, 4H, 5H, 6B, 6F, 8B, 8E, 8F, 9B, 9D, 9E, 9J, 10A, 13D, 13F, 14A, 14C, 16D, 16I, 17B, 19B (population F3RC1) and 33F and 40G (F2RC2) did not show lesions at the fruit stage. Generations were advanced in this population and populations F4RC2 and F3RC2 were evaluated at seedling stage. These seedlings showed variability for reaction to anthracnose, with lower severity, suggesting possibility of selection for resistance in Capsicum varieties. 


\section{INTRODUÇÃO}

As espécies de hortaliças do gênero Capsicum que constituem as pimentas e os pimentões, são usadas diariamente como condimento e alimento por mais de um quarto da população mundial.

Anualmente, no Brasil, são cultivados cerca de 13.000 hectares com as espécies de Capsicum, produzindo aproximadamente 280.000 toneladas de frutos para o consumo in natura de pimentão e para o processamento de molhos, conservas e outras formas de preparo de pimenta (Carvalho et al., 2003).

Notadamente, as pimentas e pimentões possuem elevada importância econômica na região Centro-Sul, em razão de seu cultivo e produtividade, a qual é muito dependente das condições climáticas e de doenças limitantes ao seu cultivo (Filgueira, 1983).

Muitos fungos, bactérias e vírus são patogênicos à cultura, causando redução no porte das plantas, podridões de raízes, caules e frutos e lesões em folhas (Capsicum, 2003).

A antracnose, causada por Colletotrichum sp., é a mais comum e destrutiva doença das solanáceas, especialmente no período de cultivo quente e úmido (Lobo Jr. et al., 2001) porém, como quase todos os cultivares brasileiros derivam do cultivar Cascadura, que é altamente suscetível à C. gloeosporioides, as variedades e híbridos comerciais de Capsicum não são resistentes à doença (Henz et al., 1993a).

A doença ocorre principalmente em frutos, causando podridões com lesões em forma de depressões circulares, de coloração escura, com diâmetro variável, de onde emerge a massa de conídios de coloração rosa-salmão (Kurozawa \& Pavan, 1997). Esta 
lesão deprecia o fruto, causando perdas diretas, reduzindo a qualidade dos frutos para o comércio, com conseqüente prejuízo ao produtor rural (Halfeld-Vieira et al., 2004).

Um dos métodos de controle de doenças de plantas é a utilização de variedades resistentes. Apesar da importância da antracnose, nenhum programa nacional de melhoramento tem se concentrado nesta doença (Henz et al., 1993a).

A atividade de agribussines envolvendo o gênero Capsicum demanda novos cultivares, tanto para o processamento como para o consumo in natura, com alta produtividade e qualidade de frutos, associado com resistência a maioria das doenças e pragas importantes (Carvalho et al., 2003).

Existem poucas informações a respeito da reação de pimentas e pimentões à antracnose das solanáceas. Postulou-se que alguns acessos da coleção de Capsicum da ESLAQ/USP poderiam ser fontes de resistência ao fungo. Progênies derivadas do programa de melhoramento de pimentas e pimentões envolvendo retrocuzamento de um cruzamento interespecífico entre $C$. annuum x $C$. chinense (PBC 932 resistente à antracnose) foram triadas na busca de identificar e selecionar materiais resistentes à este patógeno.

Os objetivos deste trabalho foram (i) caracterizar a reação à antracnose dos acessos da coleção de Capsicum spp. da ESALQ/USP; (ii) estabelecer a correlação de reação à antracnose entre plântulas e frutos de Capsicum e (iii) avaliar as linhagens derivadas de cruzamentos interespecíficos de $C$. annuum x $C$. chinense nas suas progênies do primeiro e segundo retrocruzamentos com a espécie C. annuum. 


\section{REVISÃO DE LITERATURA}

\subsection{Espécies do gênero Capsicum}

Pertencentes à família das Solanáceas, as espécies do gênero Capsicum são conhecidas como pimentas e pimentões. O centro de origem deste gênero encontra-se nas Américas, embora sejam atualmente cultivadas em regiões tropicais e temperadas (Casali \& Couto, 1984).

Historicamente, as pimentas parecem ter surgido a 7.000 anos A.C. na região do México Central (Pimentas Quentes, 2003), e sua distribuição pelo mundo ocorreu no século XVI por navegadores portugueses e espanhóis que procuravam um substituto para a escassa e valiosa pimenta-do-reino.

As espécies de pimentas mais cultivadas no Brasil e na América do Sul são Capsicum chinense, C. frutescens e C. baccatum. Contudo em outras regiões o cultivo de pimenta é baseado na espécie $C$. annuum, que também inclui o pimentão. Existe ainda as espécies selvagens e silvestres, com as quais há possibilidade de se efetuarem cruzamentos. São reconhecidas por especialistas 22 espécies selvagens de Capsicum, dentre as quais, as que se destacam no Brasil são C. buforum e C. schottianum (Casali \& Couto, 1984).

A espécie $C$. annuum é a mais cultivada e a que apresenta maior variabilidade. Pertencem a esta espécie os pimentões, as pimentas e poucos cultivares ornamentais. Suas flores são solitárias, a corola é branca, sem manchas na parte basal dos lóbulos, que são eretos. Conhecida como pimenta malagueta, C. frutescens possui flores que se formam em número de uma a cinco por nó, com pedicelo ereto e pequeno. A corola é verde-clara a branco-esverdeada, sem manchas. As pimentas mais pungentes do mundo encontram-se na espécie $C$. chinense, as quais possuem flores em número de duas a 
cinco, pedicelo ereto, pendente ou inclinado na antese, corola branca ou brancoesverdeada com lóbulos retos que não dobram nem possuem manchas na base. Dentro da espécie C. baccatum ocorrem duas variedades. As flores são normalmente solitárias, podendo apresentar duas por nó, com pedicelo pendente ou inclinado (var. pendulum tipo Dedo de Moça) e duas a cinco flores por nó e pedicelo ereto (var. baccatum). A corola é branca com lóbulos retos, com manchas amarelas ou amarelo-esverdeadas na base (Casali \& Couto, 1984).

\subsection{Produção e Comercialização}

No Brasil, anualmente, cerca de 12.000 hectares são cultivados com pimentões, com produção aproximada de 280.000 toneladas de frutos. Todos os estados brasileiros produzem esta solanácea, porém a maior produção está concentrada nos estados de São Paulo e Minas Gerais, que são responsáveis pelo plantio de 5.000 ha e produção de 120.000 toneladas. Somente o mercado de sementes de pimentão movimenta US\$ 1,5 milhão (Ribeiro \& Cruz, 2003).

A produtividade média da cultura da pimenta é de 4 a 10 toneladas por hectare (t/ha) e de pimentão é de 15 a 40 t/ha (Filgueira, 1983).

O volume comercializado de pimentão na CEAGESP-SP para o ano de 2000 foi de 35.079 toneladas e para o ano de 2003, até o mês de junho, a comercialização foi de 17.164 toneladas (Agrianual, 2004).

\subsection{Ocorrência de Colletotrichum sp. em Capsicum spp.}

Existem vários agentes causadores de doenças, como bactérias, fungos, nematóides e vírus que podem incidir sobre espécies do gênero Capsicum, dentre as mais comuns são citadas: Murcha-de-Phytophthora (Phytophthora capsici), Vírus (várias espécies), Oídio (Oidiopsis taurica), Antracnose (Colletotrichum gloeosporioides) e Mancha-bacteriana (Xanthomonas axonopodis pv. vesicatoria) (Kurozawa \& Pavan, 1997).

A doença em estudo neste trabalho é popularmente conhecida por antracnose, e tem como agente causal, descrito em literatura, Colletotrichum gloeosporioides Penz em 
sua forma imperfeita (fungo mitospórico, ordem Melanconiales) e Glomerella cingulata (Ston.) Splaud et Schr. em sua forma perfeita (Kurozawa \& Pavan, 1997).

Porém, de acordo com Rawal et al. (1983), a antracnose é uma doença causada por várias espécies de Colletotrichum. Em alguns países, a podridão de frutos causada por C. capsici é amplamente disseminada, capaz de causar perdas que variam entre 10 e 75\%. No Brasil, C. capsici é considerado como um fungo potencialmente quarentenário nas culturas da manga, mamão e pimentão (Felix et al., 2003). Além do $C$. gloeosporioides, também têm sido identificados C. acutatum, C. coccodes, C. dematium e G. cingulata infectando frutos de pimentão na Coreia (Park et al., 1991 e Oh et al., 1999) e C. capsici e G. cingulata em Taiwan (Oh et al., 1999).

Na Flórida, USA, o primeiro relato da ocorrência de antracnose, causada por $C$. gloeosporioides e C. coccodes foi realizado por McGovern (1995) em 1994. Foi observado severa podridão de frutos maduros em C. chinense, a qual variou de 25 a $50 \%$ de incidência.

No Brasil, Tozze Jr. et al. (2004) caracterizaram morfologica e molecularmente isolados de Colletotrichum obtidos de pimentão, pimenta e jiló. Os resultados obtidos indicam a presença de C. acutatum e C. gloeosporiodes causando a antracnose nas solanáceas no Brasil.

Sua importância é evidenciada em condições de clima quente e alta umidade, e períodos de alta pluviosidade, podendo afetar até 100\% dos frutos quando em alta pressão de inóculo (Kurozawa \& Pavan, 1997), sendo considerada a mais limitante e destrutiva doença nos cultivos de verão (Henz et al., 1993a).

A doença ocorre numa ampla distribuição geográfica, principalmente nas regiões tropicais e subtropicais quando a irrigação é feita por aspersão e/ou em condições de elevadas precipitações pluviométricas (Black et al., 1991). No Brasil, sua presença é evidenciada desde o Rio Grande do Sul até o Nordeste, e também nas áreas elevadas dos Estados de Minas Gerais e Goiás, afetando as culturas do pimentão, berinjela e jiló (Salgado \& Tokeshi, 1980).

O aparecimento dos sintomas pode ocorrer durante o desenvolvimento da cultura ou em pós-colheita (Black et al., 1991). As primeiras lesões são pequenas, 
aquosas e deprimidas que rapidamente se expandem, sem diâmetro definido, podendo muitas vezes, atingir as sementes e causar a sua destruição (Doolittle, 1953; Kurozawa \& Pavan, 1997). Damping-off de pré e pós emergência, necrose e manchas em folhas também são sintomas observados em algumas condições (Black et al., 1991). A liberação dos conídios (unicelulares, hialinos, ovóides, em acérvulos) ocorre somente com a presença de um filme de água, devido à presença de uma massa mucilaginosa que os envolve, aglutinando-os e inibindo a sua germinação. Após os frutos serem infectados, os esporos produzidos na superfície das manchas são lavados pela água ou por respingos da chuva e são disseminados dentro e entre culturas (Doolittle, 1953; Kurozawa \& Pavan, 1997). No que concerne ao cultivo in vitro, Yoon \& Park (2001) estudaram as condições ideais para a esporulação de C. gloeosporioides. Verificaram que as melhores condições ocorreram em meio BDA mantido a temperatura de $30^{\circ} \mathrm{C} \mathrm{e}$ 16 horas de iluminação. As condições ótimas de pós inoculação foram $30^{\circ} \mathrm{C}$ de temperatura, não influenciando o regime de luz no desenvolvimento dos sintomas.

O patógeno pode sobreviver em sementes infectadas, restos de cultura e em hospedeiros alternativos (Black et al., 1991). As sementes constituem-se na fonte de inóculo responsável pela introdução do patógeno em áreas indenes (Kurozawa \& Pavan, 1997).

Alguns estudos tem demonstrado que o fungo apresenta especialização quanto à espécie de solanácea, assim, isolados obtidos de pimentão não infectam o jiló (Kurozawa \& Pavan, 1997). Fernandes et al. (2002) estudaram a variabilidade patogênica de isolados de C. gloeosporioides por meio de inoculações cruzadas em frutos, com isolados de jiloeiro, pimentão e berinjela. Os resultados indicaram que isolados de jiloeiro apresentaram maior agressividade para frutos desta espécies e de berinjela. Os isolados de pimentão foram mais agressivos para a sua espécie e para berinjela, e os isolados de berinjela apresentaram menor agressividade para as três solanáceas. Deste modo, os autores concluíram que os isolados de C. gloeosporioides provenientes de jiloeiro, pimentão e beringela apresentam, em maior ou menor grau, adapatação para as espécies hospedeiras. Os sintomas induzidos por isolados do 
patógeno provenientes do seu respectivo hospedeiro foram mais severos do que quando inoculados em outros hospedeiros.

Em decorrência das severas perdas causadas por C. gloeosporioides na cultura do pimentão, Halfeld-Vieira et al. (2004) avaliaram, em condições de cultivo protegido, a incidência de antracnose no Estado de Roraima. Foram avaliados cinco híbridos de pimentão em oito etapas de colheitas, quantificando-se a incidência da doença em frutos. Os resultados apresentaram incidência variável entre 1,3\% (híbrido Amanda) e 6,1\% (híbrido Martha). A medida em que os frutos são colhidos há redução significativa do percentual de frutos com antracnose nas colheitas subsequentes, devido à redução da pressão de inóculo pelos frutos infectados removidos.

Rocha et al. (2004) também estudaram a incidência de antracnose ( $C$. gloeoporioides) em pimentão em condições de campo. Os primeiros frutos com sintomas somente foram observados a partir de novembro, com a elevação da temperatura e da precipitação. As cultivares Magda, Cascadura Itaipu e Magali R apresentaram, respectivamente, 50\%, 50\% e 40\% de frutos com antracnose.

Na Virginia, USA, a ocorrência de antracnose, causada por C. gloeosporiodes têm causado perdas variáveis entre 35\% e 70\% nos campos de produção de pimentas e pimentões (Alexander \& Marvel, 2002).

\subsection{Análise da resistência}

Qing et al. (2002) desenvolveram um trabalho para estudar a herança da resistência à antracnose do pimentão, na Ásia, causada por C. capsici, realizando cruzamentos entre a variedade resistente '83-168'e o cultivar suscetível 'KKU Cluster'. Com a população F1, os autores realizaram autofecundação e retrocruzamentos com as linhagens parentais. A inoculação foi realizada com concentração de $10^{6}$ esporos/ml pela deposição de uma gota de $6 \mu \mathrm{l}$ na superfície dos frutos com posterior ferimento usando uma agulha. A percentagem de frutos infectados foi de 100\% para ‘KKU - Cluster’ e 24\% para '83-168’, aos 4 dias após a inoculação (DAI), aumentando para $60 \%$ e 91,1\% aos 5 e 7 DAI, respectivamente em '83-168'. O critério de número de frutos infectados aos 4 DAI foi utilizado para determinar a herança da resistência à 
antracnose. Todas as plantas F1 de ambos cruzamentos apresentaram resistência, indicando que a resistência derivada da variedade '83-168' é provavelmente dominante. Na população F2, a segregação foi na proporção de 3:1 (resistentes : suscetíveis). O cultivar parental suscetível 'KKU - Cluster' alcançou 100\% de incidência aos 4 DAI, enquanto que a resistente '83-168' apresentou 24\%, 60\% e 91,1\% de incidência, aos 4, 5 e 7 DAI, respectivamente. Deste modo, os autores chegaram a conclusão de que a resistência na linhagem '83-168' expressa-se pelo atraso da infecção dos frutos. A análise genética indicou que apenas um gene dominante foi responsável pela resistência avaliada aos 4 DAI.

Trabalho semelhante foi desenvolvido por Park et al. (1990) utilizando as linhagens de pimentão PI 244670 (suscetível à C. dematium) e Chungryong (resistente) considerando a média do diâmetro das lesões nas populações F1, F2 e RC (retrocruzamento). As médias das gerações F1 e F2 foram intermediárias, sugerindo ser a resistência parcialmente dominante.

Cheema et al. (1984a) estudaram a herança da resistência à antracnose ( $C$. capsici) em plântulas de pimenta, sendo utilizadas três parentais resistentes (307-10, 314-1 e 344-9) e dois suscetíveis (292-2 e 310-3), onde seis gerações derivadas dos cinco cruzamentos foram avaliados. Os autores concluíram que a resistência à antracnose apresentou-se de natureza poligênica, governada por genes aditivos e nãoaditivos. Ahmed et al. (1991) também trabalharam com pimentas, obtendo seis gerações originárias de cruzamentos entre o cultivar suscetível Kolascai E-14 e o resistente Perennial para avaliação da reação ao C. capsici. As médias de percentagem de doença na população F1 (suscetível x resistente) foi intermediária, indicando a predominância da ação de genes aditivos governando a resistência, concordando com o estudo desenvolvido por Cheema et al. (1984a). A ampla gama de tipos de variações nas gerações F2, B1 (F1 x Kolascai E-14) e B2 (F1 x Perennial) indica que a resistência à antracnose deve ser de controle poligênico.

A bioquímica da resistência à podridão de frutos causada por C. capsici foi estudada por Hegde \& Anahosur (2001) em 52 populações de pimenta em condições naturais na Índia. As pimentas LCA-301, LCA-324, K-1 e Byadgi Kaddi foram 
resistentes. Estes autores verificaram que os frutos resistentes continham elevadas concentrações de capsacinóides e ácido ascórbico, e baixas quantidades de açúcares em comparação às testemunhas suscetíveis. Jeyalakshmi et al. (1999) observou que o conteúdo de capsacinóides, ácido ascórbico e proteínas foi máximo em variedades resistentes e mínimo em variedades suscetíveis, concordando com os dados obtidos por Hegde \& Anahosur (2001).

Cheema et al. (1984b) também estudaram a bioquímica da resistência de cinco linhagens de pimenta (três resistentes - 307-10, 314-1 e 344-9 e duas suscetíveis - 292-2 e 310-3) à C. capsici, avaliando as concentrações dos constituintes fenólicos e a relação destes com a resistência dos materiais. Os autores concluíram que as substâncias fenólicas das diferentes linhagens foram variáveis, porém sem apresentarem nenhuma relação com a sua resistência.

O desenvolvimento de antracnose (C. gloeosporioides) em frutos verdes e maduros de pimentão foi estudado por Kim et al. (1999) utilizando-se o isolado KG 13. Foi verificado que a inoculação de frutos verdes com e sem ferimento ocasionou lesões típicas deprimidas de antracnose, enquanto que os frutos maduros com e sem ferimento apresentaram apenas uma pequena descoloração marrom no ponto de infecção. Os autores acreditam que esta diferença de infecção pode ser devida à espessura da parede cuticular dos frutos que possui importante função na prevenção da infecção e colonização pelo fungo. Esta diferença de infecção também pode ser explicada pelas diferenças existentes nas propriedades bioquímicas dos frutos de pimentão. Ko (1986) ${ }^{1}$ citado por Kim et al. (1999) demonstrou que frutos verdes possuem elevada atividade de peroxidases e polifenol-oxidades em relação aos frutos vermelhos, mas baixos níveis de fenólicos totais, aminoácidos e carboidratos, os quais tem sido relatados na resistência do hospedeiro.

Manandhar et al. (1995), estudaram a resposta de linhagens de pimentão ao desenvolvimento de C. gloesporioides Foi verificado maior incidência de antracnose em frutos mergulhados no clorofórmio do que naqueles mergulhados em água. Quando mergulhados no clorofórmio, ocorre a retirada da camada cerosa dos frutos,

\footnotetext{
${ }^{1}$ - Ko, Y. H. The physiological and biochemical characteristics of Colletotrichum gloeosporioides Penz. and the host plant, Capsicum annuum L. PhD. Dissertation, Korea University, Seoul, Korea. 1986.
} 
evidenciando ser este um mecanismo de defesa, que dificulta a penetração e posterior colonização do patógeno.

Oh et al. (1999) utilizando isolado KG 13, que foi o mesmo isolado utilizado por Kim et al., (1999), estudaram o efeito da cerosidade da epiderme dos frutos verdes e maduros na infecção de C. gloeosporioides e sua relação entre estádios de desenvolvimento e a ocorrência de sintomas. Os autores encontraram diferença significativa no diâmetro de lesões e na produção de conídios entre frutos verdes e maduros quando estes não foram mergulhados no clorofórmio. Quando mergulhados no clorofórmio, não houve diferença entre frutos verdes e maduros. Quanto aos estádios de desenvolvimento dos frutos, foram avaliados frutos com $1 / 4,1 / 2,3 / 4$ do tamanho normal, frutos verdes desenvolvidos e frutos vermelhos desenvolvidos. Quanto mais precoce for a inoculação, maior o diâmetro de lesão e a esporulação. Foi possível verificar também que a cera da parede cuticular se desenvolve com a maturação dos frutos. Estes resultados evidenciaram que a cerosidade dos frutos seja um importante mecanismo de defesa na infecção dos frutos por C. gloeosporioides, concordando com os resultados obtidos por Manandhar et al. (1995)

Em trabalho realizado por Gniffke (2003) foi verificada a resistência de pimentão para as diferentes espécies de Colletotrichum. O autor utilizou isolados agressivos de C. acutatum, C. gloesporioides e C. capsici para realizar a inoculação em frutos verdes de seis acessos de pimentão previamente identificados como resistentes à antracnose. Foram considerados resistentes os frutos que apresentaram diâmetro de lesão de menor que $4 \mathrm{~mm}$ aos 5 dias após a inoculação. Pode-se observar que C. acutatum, na maioria dos casos, apresentou lesões maiores em comparação às outras espécies, sugerindo que a resistência às três espécies fúngicas testadas são independentes. Com base neste critério de avaliação da reação, a maioria dos acessos foi resistente.

Santos et al. (2004) estudaram a severidade de antracnose em função do estádio fisiológico de maturação dos frutos e das espécies de Capsicum. Mediu-se o comprimento das lesões, no maior diâmetro, aos 4 e 8 dias após a inoculação. $\mathrm{Na}$ maioria das linhagens, o comprimento de lesão nos frutos verdes foi menor que nos frutos maduros; e em frutos verdes, 15\% dos genótipos foi resistente, 30\% intermediário 
e 55\% suscetível. Em frutos maduros, observaram que 30\% foram resistentes, $25 \%$ intermediários e 45\% suscetíveis. Foram considerados resistentes os frutos com até 13,3 mm de comprimento de lesão quando verdes e 18,1 mm de comprimento de lesão quando maduros. As linhagens de C. frutescens (CNPH 3503 e 3746) foram as mais resistentes quando verdes, e quando maduros as linhagens 3755 (C. baccatum) e 3777, 3761, 3503 e 3784a (C. chinense) foram as mais resistentes.

Uma severa forma de antracnose apareceu em Ohio e em outros estados dos EUA, ocorrendo em frutos maduros e imaturos, causando perdas de até $100 \%$ em pimentas. Ivey et al. (2004) isolaram o agente causal e identificaram, baseado na morfologia e em ensaios de PCR, como sendo C. acutatum. Foi verificada a reação de cultivares à doença em ensaios de campo. Todos os cultivares foram suscetíveis ao patógeno, em maior ou menor grau.

A reação de 52 linhagens de Capsicum spp. quanto à severidade de $C$. gloeosporioides em frutos foi caracterizada por Henz et al. (1993a). Foi verificado que apenas três linhagens comportaram-se com resistentes, 18 como intermediárias e 31 como suscetíveis, pela análise de Cluster. Nesta avaliação, o diâmetro de lesão variou de 0,11 mm (CNPH 2686 e AVRDC 17) a 1,93 mm (CNPH 2811) aos 4 dias após a inoculação. Dentre os suscetíveis, encontram-se os cultivares Agronômico 10G e Cascadura Ikeda, que foram muito populares entre os produtores brasileiros. Após este ensaio, os autores selecionaram cinco linhagens (AVRDC 13, AVRDC 16, CNPH 2689, CNPH 2727 e CNPH 2682) para avaliação de inoculação em dois diferentes estádios de desenvolvimento dos frutos. No estádio de fruto verde, todos foram altamente resistentes à antracnose e no estádio de frutos maduros, apenas a linhagem (CNPH 2689) foi suscetível. As demais foram considerados parcialmente resistentes, com diâmetro de lesão entre 0,56 a 0,96 cm, em avaliação aos 4 dias após a inoculação.

Em outro ensaio, Henz et al. (1993b) avaliaram 39 acessos de Capsicum chinense quanto à resistência do fruto à C. gloeosporioides. Destes, 26 acessos foram avaliados em dois estádios de maturação. Foi avaliado o diâmetro de lesões aos 5 dias após a inoculação, onde os acessos CEN 027, CEN 015-1, CEN 026, CNPH 143, CNPH 148, 275 e CEN 037 destacaram-se como altamente resistentes no estádio de fruto 
maduro com alteração de cor e CEN 015-2, 275 e CEN 019 em frutos maduros sem alteração de cor.

Dando continuidade a seus ensaios, Henz et al. (1994) avaliaram 24 e 46 acessos de Capsicum spp. em dois experimentos, em dois estádios de maturação quanto à reação à C. gloeosporioides. A avaliação foi realizada cinco dias após a inoculação medindo-se o diâmetro médio das lesões. Dez foram considerados como altamente resistentes no primeiro e seis no segundo experimento, sem diferenças quanto aos estádios de maturação dos frutos.

Choi et al. (1990) fizeram inoculações de C. gloeosporioides em frutos verdes para verificar a resistência de pimentão à antracnose. Das 89 introduções testadas, apenas 6 apresentaram resistência.

Jeyalakshmi \& Seetharaman (1998) avaliando a reação de acessos de pimenta à antracnose nos frutos observaram que apenas um acesso (CA87-4), dos 40 testados, foi altamente resistente, 7 foram resistentes, 19 foram moderadamente suscetíveis e 13 foram suscetíveis. Contudo Roy et al. (1998) avaliaram 24 acessos de C. annuum, também quanto à infecção em frutos, e não encontraram nenhuma fonte de resistência na coleção de pimentas e pimentões.

A caracterização de sete cultivares de Capsicum annuum ao patógeno $C$. acutatum foi realizada por Kaur et al. (1983). Foi verificado que cinco cultivares (Puss Jwala, Jullundri, S 118-2-1, Perennial e Hatvani) foram altamente suscetíveis, enquanto que JED 4-2-2 e Lorai foram consideradas resistentes.

Lobo Jr. et al. (2001) avaliaram 63 acessos de Capsicum spp. quanto à resistência à antracnose. A inoculação foi realizada em frutos e apenas os acessos CNPH 56 e CNPH 143 (C. annuum), CNPH 599, CNPH 0600, CNPH 3264 e CNPH 3266 (C. chinense) não apresentaram lesões, sendo considerados imunes ao patógeno.

Rawal et al. (1983) caracterizaram 450 linhagens de Capsicum annum quanto à reação ao C. capsici, durante o período de 1978 a 1982. O campo de crescimento da cultura foi pulverizado uma vez, com a suspensão de esporos do fungo, no estádio de frutificação. Foi avaliada a ocorrência da doença nas folhas e nos frutos. Pode-se concluir, com o estudo, que apenas duas linhagens foram resistentes em folhas e em 
frutos. Uma linhagem apresentou resistência à infecção nos frutos, porém com manifestação de sintomas em folhas. Três linhagens apresentaram completa reação de resistência nas folhas, mas comportaram-se como suscetíveis nos frutos. Não houve correlação entre a ocorrência da doença na fase vegetativa em relação aos frutos.

A infecção de plantas de pimentão (C. annuum) por C. coccodes foi avaliada por Hong et al. (2001) nos estádios de duas e oito folhas, causando lesões suscetíveis e resistentes 96 horas após inoculação, respectivamente. Os dados demonstraram que no estádio de duas folhas houve desenvolvimento de sintomas progressivos, em contraste com a ocorrência de manchas localizadas necróticas no estádio de oito folhas. A oclusão de material anamorfo nos vasos do xilema, agregação de fibrilas nos espaços intercelulares e deposição de corpos de proteínas encontrados nas plantas adultas podem ser respostas e mecanismos de resistência à colonização do patógeno.

No estádio de plântulas, Suhardi (1991) avaliou 17 variedades de Capsicum spp. quanto à resistência à antracnose, causada por C. gloeosporioides. Estas variedades foram aspergidas com uma suspensão de $10^{5}$ esporos/ml e mantidas em câmara úmida durante 48 horas. A maioria apresentou suscetibilidade à antracnose, sendo que apenas um (Hot Beauty) foi moderadamente resistente e dois (Pip e Keriting Basar) foram resistentes.

Hong \& Hwang (1998) estudando a influência da densidade do inóculo, duração do período de molhamento, idade da planta, métodos de inoculação e resistência de cultivares no desenvolvimento de $C$. coccodes em plantas de pimentão em condições controladas. Verificaram que os sintomas de antracnose foram potencializados quando a concentração do inóculo foi aumentada de $10^{3}$ para $10^{6}$ conídios/ml. Geralmente, com o aumento da concentração de inóculo, aumentaram os sintomas da doença. A severidade da doença aumentou com o aumento da duração do molhamento de 0 para 60 horas. Com 48 horas de molhamento e densidade de inóculo de $10^{6}$ conídios/ml ocorreu o pico de desfolhamento e sintomas de necrose em plântulas de C. annuum. Quanto a idade da planta, foram avaliados plantas nos estádios de duas, quatro, oito folhas e primeira ramificação. Todos os cultivares de pimentão apresentaram aumento de resistência à antracnose com o aumento da idade das plantas. 


\section{MATERIAL E MÉTODOS}

\subsection{Local}

O experimento foi conduzido na área experimental do Departamento de Produção Vegetal e do Departamento de Entomologia, Fitopatologia e Zoologia Agrícola, setor de Fitopatologia, da Escola Superior de Agricultura “Luiz de Queiroz”ESALQ-USP, localizada no município de Piracicaba - SP.

\subsection{Coleção de acessos do Banco de Germoplasma de Capsicum spp. da ESALQ/USP}

Os acessos de Capsicum spp. caracterizados neste trabalho estão relacionados na Tabela 1. Estes materiais foram cedidos pelo Prof. Dr. Cyro Paulino da Costa do Departamento de Produção Vegetal, ESALQ/USP, para triagem da reação à antracnose das solanáceas.

Avaliou-se linhagens do programa de melhoramento envolvendo cruzamentos interespecífico de $C$. annuum x $C$. chinense. A fonte de resistência à antracnose utilizada no cruzamento foi a linhagem PCB 932 de C. chinense, resistente à Colletotrichum capsici, C. gloeosporioides e C. acutatum (Gniffke, 2003). Trata-se de uma pimenta, com fruto de forma cordiforme (forma de pião ou coração), de coloração vermelha e altamente pungente. Esta linhagem foi utilizada como progenitora masculina nos cruzamentos, utilizando a progênie F6 do cruzamento entre Rienger X Myr 29 de $C$. annuum como parental feminino. As progênies de pimentão (C. annuum) são homozigotas para resistência ao PeYMV (Pepper yellow mosaic virus) e a Phytophthora capsici. 
O primeiro retrocruzamento recorrente para a espécie $C$. annuum foi obtido a partir do cruzamento da progênie F4 originaria do cruzamento entre HV-12 x 609, descrito por Blat (2004) como resistente ao oídio e ao PeYMV, usando como parental masculino o F1 descrito anteriormente.

Obteve-se a geração F1 do primeiro retrocruzamento e avançou suas gerações F2RC1 e F3RC2. As progênies F3RC1 foram numeradas de 1 a 19 e testadas quanto à resistência à antracnose em frutos. A geração F4RC1 obtida do avanço de geração foi avaliadas quando à reação de antracnose em plântulas.

O segundo retrocruzamento para C. annuum foi realizado do cruzamento entre várias progênies F3 derivadas do híbrido Dom Camilo (Seminis - SVS do Brasil Sementes Ltda) com as progênies F1RC1. Avançou-se a geração F1RC2 para obter a geração F2RC2 que constituíram as progênies numeradas de 20 a 40 para o teste de reação à antracnose neste trabalho. A geração F3RC2 obtida do avanço de geração foi avaliada quanto à ocorrência de antracnose em plântulas.

A semeadura, para inoculação em plântulas, foi realizada em bandejas de 288 células. Quando as plântulas apresentavam o primeiro par de folhas verdadeiras desenvolvido, foi realizado o transplante para bandejas de 200 células.

Para a inoculação nos frutos, os acessos foram semeados em bandejas de 288 células e, com um mês de idade, as mudas foram transplantadas para vasos e cultivadas até a fase reprodutiva. Cada acesso foi transplantado para dois vasos, totalizando cinco plantas por vaso, a fim de se conseguir 15 frutos verdes desenvolvidos, com idade semelhante, no momento da inoculação.

\subsection{Preparação do inóculo}

Os isolados de Colletotrichum sp. utilizados no ensaio foram PI 03, PI 1709, Cl $2868^{1}$ e $\mathrm{Cl} 3105^{1}$ de pimentão e PA 03 de pimenta. Os isolados foram transferidos do tubo de ensaio, onde estavam conservados em óleo mineral, para placas de Petri contendo meio BDA (batata dextrose ágar), onde permaneceram até formar colônia (aproximadamente 1 semana). Após, foram transferidos para placas de Petri contendo

\footnotetext{
${ }^{1}$ - Isolados cedidos pela Sakata Seeds Sudamérica.
} 
meio de aveia e incubados a $25^{\circ} \mathrm{C}$, sob iluminação contínua, para favorecer a esporulação (Pereira, 1995).

A suspensão de esporos foi preparada minutos antes de cada inoculação com concentração de 1 x $10^{6}$ conídios/ml. Foi adicionado à suspensão 1 gota de Tween 20 para cada $100 \mathrm{ml}$ de água, a fim de evitar o agrupamento dos esporos. Na inoculação em plântulas, foi adicionado 5\% de caldo de cana na suspensão, como fonte de energia ao patógeno.

\subsection{Inoculações}

Para todas as inoculações, as suspensões de esporos de cada um dos cinco isolados mencionados no item 3.3 foram ajustadas, separadamente, para cerca de 1 x $10^{6}$ conídios/ml (Kim et al., 1999; Qing et al., 2002) e misturadas, visando eliminar possíveis efeitos decorrentes da variabilidade e possível adaptação patogênica do fungo.

\subsubsection{Plântulas}

Foram realizados testes preliminares para definir a metodologia de inoculação nas plântulas. No primeiro teste preliminar, as plântulas foram inoculadas e mantidas em câmara úmida durante 24 horas após a inoculação, utilizando-se as variedades de pimentão Dagmar e pimenta Dedo de Moça (C. baccatum), ambas suscetíveis à antracnose. Os tratamentos utilizados foram: T1 - testemunha não inoculada, T2 suspensão de esporos e T3 - suspensão de esporos + 5\% de caldo de cana. Após a câmara úmida, as plântulas foram mantidas em casa de vegetação. Apenas uma plântula da variedade Dagmar do tratamento T3 apresentou lesão, da qual foi reisolado o fungo. Os demais tratamentos não apresentaram lesões nas plântulas. Partindo deste indicativo, foi montado o segundo teste preliminar, com a variedade Dagmar, que constou de T1 testemunha não inoculada e T2 - suspensão de esporos + 5\% de caldo de cana, porém, as plântulas foram mantidas em câmara úmida durante 24 horas antes da inoculação e 72 horas após a inoculação. Em seguida, as plântulas permaneceram na sala climatizada onde foi realizada a câmara úmida, com temperatura de $26+/-2^{\circ} \mathrm{C}$. Neste teste, $100 \%$ das plântulas apresentaram lesões, das quais foi reisolado o fungo. Este teste foi repetido 
duas vezes, obtendo-se o mesmo resultado, estando assim, definida a metodologia de inoculação em plântulas.

De acordo com os dados obtidos nos teste preliminares, os acessos da coleção de Capsicum foram mantidos em câmara úmida durante 24 horas antes da inoculação e 72 horas após a inoculação. O ensaio foi instalado em câmara climatizada com temperatura de $26+/-2^{\circ} \mathrm{C}$ e fotoperíodo de 12 horas.

A inoculação nas plântulas foi realizada com a pulverização da suspensão de esporos (descrita no item 3.2) sobre as mesmas, até o ponto de escorrimento, quando estas apresentavam o primeiro par de folhas verdadeiras completamente expandido, de maneira semelhante à utilizada por Fernandes et al. (2002).

Foram testados 104 acessos, dentre C. annuum, C. baccatum e C. chinense. O único acesso de $C$. frutescens não fez parte do ensaio por falta de sementes. Os ensaios foram conduzidos duas vezes, em épocas distintas, sendo que na segunda vez foram utilizados 46 acessos, escolhidos com base nos resultados de suas reações no primeiro experimento. Foram testados também as progênies oriundas do avanço de geração das populações F3RC1 e F2RC2, caracterizadas nos frutos, denominadas F4RC1 e F2RC3, respectivamente.

Para cada acesso testado, 20 plântulas foram inoculadas com a suspensão de esporos e 10 foram inoculadas com água destilada esterilizada. Estas últimas serviram como testemunhas.

\subsubsection{Frutos}

Os frutos foram colhidos verdes e posteriormente desinfestados superficialmente em álcool 70\% durante dois minutos, hipoclorito de sódio 0,5\% por dois minutos e então lavados em água destilada esterilizada por um minuto. Após, foram acondicionados em bandejas de polietileno de 37x26x12 cm, colocando-se 15 frutos por bandeja. A metodologia de inoculação em frutos é conhecida na literatura e utilizada por vários autores (Henz et al., 1994; Kim et al., 1999; Lobo Jr. et al., 2001; Yoon \& Park, 2001; Gniffke, 2003; Santos et al., 2004). Consistiu em colocar uma gota de $20 \mu \mathrm{l}$ da suspensão de esporos sobre o fruto, na região mediana. Com o uso de uma agulha 
entomológica, foi realizado um ferimento abaixo da gota. Algodão umedecido em água destilada esterilizada foi colocado nos bordos das bandejas, as quais foram cobertas com plástico a fim de estabelecer uma câmara úmida. Os frutos foram mantidos nesta câmara durante todo o período de avaliação, com a finalidade de manter condições favoráveis à manifestação da doença. O ensaio foi instalado no laboratório de Micologia da ESALQ/USP, com temperatura de $24+/-2^{\circ} \mathrm{C}$ e fotoperíodo de aproximadamente 12 horas..

Foram testados 90 acessos de $C$. annuum, 30 de $C$. baccatum, 16 de $C$. chinense e 1 de $C$. frutescens para inoculações em plântulas e frutos. Estes ensaios foram conduzidos duas vezes, em épocas distintas, sendo que no segundo experimento foram utilizados 35 acessos, escolhidos com base nos resultados do primeiro experimento.

Foram avaliadas quanto a ocorrência de antracnose nos frutos, as progênies 1 a 19 da geração F3RC1 e as progênies 20 a 40 da geração F2RC2, com número de plantas variável entre 1 e 11, totalizando 260 tratamentos.

\subsection{Critérios de avaliações das reações do hospedeiro à antracnose}

As avaliações da reação dos acessos inoculadas foram realizadas com base na incidência e severidade da doença na fase de plântulas e frutos. Para avaliar a incidência na fase de plântulas, contou-se o número de plântulas com sintomas de folhas necrosadas, murcha, morte do meristema apical e morte da plântula. A severidade foi avaliada com base em uma escala visual de severidade da doença, com notas variando de 1 a 5 (1 - sem sintomas; 2 - traços a 10\% da plântula com sintomas; 3 - 11 a $25 \%$ da plântula com sintomas; 4 - 26 a 50\% da plântula com sintomas e 5 - acima de 50\% da plântula com sintomas e morte). Foram realizadas sete avaliações em um intervalo de 19 dias, sendo a primeira avaliação realizada aos três dias após a inoculação (DAI), quando foi retirada a câmara úmida.

Para as avaliações nos frutos, foram considerados a incidência (\% de frutos infectados), diâmetro de lesões, velocidade de crescimento de lesões e período latente. A velocidade de crescimento das lesões foi obtida por meio de mensurações sucessivas do diâmetro dos mesmos. O período latente foi considerado como o número de dias até a 
esporulação do patógeno sobre os frutos inoculados. Esta esporulação foi observada com o auxílio de uma lupa de aumento 10x. Foram realizadas cinco avaliações em um intervalo de 11 dias, com a primeira avaliação realizada aos três dias após inoculação (DAI).

\subsection{Delineamento experimental e análise estatística dos resultados}

O delineamento experimental utilizado foi inteiramente casualizado com 20 repetições para a inoculação em plântulas e 15 repetições para a inoculação em frutos. Os ensaios foram conduzidos duas vezes, em épocas distintas.

Para classificação dos genótipos em classes de resistência, foi utilizado o teste de Cluster (Henz et al., 1993a) aplicado sobre os resultados obtidos com as avaliações nos frutos. A existência de relação entre o comportamento de plântulas e frutos, em relação à antracnose, foi verificada com análise de correlação. 


\section{RESULTADOS E DISCUSSÃO}

\subsection{Reação de acessos de Capsicum spp. à antracnose, em plântulas}

As plântulas inoculadas com água destilada esterilizada, que serviram como testemunhas, não apresentaram sintomas da doença.

No primeiro experimento, aos 3 DAI, 66,7\% dos acessos de C. annuum apresentaram lesão, com severidade variando de 1,05 (n³ - \#138, n4 - \#36, n 34 BGH 3889, n¹32 - Pimenta Doce IH 1744, n²31 - ICA \#64 e n³41 - Arivivi \#142 ) a 3,40 (n²27 - BGH 5122) na escala de notas. Os demais acessos (33,3\%) não apresentaram lesão nesta avaliação. Na avaliação aos 10 DAI, os acessos n $14-$ BGH 3058, n²7 - BGH 3756, n³0 - BGH 3758, n³1 - BGH 3881, n³3 - BGH 3888, n 40 - Catarino Cascabel, n 44 - CNPH 144, n56 - ICA \# 131, nº67 - Mulato Dulce, n² 214 - Arivivi \#261 e n³00 - \#17 não apresentaram lesões. O restante 85,9\% apresentaram severidade de doença variável entre 1,05 (n9 - Ano Todo, n²6 - BGH 3714, nº61 Jalapeno (Cica)\#1, n¹32 - Pimenta Doce IH 1744 e n²31 - ICA \#64) e 4,30 (n²27 BGH 5122). Na avaliação aos 19 DAI, a maioria dos acessos (94,87\%) apresentavam lesões, com exceção dos números n¹4 - BGH 3058, n 40 - Catarino Cascabel, n56 ICA 131 e n²14 - Arivivi \# 261 sem lesões. Convém destacar que o nº 7 - Agronômico 10G, n³8 - Calahora e n²27 - BGH 5122 apresentaram as maiores severidades da doença, com valores de 3,80; 3,75 e 4,32, respectivamente (Tabela 2).

Hong et al. (2001) estudaram a infecção de C. annuum à antracnose em plântulas nos estádios de duas e oito folhas. Verificou-se que as plântulas inoculadas no estádio de duas folhas foram suscetíveis em relação às inoculadas com oito folhas, que foram resistentes. Neste ensaio, as plântulas foram inoculadas no estádio de uma folha, o qual, de acordo com Hong et al. (2001) foi suscetível à infecção. 
A incidência de antracnose em C. annuum (Tabela 2) variou de 0 a 89,5\% aos 3 DAI. Apenas um acesso apresentou 100\% de incidência aos 10 DAI (n³8 Calahora), enquanto que a maioria não apresentaram doença. Contudo, na última data de avaliação, aos 19 DAI, apenas quatro acessos (n¹4 - BGH 3058, n40 - Catarino Cascabel, n56 - ICA \#131 e n²41 - Arivivi \#261) não desenvolveram sintomas da doença, enquanto que dois acessos (n³8 - Calahora e n²11 Aji Rojo \#258) apresentaram $100 \%$ de incidência.

Com relação aos acessos de C. baccatum, no primeiro experimento, na avaliação aos 3 DAI, a maioria (73,9\%) apresentou sintomas de antracnose em folhas ou hastes, cuja severidade variou numa amplitude de 1,05 (n²36 - Pimenta e n²38 Pimenta Branca Piranga) a 1,85 (n²03 - Aji \#286). Na avaliação realizada aos 10 DAI, apenas dois acessos se destacaram sem lesões, sendo eles o n²20 - BGH 1675 e o n²39 - Pimenta Cambuci, os demais apresentaram severidade de doença até 2,50 (n²03 - Aji \#286). Aos 19 DAI todos apresentavam lesões, com severidade variando de 1,05 (n²38 - Pimenta Branca Piranga) a 2,55 (n²03 - Aji \#286) (Tabela 2).

Dos três acessos de $C$. chinense avaliados, dois deles se destacaram $\left(n^{\circ} 122-\right.$ Pimenta e n¹35 - Pimenta doce IH-1758), apresentando severidade de doença menores de 2,0. O acesso $n^{\circ} 145$ - PI 152225, anteriormente identificado com um dos mais suscetíveis, foi severamente afetado, apresentando na avaliação aos 3, 10 e 19 DAI severidades de doença de 1,5; 3,8 e 4,5 na escala de notas, e incidência de 50, 100 e 100\% respectivamente. Para os demais, a incidência não ultrapassou o valor de 35\% nas datas de avaliação (Tabela 2).

No segundo experimento, de modo geral, os acessos de Capsicum, indiferente da espécie, apresentaram valores mais elevados de severidade de doença e incidência em relação ao primeiro experimento (Tabela 2). Este comportamento mostrou que há dificuldade de se reproduzir, com precisão, os resultados de inoculações em plântulas.

Entretanto, comparando-se as severidades de doença, com base na escala de notas, e a incidência nos materiais, pode-se verificar que, de modo geral, aqueles materiais com maior severidade de doença também apresentaram maior incidência, com 
a maioria de suas plântulas infectadas, nos dois experimentos. A recíproca também é verdadeira (Tabela 2).

Com base nos resultados das reações da coleção de Capsicum, os acessos n²27 - BGH 5122 de C. annuum e n¹45 - PI 152225 de C. chinense foram utilizados nos dois experimentos como padrões de suscetibilidade. Estes acessos apresentaram comportamento semelhante nas avaliações, com severidade de doença de 3,55 e 4,32, respectivamente, para o primeiro e segundo experimento no acesso n²27 - BGH 5122 e de 4,50 e 4,20, respectivamente para o acesso n¹45 - PI 152225, aos 19 DAI.

As progênies provenientes dos retrocruzamentos do cruzamento original entre C. annuum x C. chinense que não apresentaram lesões nas avaliações de frutos (Tabela 6) foram testadas novamente para verificar a sua reação no estádio de plântulas (Tabela 3). Utilizaram-se como testemunhas suscetível e resistente, respectivamente, os acessos n¹45 - PI 152225 e PBC 932 (Figura 1). O acesso n¹45 - PI 152225 apresentou a maior severidade de doença em todas as avaliações, com notas 1,7; 3,9 e 4,3 aos 3, 10 e 19 DAI, respectivamente. Já a pimenta PBC 932 (C. chinense) não apresentou lesões em nenhuma das avaliações. As demais progênies apresentaram lesões, porém em severidades baixas (nota menor que 2,5). Apenas a progênie 4F apresentou valores elevados, atingindo severidade de 3,5 na última avaliação (19 DAI), com 100\% de incidência. Pode-se afirmar que estas progênies ainda estão segregando para a resistência à antracnose. As incidência de antracnose nestes materiais foi muito variável, oscilando de 0\% (progênie 3J, 4B e 14C) até 61\% (progênie 8E).

Suhardi (1991) avaliou a reação de variedades de Capsicum spp. quanto à ocorrência de antracnose em plântulas. A maioria das variedades testadas foi suscetível, apenas duas foram consideradas resistentes em plântulas.

A testemunha (n¹45 - PI 152225) utilizada como parâmetro de suscetibilidade nas avaliações em plântulas mostrou-se altamente suscetível em todas as avaliações. O parâmetro de comparação resistente PBC 932 apresentou-se como resistente, comprovando a eficiência do método de inoculação. 


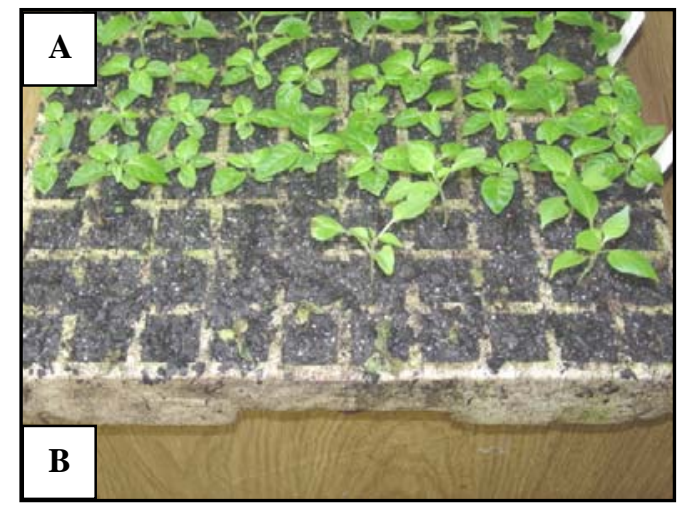

Figura 1 - Reação de acessos resistente versus suscetível de $C$. chinense à antracnose. Em (A) a testemunha resistente PBC 932 e em (B) a testemunha suscetível n¹45 - 152225, aos 19 dias após a inoculação

\subsection{Reação de acessos de Capsicum spp. à antracnose, em frutos}

A reação, expressa em diâmetro de lesões, foi variável no tempo (Tabela 4). Aos 3 DAI nenhum dos acessos apresentou diâmetro de lesão maior que 1,0cm (nº64 Marconi), porém alguns não apresentaram lesões (n¹9 - BGH 3884, n67 - Mulato Dulce, n¹13 - IAC \#63, n²33 - Jalapeno e n³02 - BG 3883). Aos 7 DAI todos os acessos apresentavam lesões, destacando alguns com valores inferiores a $0,5 \mathrm{~cm}$, como $\mathrm{n}^{\circ} 40$ - Catarino Cascabel (0,5cm), n52 - El Saltenito (0,3cm), n56 - ICA \#131 $(0,5 \mathrm{~cm}), \mathrm{n}^{\circ} 61$ - Jalapeno (Cica)n ${ }^{\circ} 1(0,2 \mathrm{~cm}), \mathrm{n}^{\circ} 67$ - Mulato Dulce $(0,5 \mathrm{~cm}), \mathrm{n}^{\circ} 214-$ Arivivi \#261 (0,3cm), n²33 - Jalapeno (0,2cm) e n³02 - BG 3883 (0,4cm). Os demais apresentaram diâmetro de lesão maior, com até 2,8cm como no acesso n³9 Caprioglio. Aos 11 DAI raros acessos apresentavam diâmetro de lesão inferior a 1,0cm, destacando-se: $n^{\circ} 40$ - Catarino Cascabel (0,7cm), $n^{\circ} 52$ - El Saltenito (0,6cm), $n^{\circ} 61$ Jalapeno (Cica)n ${ }^{\circ}(0,6 \mathrm{~cm}), \mathrm{n}^{\circ} 72$ - C. annuum 187331 (0,9cm) e n²14 - Arivivi \#261 (0,6cm). Os demais apresentaram até 4,2cm de diâmetro de lesão (nº11 - Avelar).

Henz et al. (1993a) selecionaram 52 acessos de Capsicum spp. conforme suas reações à antracnose. Apenas três acessos apresentaram reação de resistência, 18 se 
comportaram como intermediários e 31 como suscetíveis. A avaliação foi realizada aos 4 DAI e o diâmetro das lesões variou de 0,11mm (CNPH 2686 e AVRDC 17) a 1,93mm (CNPH 2811). Dentre os materiais avaliados estava o Agronômico 10G, que apresentou diâmetro de lesão de 1,63mm sendo classificado como suscetível. No presente ensaio, o Agronômico 10G apresentou diâmetro de lesão de 0,52cm aos 3 DAI, sendo classificado ao final das avaliações como suscetível, concordando com os dados obtidos por Henz et al. (1993a).

Lobo Jr. et al. (2001) também verificou elevados diâmetros de lesões nos genótipos de $C$. annuum suscetíveis à doença, porém àqueles considerados resistentes não foram infectados. Kaur et al. (1983) avaliaram a resistência à antracnose em frutos de C. annuum, aos 10 DAI. Os frutos inoculados desenvolveram sintomas aos 2 DAI. Em duas das variedades testadas, o fungo não se desenvolveu além do ponto de infecção, caracterizando resistência. No presente ensaio, todos os materiais testados desenvolveram sintomas, porém com diâmetros de lesões variáveis, discordando dos dados apresentados por Kaur et al.(1983), não sendo possível encontrar frutos sem lesões.

A variação apresentada na velocidade de crescimento de lesões foi muito ampla. Observou-se crescimento de 0,02 cm/dia para o acesso $\mathrm{n}^{\circ} 233$ - Jalapeno, considerada a menor velocidade quando comparada com o acesso n54 - IAC 8 Mogi, que apresentou a maior velocidade de crescimento de lesão $(0,47 \mathrm{~cm} / \mathrm{dia})$. Destacaramse apenas os seguintes acessos, velocidade menor que $0,15 \mathrm{~cm} / \mathrm{dia}, \mathrm{n}^{\circ} 1-\# 124(0,14$ cm/dia), n²3 - BG 3878 (0,12 cm/dia), n40 - Catarino Cascabel (0,08 cm/dia), $n^{\circ} 42$ Catie 8063 (0,12 cm/dia), n52 - El Saltenito (0,06 cm/dia), n56 - ICA \#131 (0,12 cm/dia), n61 - Jalapeno (Cica) n¹ (0,07cm/dia), n72 - C. annuum 187331 (0,10 cm/dia), n 73 - PI 188476 (0,15 cm/dia), n²41 - Arivivi \# 261 (0,07 cm/dia), n²33 Jalapeno (0,02 cm/dia) e n³02 - BG 3883 (0,12 cm/dia) (Tabela 4).

Considerando-se intervalos de valores de velocidade de crescimento de lesão, verificou-se que a maioria dos acessos apresentou entre 0,16 e 0,25 cm/dia (36,67\% dos acessos) e entre 0,25 e $0,35 \mathrm{~cm} /$ dia (34,44\%) (Figura 2). 
Conforme Amorim (1995), caracteriza-se como período latente o tempo decorrido entre a inoculação (contato entre o patógeno e o hospedeiro) até o aparecimento de estruturas reprodutivas do patógeno. Existe variabilidade quanto à latência dentro de um mesmo patossistema. Latência maior indica maior resistência da planta à colonização. Esta é uma variável importante para estabelecer o grau de resistência ou suscetibilidade do hospedeiro. Período latente longo significa menor número de ciclos do patógeno sobre determinada variedade, num sistema policiclico. Consequentemente, deverá haver menor quantidade de doença ao final do ciclo da cultura. Este é um dos parâmetros que mais influencia a velocidade de crescimento da epidemia. Em um patossistema em particular, o período latente reflete o comportamento do patógeno em interação com o hospedeiro e o ambiente. Longos períodos latentes indicam hospedeiro resistente e/ou patógeno menos agressivo e/ou ambiente desfavorável.

A reação dos acessos à antracnose quanto ao período latente variou de 3 (n 46 - CNPH 146, n54 - IAC 8 Mogi e n³08 - Catei 7300 \#121) a 7 dias após a inoculação (DAI) (n61 - Jalapeno (Cica) $n^{\circ} 1$ e $n^{\circ} 233$ - Jalapeno). O restante dos acessos oscilou entre estes valores, compreendendo 3,33\% com período latente de 3 DAI, 31,11\% com 4 DAI, 51,11\% com 5 DAI, 12,22\% com 6 DAI e 2,22\% com 7 DAI (Figura 3). É bem evidente que a reação dos acessos com maior período latente também apresentaram menor velocidade de crescimento de lesão (n61 - Jalapeno (Cica)n ${ }^{\circ} 1$ e $n^{\circ} 233$ Jalapeno). Existe associação bem próxima de ambos parâmetros na expressão da resistência (Tabela 4).

Analisando-se os dados obtidos com incidência (\%), observou-se um aumento gradativo da primeira avaliação aos 3 DAI para a última avaliação aos 11 DAI (Tabela 4). Somente 13,33\% dos acesso apresentaram 100\% de incidência na primeira data de avaliação. Com o progresso da doença, esta percentagem aumentou para 54,44\% e 67,78\% nas avaliações realizadas aos 7 DAI e 11 DAI, respectivamente. Alguns acessos (14,44\%) apresentaram incidência entre 85\% e 99\% aos 11 DAI. Isso significa que apenas alguns frutos inoculados não apresentaram doença, o que poderia ser interpretado como escape ou erro experimental. Somente poucos acessos (6,67\%) apresentaram 
incidência inferior a 50\% aos 11 DAI. Poderia neste caso, haver associação com outros parâmetros que reduzem a expressão da resistência como menor velocidade de crescimento de lesão e período latente prolongado.

Os diâmetros de lesões apresentados por C. baccatum aos 3 DAI foram baixos, não excedendo 0,6cm ( $\mathrm{n}^{\circ} 240$ - Pimenta Coração), sendo que algumas pimentas não apresentaram lesões (Tabela 4). Aos 7 DAI todos apresentavam lesões, maiores ou menores, respectivamente, $n^{\circ} 232$ - ICA \#65 (2,2cm) e n³40 - ICA \#60 (0,4cm). Aos 11 DAI, nenhum dos acessos apresentaram valores inferiores a $0,8 \mathrm{~cm}\left(\mathrm{n}^{\circ} 222-\mathrm{BGH}\right.$ 4176). O maior diâmetro de lesão foi apresentado pelo n²32 - ICA \#65 com 3,5cm.

Santos et al. (2004) estudaram a severidade da antracnose em frutos verdes e maduros de C. baccatum. Foi verificado que os maiores diâmetro das lesões aos 8 DAI foram de 27,1 e 29,1mm, respectivamente para frutos verdes e maduros. Os materiais considerados resistentes oscilaram entre 14,4 e 18,1mm, quando maduros. No presente trabalho, o maior diâmetro de lesão foi de 3,5cm, porém, aos 11 DAI. Se considerarmos a avaliação aos 7 DAI, o maior diâmetro foi de 2,2cm, valor semelhante ao encontrado por Santos et al. (2004).

A velocidade de crescimento das lesões no grupo de pimentas de C. baccatum oscilou entre 0,08 cm/dia no acesso $\mathrm{n}^{\circ} 222$ - BGH 7176, apresentando a menor velocidade de crescimento em comparação com o acesso n²32 - ICA \#65 que apresentou maior velocidade $(0,37 \mathrm{~cm} / \mathrm{dia})$. Considerando-se os mesmos intervalos de velocidade de crescimento de lesão de $C$. annuum, a maioria dos acessos de $C$. baccatum apresentaram velocidade entre 0,16 a $0,25 \mathrm{~cm} /$ dia (46,67\% dos acessos) e entre 0,26 a 0,35 cm/dia (43,33\%). A reação da velocidade de crescimento de lesões em C. baccatum foi similar à observada em C. annuum (Figura 2).

A reação de C. baccatum à antracnose quanto ao período latente variou de 3 DAI (n²10 - Aji Limo e n²25 - BGH 5025) a 7 DAI (n²39 Pimenta Cambuci). Destacou-se o acesso n²39 Pimenta Cambuci com o maior período latente (7 dias) e também com uma das menores velocidade de crescimento de lesão $(0,17 \mathrm{~cm} / \mathrm{dia})$. Novamente houve forte relação entre estas variáveis (Tabela 4), como observado para $C$. annuum. Os outros acessos apresentaram período latente entre estes valores (Figura 3). 
A incidência nos frutos no grupo de $C$. baccatum segue o mesmo padrão de distribuição de C. annuum. Na primeira data de avaliação foram observados os menores valores e, com o progresso da doença, aumentando até os 11 DAI. Aos 3 DAI, 3,33\% dos acessos apresentou 100\% de incidência e 23,33\% com 0\% de incidência. Com o decorrer das avaliações, a incidência aumentou para 20\% e 50\% aos 7 e 11 DAI, respectivamente. Na última avaliação, 26,67\% dos acessos apresentaram incidência superior a $85 \%$, que, da mesma forma que em C. annuum, os frutos sem doença foram considerados escapes ou erro experimental. Os demais acessos (23,33\%) estiveram acima de 50\% de incidência (Tabela 4).

Quanto ao diâmetro das lesões em frutos de pimentas de C. chinense (Tabela 4), apenas o acesso n¹45 - PI 152225 não apresentou lesão aos 3 DAI, enquanto que os demais apresentaram amplitude entre $0,1 \mathrm{~cm}$ e $0,6 \mathrm{~cm}$ ( $n^{\circ} 122$ - Pimenta). Aos 7 DAI 100\% dos acessos apresentavam lesões. O maior diâmetro, nesta avaliação, foi apresentado pelo acesso $\mathrm{n}^{\circ} 143$ - Rabo de Macaco, com 1,93cm. Aos 11 DAI, apenas dois acessos apresentaram diâmetro inferior a 2,0cm. O maior diâmetro de lesão foi apresentado pelo acesso $\mathrm{n}^{\circ} 143$ - Rabo de Macaco, com 3,2cm.

Em ensaio conduzido por Lobo Jr. et al. (2001) foram testados quanto à reação à antracnose 63 acessos de Capsicum spp., destes, apenas quatro acessos de $C$. chinense não foram infectados pelo patógeno, em avaliação aos 7 DAI. Os demais apresentaram diâmetro de lesões variável. Henz et al. (1993b) avaliaram a resistência de 26 acessos de C. chinense à antracnose. Destes, apenas oito foram considerados altamente resistentes, os demais apresentaram diâmetro de lesões elevados.

Santos et al. (2004) também verificaram diâmetros de lesões elevados, aos 8 DAI, nos acessos de $C$. chinense suscetíveis à antracnose, concordando os dados apresentados neste ensaio, onde foi apresentado diâmetro de até $1,93 \mathrm{~cm}$ e 3,20cm aos 7 e 11 DAI, respectivamente. Os materiais avaliados por Santos et al. (2004) considerados resistentes, apresentaram diâmetro de lesões de 14,4 a 18,1mm. Neste ensaio, destacaram-se como resistentes os acessos que apresentaram diâmetro de 0,7 a 0,8 cm, aos 7 DAI, bem abaixo dos valores encontrados por Santos et al. (2004). 
A reação do acessos de $C$. chinense (Tabela 4) expressos na velocidade de crescimento de lesão, foi maior que nas outras espécies de Capsicum. Observou-se que $37,5 \%$ foram classificados no intervalo de velocidade de crescimento de lesão de 0,16 a $0,25 \mathrm{~cm} /$ dia, $56,25 \%$ no intervalo de 0,26 a $0,35 \mathrm{~cm} /$ dia e $6,25 \%$ acima de $0,36 \mathrm{~cm} /$ dia (Figura 2). A maior velocidade de crescimento de lesão foi observada com o n 143 Rabo de Macaco (0,36 cm/dia), enquanto que a menor foi na pimenta $\mathrm{n}^{\circ} 141$ - Pimenta $\mathrm{n}^{\circ} 2$, com 0,18 cm/dia (Figura 2).

Embora os valores de velocidade de crescimento de lesão tenham sido maiores, em contrapartida, o período latente foi relativamente longo. Cerca de $87 \%$ dos acessos apresentaram período latente de 5 dias e apenas dois (n¹19 - Murupi IH 1490 e n¹30 Pimenta Doce) com período latente menor (3 dias) (Figura 3).

Considerando-se a incidência em C. chinense, na primeira data de avaliação, aos 3 DAI, observou-se que 12,5\% dos acessos apresentaram 100\% de incidência e 6,25\% apresentaram $0 \%$ de incidência. A percentagem de acessos com incidência de 100\% foi aumentada para 43,75\% dos acessos aos 7 DAI e permaneceu estável neste patamar aos 11 DAI. Uma boa parte dos acessos (50\%) apresentou incidência maior que 85\%. Dentre estes, apenas um ou dois frutos, entre os 15 inoculados, não apresentaram lesão, sendo este fato considerado escape ou erro experimental. Os demais acessos (6,25\%) apresentaram incidência entre 50\% e 85\% (Tabela 4).

Para C. frutescens, o único acesso testado apresentou diâmetros de lesão de 0,04; 1,25 e 1,82cm, respectivamente aos 3 , 7 e 11 DAI, velocidade de crescimento de lesão de 0,22 cm/dia, período de latência de 5 dias, incidências de 20, 80\% e 90\%, respectivamente aos 3, 7 e 11 DAI (Tabela 4). Este foi considerado como suscetível à doença.

Santos et al. (2004) também verificaram a resistência de genótipos de $C$. frutescens à antracnose. No estádio de frutos verdes, os dois genótipos resistentes apresentaram 12,4 e 13,3mm. O maiores diâmetro de lesões foi de 27,1mm, em avaliação aos 8 DAI.

O segundo experimento de inoculação (Tabela 4) foi realizado com o propósito de confirmar os dados apresentados no primeiro experimento. É possível verificar que os 
acessos apresentaram valores semelhantes, para as variáveis analisadas, em ambos experimentos, confirmando a classificação dos acessos realizada no primeiro experimento. Os coeficiente de correlação entre os dois experimentos foram realizados com base na avaliação do diâmetro das lesões aos 11 DAI e na velocidade de crescimento de lesões. Foi observada correlação positiva de 74\% entre as avaliações aos 11 DAI e de 70\% entre as velocidades de crescimento de lesões (Tabela 5).

Tabela 5 Análise de correlação entre o primeiro e o segundo experimento de inoculação em frutos, para as variáveis diâmetro de lesões aos 11 DAI e velocidade de crescimento de lesões

\begin{tabular}{lcc}
\hline Primeiro experimento & \multicolumn{2}{c}{ Segundo experimento } \\
& Diâmetro de lesões aos 11 DAI & Velocidade de cresc. de lesões \\
\hline Diâmetro de lesões aos 11 DAI & $0,74^{1}$ & 0,61 \\
& $0,0001 *$ & $0,0001 *$ \\
Velocidade de cresc. de lesões & 0,76 & 0,70 \\
& $0,0001 *$ & $0,0001 *$ \\
\hline 1- análise de correlação; * - Correlação significativa pelo teste F a $5 \%$ de probabilidade.
\end{tabular}

- análise de correlação; * - Correlação significativa pelo teste F a 5\% de probabilidade.

As avaliações referentes aos diâmetros de lesão das progênies originadas dos retrocruzamentos entre (C. annuum x C. chinense) x C. annuum, geração F3RC1 e [(C. annuum x C. chinense) x C. annuum] x C. annuum, geração F2RC2, estão apresentadas na Tabela 6. Aos 3 DAI a maioria das progênies apresentou diâmetro inferior a 1,0cm, apenas as progênies $18 \mathrm{~F}(1,5 \mathrm{~cm}), 34 \mathrm{G}(1,1 \mathrm{~cm})$ e $37 \mathrm{H}(1,8 \mathrm{~cm})$ estavam acima deste valor, porém 41,2\% não apresentaram lesão. Aos 7 DAI apenas 12,3\% das progênies não apresentavam lesões. Os demais oscilaram entre 0,3cm (progênies 9H, 39C, e 39D) e 4,2cm (progênie 27E). Na última avaliação, realizada aos 11 DAI o maior diâmetro de lesão apresentado foi pela progênie $27 \mathrm{E}$, com 5,8cm e o menor diâmetro foi de $0,7 \mathrm{~cm}$, apresentado por 4C e 7A. Nesta avaliação, 10\% das progênies não apresentaram lesões, sendo considerados resistentes.

A velocidade de crescimento das lesões das progênies foi muito variável, indicando possível segregação genética para este parâmetro epidemiológico. Os dados oscilaram entre 0,00 e $0,72 \mathrm{~cm} /$ dia (27E). A menor velocidade de crescimento de lesão, excluindo-se àqueles com valor 0,00 , foi a progênie $7 \mathrm{~A}$ com $0,08 \mathrm{~cm} /$ dia, o qual, chegou 
ao final das avaliações com 100\% de incidência, porém, sem esporulação. As progênies que não apresentaram lesão foram: 3G, 4A, 4B, 4F, 4H, 5H, 6B, 6F, 8B, 8E, 8F, 9B, 9D, 9E, 9J, 10A, 13D, 13F, 14A, 14C, 16D, 16I, 17B, 19B, 33F e 40G, compreendendo 10\% das progênies. A predominância de progênies F3RC1 das numerações de 1 a 19, foram maiores do que no grupo com dois retrocruzamentos pata C. annuum (F2RC2). Estes resultados indicam que, ao retrocruzar para C. annuum, com parental suscetível, ainda existe variabilidade residual suficiente para seleção visando resistência à antracnose. No intervalo de 0 a $0,15 \mathrm{~cm} /$ dia, encontram-se $5 \%$ das progênies, entre 0,16 e 0,25 cm/dia têm-se 5,38\% das progênies, entre 0,26 e 0,35 têm-se 23,46\% e acima de 0,36 cm/dia estão 50\% das progênies (Tabela 6).

A maioria das progênies apresentou período latente curto, com 13,46\% e 61,92\% das progênies com período latente de 3 e 5 DAI, respectivamente. Das demais, 10\% apresentaram período latente de 7 DAI; 1,92\% aos 9 dias; 1,54\% aos 11 DAI e 11,15\% das progênies não apresentaram lesões ou não esporularam no período de avaliação. As progênies que apresentaram período latente longo (11 dias) foram: 4C, 4G, 16F e 18C. As que não esporularam foram: progênies 3G, 4A, 4B, 4F, 4H, 5H, 6B, 6F, 6D, 7A, 8B, 8E, 8F, 9B, 9D, 9E, 9J, 10A, 13D, 13, 13I, 14A, 14C, 16D, 16I, 17B, 19B, 33F e 40G (Tabela 6).

A incidência apresentada pelas progênies de pimentas e pimentões de Capsicum está apresentada na Tabela 6, podendo ser observado que aos 3 DAI, 31,54\% das progênies apresentavam 100\% de incidência, valor este que alcançou 68,84\% aos 7 DAI e 88,46\% aos 11 DAI. Ainda na última avaliação, 10\% dos acessos não apresentaram lesões, e os demais 1,54\% oscilaram entre $47,1 \%$ e $87,5 \%$ de incidência. O número de frutos utilizados foi em torno de quatro a cinco frutos, pela avaliação ter sido feita por planta individual.

Qing et al. (2002) avaliaram as progênies F2 e RC de seus cruzamentos e retrocruzamentos entre a variedade resistente '83-168'e a cultivar suscetível 'KKU Cluster'. A população apresentou segregação na proporção de 3:1 (resistente : suscetível) e a população RC em 1:1. Isso indica que a resistência à antracnose é 
condicionada por gene dominante. As incidências apresentadas pelas progênies variaram de 9 a $48 \%$.

As progênies do primeiro retrocruzameneo (F3RC1) comportaram-se como mais resistentes à antracnose em relação às originadas do segundo retrocruzamento (F2RC2). Este comportamento era esperado, pois as progênies F3RC1 possuem em sua genealogia, um primeiro cruzamento entre $C$. annuum e $C$. chinense (resistente), e a geração F1 foi retrocruzada com outro material de C. annuum, com uma expressiva variabilidade residual de $C$. chinense em sua composição genética. As progênies F2RC2, possuem pelo menos $87,5 \%$ de seus genes de C. annuum, reduzindo assim a contribuição de $C$. chinense em sua composição genética.

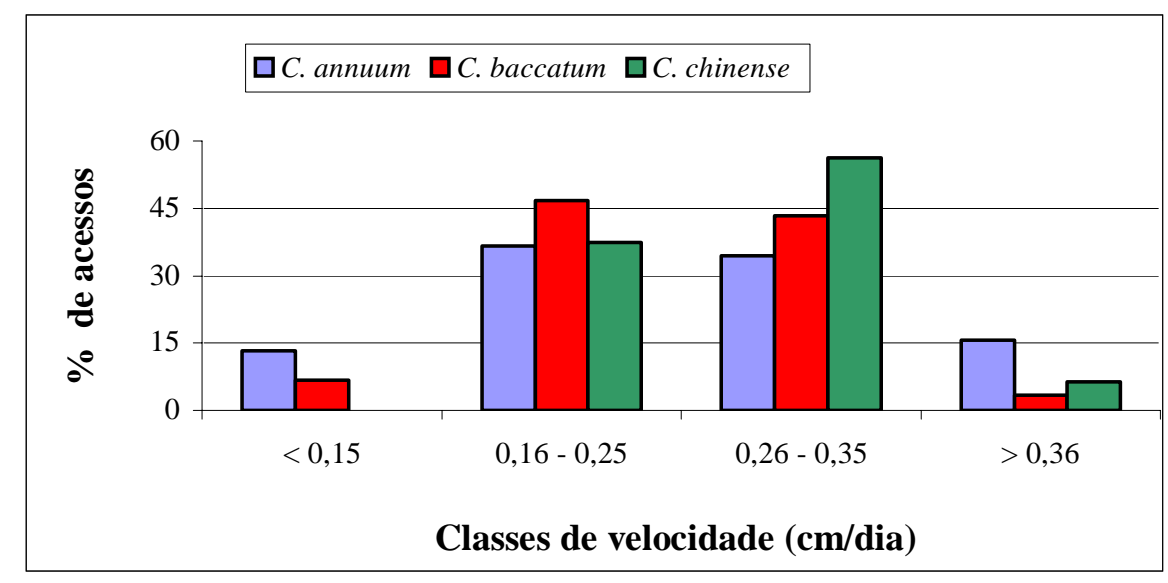

Figura 2 - Percentagem de acessos agrupados nas diferentes classes de velocidade de crescimento de lesões (cm/dia) 


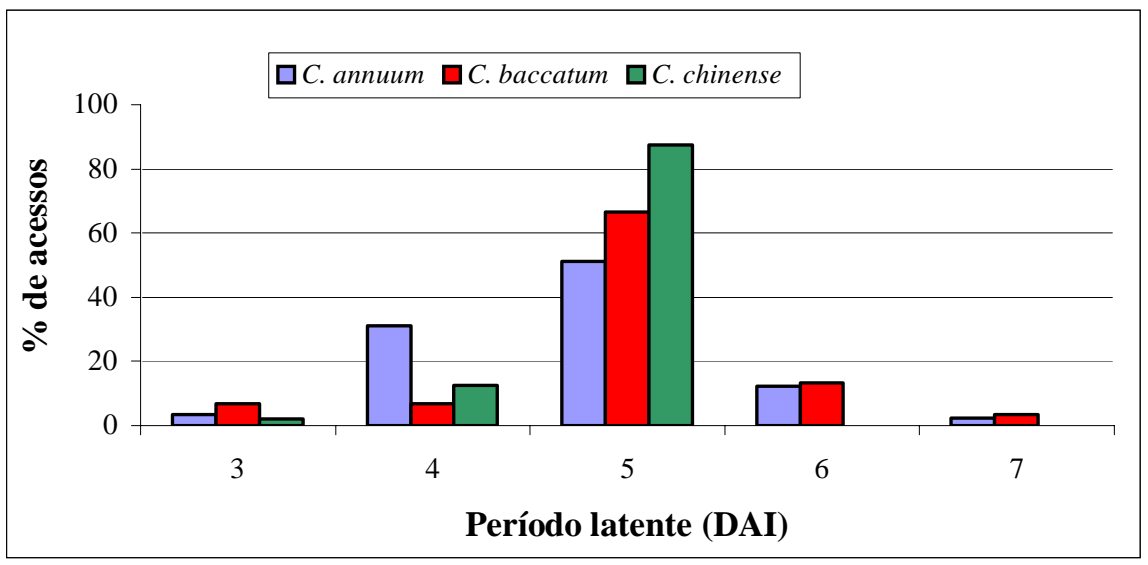

Figura 3 - Percentagem de acessos em relação ao período latente

\subsection{Análise de correlação}

Existem relatos da transmissibilidade da antracnose através das sementes, onde estas constituem o inóculo inicial da doença no campo. Na fase vegetativa, a antracnose causa sintomas de necrose e manchas (Black et al., 1991; Kurozawa \& Pavan, 1997).

Correlacionar a reação da fase vegetativa juvenil com a reação de frutos pode elucidar eventuais mecanismos de resistência à antracnose das solanáceas. Desta forma, a resistência na fase vegetativa poderia reduzir ou minimizar os danos causados pelo fungo na fase de frutificação.

As análises de correlação foram realizadas entre as avaliações de diâmetro de lesões nos frutos aos 3, 7 e 11 DAI e velocidade de crescimento de lesão com as avaliações de severidade de doença (escala de notas) nas plântulas aos 3, 10 e 19 DAI. Os resultados estão apresentados nas Tabelas 7, 8 e 9, para Capsicum annuum, C. baccatum e C. chinense, respectivamente. É possível verificar que as Tabelas 8 e 9 apresentam duas correlações. A primeira delas é referente às avaliações realizadas no primeiro experimento e a segunda equivale aos acessos utilizados no segundo experimento. 
Para C. annuum (Tabela 7) é possível verificar, no primeiro experimento, correlação direta significativa entre todas as avaliações, exceto entre a avaliação nas plântulas aos 3 DAI e a velocidade de crescimento de lesão nos frutos. A maior correlação existente foi apresentada entre a avaliação de severidade de doença nas plântulas aos 19 DAI e a avaliação de diâmetro de lesão nos frutos aos 3 DAI, com 41\% de correlação. No segundo experimento, não houve correlação entre plântulas e frutos. Este comportamento, provavelmente, deve-se ao fato da antracnose não ser uma doença característica de fase vegetativa juvenil, e sim, ser uma doença que afeta tipicamente os frutos, sendo dessa foram, difícil repetir com precisão os resultados de inoculações na fase de plântulas.

Não houve correlação entre as avaliações nas plântulas e nos frutos para os acessos de C. baccatum (Tabela 8), em nenhum dos experimentos. Em C. chinense (Tabela 9), também não houve correlação significativa entre as avaliações nas plântulas e nos frutos, exceto entre a severidade de doença 19 DAI em plântulas e diâmetro de lesão aos 11 DAI nos frutos, porém a correlação foi inversa (71\%), onde com o aumento dos valores em uma das variáveis, tem-se a diminuição dos valores na outra variável.

Rawal et al. (1983) pulverizou com inóculo, plantas no estádio de frutificação, sendo avaliado posteriormente a ocorrência de C. capsici em folhas e em frutos. Concluiu que não há correlação entre a ocorrência da doença em folhas e em frutos na cultura, o que confirmam os resultados obtidos no presente trabalho.

De modo geral, não houve correlação entre a avaliação nas plântulas e nos frutos, exceto para a espécie C. annuum, que no primeiro experimento mostrou correlação significativa, embora em percentagens inferiores a 50\%. Entretanto, no segundo experimento, essa correlação não foi observada, provavelmente devido à alteração observada na reação das plântulas nesse segundo experimento. Essa inconsistência na reação de plântulas à antracnose inviabiliza testes de seleção neste estádio.

Por outro lado, mesmo sem correlação entre a reação em folhas e frutos, plantas resistentes à antracnose na fase vegetativa são de interesse agronômico. A resistência em folhas reduziria a fonte de inóculo primário para os fruto e, 
consequentemente, diminuiria as possibilidades de ocorrência de uma epidemia ou mesmo, atrasaria a ocorrência da epidemia no campo de produção. De certa forma, esta ausência de correlação entre a reação de plântulas e frutos também pode explicar, em parte, a ocorrência de severas epidemias de antracnose nos frutos, praticamente sem constatação de sintomas nas folhas.

Embora não constatada correlação estatística à antracnose entre os estádios de avaliação, fazendo-se uma simples comparação de dados (Tabela 10), é possível verificar que há uma relação moderada entre os estádios, para os genótipos considerados suscetíveis. Quando na fase de plântula os acessos foram suscetíveis, na fase de frutos, eles apresentaram valores elevados de diâmetro de lesões. Em contrapartida, quando os acessos foram resistentes na fase de plântula, eles apresentaram comportamento muito variado na reação dos frutos, sendo classificados como resistentes ou como suscetíveis. Deste modo, num programa de melhoramento, seria altamente desejável realizar uma primeira inoculação nas plântulas, para eliminar as suscetíveis e selecionar as sobreviventes para posterior processo seletivo na fase de frutos.

\subsection{Classificação da reação de resistência - Teste de Cluster}

A reação dos acessos de pimentas e pimentão quanto à resistência à antracnose foi realizada com base em análise estatística pelo Teste Cluster para agrupamento dos acessos em grupos de reação. Esta classificação foi realizada com base nas avaliações de diâmetro de lesão dos frutos aos 11 dias após a inoculação (DAI) em conjunto com a velocidade de crescimento de lesões (cm/dia), visto que as reações nas plântulas, além de não apresentam confiávelmente repetidas, não se apresentaram adequadas para avaliar o comportamento dos frutos à doença.

A Tabela 4 apresenta a classificação dos acessos de C. annuum. Para esta espécie, foi possível discriminar cinco grupos de reação, onde apenas o acesso n²33 Jalapeno com 0,2cm, apresentou reação de resistência; 14 acessos (15,6\%) apresentaram reação de moderadamente resistente; 44 (48,9\%) comportaram-se como suscetíveis; 18 (20\%) como moderadamente suscetíveis e 13 (14,4\%) como altamente suscetíveis. 
Levando-se em consideração os acessos de C. baccatum (Tabela 4), foi possível discriminá-los em apenas três grupos de reação, onde um acesso (nº 222 - BGH 4176) comportou-se como resistente, com diâmetro de lesão de 0,8cm aos 11 DAI, 18 acessos (60\%) comportaram-se como intermediários e 11 (36,84\%) como suscetíveis.

Para a espécie C. chinense (Tabela 4), a maioria dos acessos apresentou comportamento suscetível em relação à ocorrência de antracnose. Apenas dois acessos se comportaram como resistentes ( $n^{\circ} 105$ - Bode e $n^{\circ} 141$ - Pimenta $n^{\circ} 2$, com diâmetro de lesão de 1,6 e 1,52cm, respectivamente, aos $11 \mathrm{DAI})$, quatro acessos (25\%) como intermediários e 10 (62,5\%) como suscetíveis.

Em avaliação de acessos de Capsicum spp. quanto à antracnose, Santos et al. (2004) constataram que as pimentas da espécie C. chinense (CNPH 3777, 3761, 3503 e 3784a) consideradas resistentes, apresentaram diâmetro de lesão variável entre 14,4 e 18,1mm, quando maduras, aos 8 DAI. Os autores também estudaram o comportamento dos acessos quando inoculados em frutos verdes e maduros, verificando que no estádio de frutos verdes, $15 \%$ dos acessos foram resistentes, 30\% intermediários e 55\% suscetível; e no estádio de frutos maduros, 30\% foram resistentes, 25\% intermediários e 45\% suscetível, aos 8 DAI. Estes valores estão um pouco acima dos valores encontrados neste ensaio.

Em seus ensaios, Henz et al. (1993b) avaliaram 39 acessos de C. chinense, encontrando oito genótipos altamente resistentes no estádio maduro com alteração de cor e três genótipos no estádio maduro sem alteração de cor.

O único acesso de $C$. frutescens testado apresentou suscetibilidade à doença.

Todas as espécies avaliadas apresentaram baixo número de materiais resistentes, observando um acesso de $C$. annuum, um de $C$. baccatum e dois de $C$. chinense. A maioria das pimentas e pimentões comportaram-se como intermediários e suscetíveis, confirmando os resultados de Kaur et al. (1983); Rawal et al. (1983); Choi et al. (1990); Suhardi (1991); Henz et al. (1993a); Henz et al. (1993b); Henz et al. (1994); Jeyalakshmi \& Seetharaman (1998); Roy et al. (1998); Lobo Jr et al. (2001); Santos et al. (2004), que também encontraram, em seus trabalhos, reação intermediária e suscetível, e ausência de fontes de resistência. 
Somente Gniffke (2003) identificou fontes de resistência à antracnose em seus acessos de Capsicum na Ásia. O autor inoculou frutos verdes com isolados agressivos de C. capsici, C. acutatum e C. gloeosporioides. Adotou como critério de resistência os frutos que apresentavam diâmetro de lesão menor que 0,4 mm aos 5 DAI. Com base neste critério, a maioria dos acessos foi resistente.

A fonte de resistência usada por Gniffke (2003), PBC 932 de C. chinense, serviu como fonte de resistência para introdução de genes de resistência em C. annuum no programa de melhoramento de Capsicum da ESALQ/USP, conduzido pelo Prof. Dr. Cyro Paulino da Costa.

Das progênies que não apresentaram lesões na avaliação nos frutos, foi avançada uma geração e avaliada a resistência à antracnose nas plântulas (Tabela 3). Estas populações foram designadas de F4RC1 (avanço da geração F3RC1) e F3RC2 (avanço da F2RC2). Foram utilizados o acesso n¹45 - PI 152225 como testemunha suscetível e o genótipo PBC 932 como testemunha resistente. O acesso $\mathrm{n}^{\circ} 145$ - PI 152225 apresentou o maior nível de doença em todas as avaliações, com 1,7; 3,9 e 4,3 aos 3, 10 e 19 DAI, respectivamente. O padrão de resistência PBC 932 não apresentou lesões em nenhuma das avaliações. As demais progênies apresentaram lesões, porém em baixas severidades (nota menor que 2,5), apenas a progênie 4F apresentou valores elevados, atingindo severidade de doença de 3,5 na última avaliação (19 DAI), com 100\% de incidência.

A incidência da doença nestes materiais foi muito variável, oscilando de $0 \%$ (progênie 3J, 4B e 14C) a 61\% (progênie 8E). Estes resultados para o processo seletivo são promissores, pois permitirá a obtenção de pimentas e pimentões resistentes à antracnose. Ainda é esperado ocorrer segregação para reação à antracnose na fase de frutificação. Porém os resultados aqui obtidos indicam que essas linhagens serão avaliadas quanto à reação nos frutos, uma vez que não foi constatada correlação significativa entre plântulas e frutos.

Deste modo, o critério seletivo para resistência à antracnose irá envolver a reação na fase vegetativa juvenil e preferivelmente a reação na fase de frutificação. 


\section{CONCLUSÕES}

1 Genótipos com alto nível de resistência à antracnose são escassos na coleção de Capsicum spp. avaliada.

2 Não existe correlação entre os comportamentos de plântulas e frutos de Capsicum spp. à antracnose.

3 A seleção de acessos de Capsicum spp. resistentes à antracnose deve basearse na reação apresentada pelos frutos.

4 É possível incorporar resistência à antracnose em materiais por meio de cruzamentos interespecíficos entre $C$. annuum e $C$. chinense. 


\section{REFERÊNCIAS BIBLIOGRÁFICAS}

AHMED, N.; DEY, S.K.; HUNDAL, J.S. Inheritance of resistance to anthracnose in chilli. Indian phytopathology, v.44, n.3, p.402-403, 1991.

ALEXANDER, S.A.; MARVEL, J,K. Colletotrichum gloeoporioides causes severe anthracnose on pepper in Virginia. Phytophatology, v.92, n.6, p.142, Supl., 2002.

AMORIM, L. Colonização e reprodução. In: BERGAMIN FILHO, A.; KIMATI, H.; AMORIM, L. Manual de Fitopatologia: Princípios e conceitos. 3.ed. São Paulo: Editora Agronômica Ceres, v.2, cap.16, 1997. p.309-308.

BLACK, L.L.; GREEN, S.K.; HARTMAN, G.L.; POULOS, J.M. Pepper Diseases: A Field Guide. Asian vegetable research and development center. Local: AVRDC, 1991, 98p. (AVRDC Publication n 91-347).

BLAT, S.L. Herança da reação de Capsicum spp. ao oídio (Leiveillula taurica (Lev.) ARN). Piracicaba, 2004. 153p. Tese (Doutorado) - Escola Superior de Agricultura “Luiz de Queiroz”, Universidade de São Paulo.

CAPSICUM. www.cnph.embrapa.br/capsicum, 2003. (12 set. 2003).

CARVALHO, S.I.C.; BIANCHETTI, L.B.; HENZ, G.P. Germoplasm collection of Capsicum spp. maintained by Embrapa Hortaliças (CNPH). Capsicum and Eggplant Newsletter, v. 22, p. 17-20, 2003. 
CASALI, V.W.D.; COUTO, F.A.A. Origem e botânica de Capsicum. Informe Agropecuário, v.10, n.113, p. 8-10. Maio, 1984.

CHEEMA, D.S.; SINGH, D.P.; RAWAL, R.D.; DESHPANDE, A.A. Inheritance of resistance to anthracnose disease in chillies. Capsicum and Eggplant Newsletter, v. 2, p. 44, 1984a.

CHEEMA, D.S.; SINGH, D.P.; RAWAL, R.D.; DESHPANDE, A.A. Study of phenolic constituents of resistant and suceptible lines of chillies (Capsicum annuum) in relation to anthracnose disease. Capsicum and Eggplant Newsletter, v. 3, p. 43, 1984b.

CHOI, J.K.; PARK, D.Y.; WOO, Y.H; SUNG, J. M. Studies on the resistance of red pepper varieties to Phytophthora blight and anthracnose. Research Reportes of the Rural Development Administration Horticulture, v. 32, n. 2, p. 1-9, 1990.

DOOLITTLE, S.P. Diseases of peppers. Plant Diseases: The Yearbook of Agriculture. United States Department of Agriculture. Washington, D. C., 1953, p. 466-469.

FELIX, A.A.A.; MENDES, M.A.S.; SANTOS, M.F.; PAULO, J.A.O. Fungos de expressão quarentenária para o Brasil. Fitopatologia Brasileira, n. 28, p. 207, Supl., 2003.

FERNANDES, M.C.A.; SANTOS, A.S.; RIBEIRO, R.L.D. Adaptação patogênica de isolados de Colletotrichum gloeosporioides obtidos de frutos de jiloeiro, pimentão e berinjela. Summa Phytopathologica, v. 28, n. 4, p. 325-330, 2002. 
FILGUEIRA, F.A.R. Manual de Olericultura: cultura e comercialização de hortaliças. 2.ed. São Paulo: Editora Agronômica Ceres, 1982, v.2, cap.9, p.301-318: Olericultura especial.

FNP CONSULTORIA \& COMÉRCIO. Agrianual 2004: anuário da agricultura brasileira. São Paulo, 2004. p.412-414: Pimentão.

GNIFFKE, P. Host resistance to pepper anthracnose. Progress Report. Shanhua, Taiwan: AVRDC - the World Vegetable Center. 2003. www.avrdc.org/pdf/03anthracnose.pdf. (01 jun. 2003)

HALFELD-VIEIRA, B.A.; NECHET, K.L.; PEREIRA, P.R.V.S.; MOURÃO JUNIOR, M. Incidência da antracnose em frutos de cinco híbridos de pimentão em condições de cultivo protegido. Fitopatologia Brasileira, v.29, Supl., p.33, 2004.

HEGDE, G.M.; ANAHOSUR, K.H. Biochemical basis of resistance to fruit rot (Colletotrichum capsici) in chilli genotypes. Karnataka Journal of Agricultural Sciences, v.14, n.3, p.686-690, 2001.

HENZ, G.P.; BOITEUX L.S.; LIMA, M.F. Reaction of Capsicum spp. fruits to Colletotrichum gloeosporioides. Capsicum and Eggplant Newsletter, v.12, p.79-80, 1993a.

HENZ, G.P.; BOITEUX, L.S.; LIMA, M.F.; PESSOA, H.B.S.V. Resistência de frutos de Capsicum chinense a Colletotrichum gloeosporioides. Horticultura Brasileira, v.11, n.1, p.75, 1993b.

HENZ, G.P.; BOITEUX, L.S.; LIMA, M.F. Fontes de resistência em Capsicum spp. a Colletotrichum gloeosporioides. Horticultura Brasileira, v.12, n.1, p.82, 1994. 
HONG, J.K.; HWANG, B.K. Influence of inoculum density, wetness duration, plant age, inoculation method, and cultivar resistance on infection of pepper plants by Colletotrichum coccodes. Plant Disease, v.82, n.10, p.1079-1083, 1998.

HONG, J.K.; LEE, Y.K.; JEUN, Y.C.; HWANG, B.K. Histological and ultrastructural study of susceptible and age-related resistance responses of pepper leaves to Colletotrichum coccodes infection. Plant Pathology Journal, v.17, n.3, p.128-140, 2001.

IVEY, M.L.L.; NAVA-DIAZ, C.; MILLER, S.A. Identification and management of Colletotrichum acutatum on immature bell pepper. Plant Disease, v.88, n.11, p.1198-1204, 2004.

JEYALAKSHMI, C.; SEETHARAMAN, K. Evaluation of chilli genotypes against fruit rot disease incited by Colletotrichum capsici (syd) Butler and Bisby. South Indian Horticulture, v.46, n.1/2, p.104-105, 1998.

JEYALAKSHMI, C.; SEETHARAMAN, K.; EBENEZER, E. G. Qualitative losses of chilli fruits due infection by Colletotrichum capsici (Syd) Butler and Bisky. Capsicum and Eggplant Newsletter, v.18, p.80-82, 1999.

KAUR, S.; THAKUR, M.R.; SINGH, J; SOOCH, B.S. Fruit rot of hot pepper (Capsicum annuum) caused by Colletotrichum acutatum. Capsicum and Eggplant Newsletter, v.2, p.123-125, 1983.

KIM, K.D.; OH, B.J.; YANG, J. Differential interactions of a Colletotrichum gloeosporioides isolated with green and red pepper fruits. Phytoparasitica, v.27, n.2, p.97-106, 1999. 
KUROZAWA, C.; PAVAN, M.A. Doenças das solanáceas (beringela, jiló, pimentão e pimenta), In: KIMATI, H.; AMORIM, L.; BERGAMIN FILHO, A.; CAMARGO, L.E.A.; REZENDE, J.A.M. Manual de Fitopatologia: Doenças das plantas cultivadas. 3.ed. São Paulo: Editora Agronômica Ceres, 1997, v.2, p.665-675.

LOBO JUNIOR, M.; SILVA-LOBO, V.L.; LOPES, C.A. Reação de genótipos de Capsicum spp. (pimentas e pimentão) à antracnose (Colletotrichum gloeosporioides). Fitopatologia Brasileira, v.26, p.373, Supl., 2001.

MANANDHAR, J.B.; HARTMAN, G.L.; WANG, T.C. Anthracnose development on pepper fruits inoculated with Colletotrichum gloeosporioides. Plant Disease, v.79, n.4, p.380-383, 1995.

McGOVERN, R.J. First report of fruit rot of Capsicum chinense caused by two Colletotrichum species. Plant Disease, v.79, p.212, 1995.

OH, B.J.; KIM, K.D.; KIM, Y.S. Effect of cuticular wax layers of green and red pepper fruits on infection by Colletotrichum gloeosporioides. Journal of Phytopathology, v.147, n.9, p.547-552, 1999.

PARK, H.K.; KIM, B.S.; LEE, W.S. Inheritance of resistance to anthracnose (Colletotrichum spp.) in pepper (Capsicum annuum L.). II. Genetic analysis of resistance to Colletotrichum dematium. Journal of the Kerean Society for Horticutural Science, v.31, n.3, p.207-212, 1990.

PARK, K.S.; KIM, C.H.; LEE, E.J. Five fungal species associated with anthracnose of red-pepper in Korea. Phytopathology, v.81, n.10, p.1135, 1991. 
PEREIRA, R. M. F. V. Caracterização morfológica, fisiológica, serológica e eletroforética de Colletotrichum gloeosporioides "SENSU" Arx, isolados de pimentão (Capsicum annuum L.) e jiló (Solanum gilo Raddi), e seu controle químico. Piracicaba, 1995. 151p. Tese (Doutorado) - Escola Superior de Agricultura “Luiz de Queiroz”, Universidade de São Paulo.

PIMENTAS QUENTES. www.geocities.com/NapaValley/1819. (12 set. 2003).

QING，L.; KANCHANA-UDOMKARN，C.; JAUNET, T.; MONGKOLPORN, O. Inheritance of resistance to pepper anthracnose caused by Colletotrichum capsici. Capsicum and Eggplant Newsletter, v.21, p.85-88, 2002.

RAWAL, R.D.; DESHPANDE, A.A.; SINGH, D.P.; PATHAK, C.S. Resistant sources for anthracnose fruit rot (Colletotrichum capsici) in chilli peppers (Capsicum spp.). Capsicum and Eggplant Newsletter, v.2, p.126-127, 1983.

RIBEIRO, C.S. da C.; CRUZ, D.M.R. Comércio de sementes de pimentão está em expansão. Apenas o mercado nacional movimenta US\$ 1,5 milhão. Revista Cultivar Hortaliças e Frutas, n.21, Set. 2003.

ROCHA, M.C.; SUDO-MARTELLETO, M.; CARMO, M.G.F.; FERNANDES, M.C.A.; SILVA, D.A.G.; MOYSÉS, R.M.A.; MANERA, T.C.; GEDDA, A.E.D.C.; COSTA, E.S.P. Incidência de antracnose em frutos de pimentão pulverizados com cobre e biofertilizande Agrobio. Summa Phytopathologica, v.30, n.1, p.117, 2004.

ROY, A.; BORDOLOI, D.K.; PAUL, S.R. Reaction of chilli (Capsicum annuum L.) genotypes to fruit rot under field conditions. PKV Research Journal, v.22, n.1, p.155, 1998. 
SALGADO, C.L.; TOKESHI, H. Doenças das Solanáceas. In: GALLI, F. Manual de Fitopatologia: Doenças das plantas cultivadas. São Paulo: Editora Agronômica Ceres, 1980, v.2, cap.34. p.497-510.

SANTOS, M.R. dos; HENZ, G.P.; LIMA, M.L.P.; CAFÉ FILHO, A.C. Reação de frutos verdes e maduros de Capsicum spp. a antracnose. Fitopatologia Brasileira, v.29, p.58, Supl., 2004.

SUHARDI. Resistance of pepper (Capsicum spp.) against Colletotrichum gloeosporioides at the seedling stage. Buletin Penelitian Hortikultura (Indonésia), v.20, n.1, p.83-85, 1991.

TOZZE JUNIOR, H.J.; BUENO, C.R.N.C.; MASSOLA JUNIOR, N.S. Caracterização morfológica e molecular de isolados de Colletotrichum sp. de hortaliças solanáceas. Summa Phytopathologica, v.30, n.1, p.73, 2004.

YOON, J.B.; PARK, H.G. Screening method for resistance to pepper fruit anthracnose: pathogen sporulation, inoculation methods related to inoculum concentrations and post-inoculation environment. Journal of the Korean Society for Horticultural Science, v.42, n.4, p.389-393, 2001. 
APÊNDICES 
Tabela 1 Germoplasma de Capsicum spp., acessos, local de origem, cor do fruto quando verde e quando maduro, formato do fruto e espécie de Capsicum, caracterizado quanto à reação à antracnose em plântulas e em frutos

\begin{tabular}{|c|c|c|c|c|c|c|}
\hline \multirow[t]{2}{*}{$\mathbf{N}^{\circ}$} & \multirow[t]{2}{*}{ Acessos } & \multirow[t]{2}{*}{ Origem } & \multicolumn{2}{|c|}{ Cor do fruto } & \multirow[t]{2}{*}{ Formato } & \multirow[t]{2}{*}{ Espécie } \\
\hline & & & Verde & Maduro & & \\
\hline 01 & \# 124 & Filipinas & Verde & Vermelha & Cônico & C. annuum \\
\hline 02 & \# 132 & Filipinas & Verde & Vermelha & Cônico & C. annuum \\
\hline 03 & \# 138 & Filipinas & Verde & Vermelha & Retangular & C. annuum \\
\hline 04 & \# 36 & Filipinas & Verde & Vermelha & Comprida & C. annuum \\
\hline 05 & \# 5 & Brasil & Verde & Vermelha & Cônico & C. annuum \\
\hline 06 & \# 125 & Filipinas & Verde & Vermelha & Cônico & C. annuum \\
\hline 07 & Agronômico 10G & Brasil & Verde & Vermelha & Cônico & C. апnиuт \\
\hline 08 & Ancho & México & Verde & Vermelha & Cônico & C. апnиит \\
\hline 09 & Ano todo & Brasil & Verde & Vermelha & Cônico & C. апnиит \\
\hline 10 & Argentina \# 3 & Brasil & Verde & Vermelha & Cônico & C. апnиит \\
\hline 11 & Avelar & Brasil & Verde & Vermelha & Cônico & C. annuum \\
\hline 12 & BGH 3058 & Brasil & Verde & Chocolate & Cônico & C. annuum \\
\hline 13 & BGH 3464 & Brasil & Verde & Vermelha & Cônico & C. annuum \\
\hline 14 & BGH 3058 & Brasil & Verde & Vermelha & Cônico & C. annuит \\
\hline 15 & BGH 3743 & Brasil & Verde & Vermelha & Retangular & C. annuum \\
\hline 16 & BGH 3744 & Brasil & Verde & Vermelha & Cônico & C. annuum \\
\hline 17 & BGH 3756 & Brasil & Verde & Vermelha & Cônico & C. annuum \\
\hline 18 & BGH 3757 & Brasil & Verde & Vermelha & Cônico & C. annuum \\
\hline 19 & BGH 3884 & Brasil & Verde & Vermelha & Cônico & C. annuum \\
\hline 20 & BGH 3886 & Brasil & Verde & Vermelha & Cônico & C. annuum \\
\hline 21 & BGH 3890 & Brasil & Verde & Vermelha & Cônico & C. annuum \\
\hline 22 & BGH 3896 & Brasil & Verde & Vermelha & Cônico & C. annuum \\
\hline 23 & BG 3878 & Brasil & Verde & Vermelha & Comprida & C. annuum \\
\hline 24 & BGH 3978 & Brasil & Verde & Vermelha & Comprida & C. annuum \\
\hline 25 & BGH 3464 & Brasil & Verde & Vermelha & Cônico & C. annuum \\
\hline 26 & BGH 3714 & Brasil & Verde & Vermelha & Cônico & C. annuum \\
\hline 27 & BGH 3756 & Brasil & Verde & Vermelha & Cônico & C. апnиuт \\
\hline 28 & BGH 3756 & Brasil & Verde & Vermelha & Cônico & C. annuum \\
\hline 29 & BGH 3757 & Brasil & Verde & Vermelha & Comprida & C. annuum \\
\hline 30 & BGH 3758 & Brasil & Verde & Vermelha & Cônico & C. annuum \\
\hline 31 & BGH 3881 & Brasil & Verde & Vermelha & Comprida & C. annuum \\
\hline 32 & BG 3883 & Brasil & Verde & Vermelha & Cônico & C. апnиuт \\
\hline 33 & BGH 3888 & Brasil & Amarela & Vermelha & Cônico & C. annuum \\
\hline
\end{tabular}


Tabela 1 Germoplasma de Capsicum spp., acessos, local de origem, cor do fruto quando verde e quando maduro, formato do fruto e espécie de Capsicum, caracterizado quanto à reação à antracnose em plântulas e em frutos

\begin{tabular}{|c|c|c|c|c|c|c|}
\hline \multirow[t]{2}{*}{$\mathbf{N}^{\circ}$} & \multirow[t]{2}{*}{ Acessos } & \multirow[t]{2}{*}{ Origem } & \multicolumn{2}{|c|}{ Cor do fruto } & \multirow[t]{2}{*}{ Formato } & \multirow[t]{2}{*}{ Espécie } \\
\hline & & & Verde & Maduro & & \\
\hline 34 & BGH 3889 & Brasil & Roxa & Vermelha & Cônico & C. annuит \\
\hline 36 & BGH 4016 & Brasil & Verde & Vermelha & Cônico & C. annuum \\
\hline 38 & Calahora & México & Verde & Vermelha & Retangular & C. annuum \\
\hline 39 & Caprioglio & Itália & Verde & Vermelha & Redondo & C. annuum \\
\hline 40 & Catarino Cascabel & México & Verde & Vermelha & Comprida & C. annuum \\
\hline 42 & Catie 8063 & Costa Rica & Verde & Amarela & Cônico & C. annuum \\
\hline 43 & Chili & Índia & Verde & Vermelha & Compr. fina & C. annuum \\
\hline 44 & CNPH 144 & Brasil & Verde & Vermelha & Comprida & C. апnиит \\
\hline 45 & CNPH 145 & Brasil & Verde & Vermelha & Cônico & C. апnиит \\
\hline 46 & CNPH 146 & Brasil & Verde & Marrom & Cônico grande & C. апnиит \\
\hline 47 & CNPH 162 & Brasil & Verde & Marrom & Cônico & C. annuum \\
\hline 48 & CNPH 185 & Brasil & Verde & Vermelha & Cônico & C. annuum \\
\hline 50 & CNPH 40 & Brasil & Verde & Vermelha & Cônico longo & C. апnиит \\
\hline 51 & Corno di Toro & Itália & Verde & Amarelo & Comprida & C. annuит \\
\hline 52 & El Saltenito & México & Verde & Vermelha & Cônico & C. annuum \\
\hline 53 & Flórida VR-4 & U.S.A. & Verde & Vermelha & Cônico & C. annuит \\
\hline 54 & IAC 8 Mogi & Colômbia & Verde & Vermelha & Retangular & C. annuum \\
\hline 55 & ICA \# 12 & Colômbia & Verde & Vermelha & Cônico & C. annuum \\
\hline 56 & ICA \# 131 & Colômbia & Verde & Vermelha & Comprida & C. annuum \\
\hline 57 & ICA \# 132 & Colômbia & Verde & Vermelha & Comprida & C. annuum \\
\hline 58 & ICA \# 218 & Colômbia & Verde & Vermelha & Retangular & C. annuum \\
\hline 59 & Jalapeno & México & Verde & Vermelha & Cônico & C. annuum \\
\hline 60 & Jalapeno & Brasil (SP) & Verde & Vermelha & Retangular & C. annuum \\
\hline 61 & Jalapeno (Cica) n¹ & México & Verde & Vermelha & Comprida & C. annuum \\
\hline 62 & Kan Cluster & U.S.A. & Verde & Vermelha & Cônico & C. annuum \\
\hline 63 & Maalab & Filipinas & Verde & Vermelha & Cônico & C. апnиuт \\
\hline 64 & Marconi & U.S.A. & Verde & Vermelha & Redondo & C. апnиuт \\
\hline 66 & Marrones & Portugal & Verde & Vermelha & Cônico & C. annuum \\
\hline 67 & Mulato Dulce & Portugal & Verde & Marrom & Retangular & C. апnиuт \\
\hline 68 & Mulato V-2 & México & Verde & Vermelha & Retangular & C. annuum \\
\hline 69 & Myr 10 & Brasil & Verde & Vermelha & Retangular & C. annuum \\
\hline 72 & Capsicum annuum 187331 & n.d. ${ }^{1}$ & Verde & Vermelha & Comprida & C. апnиuт \\
\hline 73 & PI 188476 & n.d. & Verde & Vermelha & Cônico & C. annuum \\
\hline
\end{tabular}


Tabela 1 Germoplasma de Capsicum spp., acessos, local de origem, cor do fruto quando verde e quando maduro, formato do fruto e espécie de Capsicum, caracterizado quanto à reação à antracnose em plântulas e em frutos

\begin{tabular}{|c|c|c|c|c|c|c|}
\hline \multirow[t]{2}{*}{$\mathbf{N}^{\circ}$} & \multirow[t]{2}{*}{ Acessos } & \multirow[t]{2}{*}{ Origem } & \multicolumn{2}{|c|}{ Cor do fruto } & \multirow[t]{2}{*}{ Formato } & \multirow[t]{2}{*}{ Espécie } \\
\hline & & & Verde & Maduro & & \\
\hline 75 & Pimenta Ornamental Picante P 01 & Belém-PA & Verde & Vermelha & Cônico & C. annuum \\
\hline 77 & Pimenta Roque & México & Verde & Vermelha & Cônico & C. annuum \\
\hline 80 & $\mathrm{R}-17$ & Filipinas & Verde & Vermelha & Cônico longo & C. annuum \\
\hline 113 & IAC \# 63 & Colômbia & Verde & Vermelha & Cônico & C. annuum \\
\hline 116 & Malagueta & Brasil ( PE) & Verde & Vermelha & Comprida & C. annuum \\
\hline 126 & Pimenta Cheiro & Brasil (AM) & n.d. & n.d. & Cônico & C. annuum \\
\hline 132 & Pimenta Doce IH 1744 & Brasil (AM) & Verde & Vermelha & Cônico compr. & C. annuum \\
\hline 211 & Aji Rojo \# 258 & Bolívia & Verde & Vermelha & Cônico pequen. & C. апnиит \\
\hline 214 & Arivivi \# 261 & Bolívia & Verde & Vermelha & Comprida & C. апnиит \\
\hline 227 & BGH 5122 & Brasil (MG) & Verde & Vermelha & Cônico & C. апnиит \\
\hline 231 & ICA \# 64 & Colômbia & Verde & Vermelha & Cônico & C. annuum \\
\hline 233 & Jalapeno & Brasil (SP) & Verde & Vermelha & Comprida & C. annuum \\
\hline 234 & K homernahu & Bolívia & Verde & Vermelha & Cônico & C. annuum \\
\hline 241 & Pimenta Verde & Braasil (SP) & Verde & Vermelha & Comprida & C. апnиuт \\
\hline 300 & \# 17 & n.d. & Verde & Vermelha & Cônico & C. annuum \\
\hline 302 & BG 3883 & n.d. & Verde & Vermelha & Cônico & C. annuum \\
\hline 303 & BGH 3759 & n.d. & Verde & Vermelha & Cônico & C. annuum \\
\hline 304 & BGH 3887 & n.d. & Verde & Chocolate & Cônico & C. annuum \\
\hline 305 & BG 3757 & n.d. & Verde & Vermelha & Cônico & C. annuum \\
\hline 306 & CNPH 30 & n.d. & Verde & Vermelha & Comprida & C. annuum \\
\hline 307 & CNPH 32 & n.d. & Verde & Vermelha & Retangular & C. annuum \\
\hline 308 & Catie 7300 \# 121 & n.d. & Verde & Vermelha & Retangular & C. annuum \\
\hline 309 & RFG/FAO \# 858 & n.d. & Verde & Vermelha & Cônico & C. annuum \\
\hline 41 & Catie 15388 IH 1651 & Costa Rica & Verde & Amarela & Redondo & C. chinense \\
\hline 105 & Bode & Brasil (PE) & Verde & Amarela & Cônico & C. chinense \\
\hline 110 & Habanera & México & n.d. & n.d. & n.d. & C. chinense \\
\hline 112 & IAC \# 39 & Colômbia & Verde & Vermelha & Cônico & C. chinense \\
\hline 119 & Murupi IH-1490 & Brasil (AM) & Verde & n.d. & Redonda & C. chinense \\
\hline 122 & Pimenta & Brasil (AC) & Verde & Vermelha & Comprida & C. chinense \\
\hline 125 & Pimenta chata & Brasil (PA) & Verde & n.d. & Cônico & C. chinense \\
\hline 130 & Pimenta doce & Brasil (PA) & Verde & Vermelha & Redondo & C. chinense \\
\hline 131 & Pimenta doce & Brasil (PA) & Verde & Vermelha & Redondo & C. chinense \\
\hline
\end{tabular}


Tabela 1 Germoplasma de Capsicum spp., acessos, local de origem, cor do fruto quando verde e quando maduro, formato do fruto e espécie de Capsicum, caracterizado quanto à reação à antracnose em plântulas e em frutos

\begin{tabular}{|c|c|c|c|c|c|c|}
\hline \multirow[t]{2}{*}{$\mathbf{N}^{\circ}$} & \multirow[t]{2}{*}{ Acessos } & \multirow[t]{2}{*}{ Origem } & \multicolumn{2}{|c|}{ Cor do fruto } & \multirow[t]{2}{*}{ Formato } & \multirow[t]{2}{*}{ Espécie } \\
\hline & & & Verde & Maduro & & \\
\hline 133 & Pimenta doce IH-1749 & Brasil (AM) & Verde & Vermelha & Redondo & C. chinense \\
\hline 134 & Pimenta doce IH-1750 & Brasil (AM) & Verde & Vermelha & Comprida & C. chinense \\
\hline 135 & Pimenta doce IH-1758 & Brasil (AM) & Verde & Vermelha & Comprida & C. chinense \\
\hline 136 & Pimenta doce IH-1761 & Brasil (AM) & Verde & Vermelha & Balão retangul. & C. chinense \\
\hline 141 & Pimenta $n^{\circ} 2$ & Brasil (AM) & Verde & Vermelha & Balão & C. chinense \\
\hline 142 & Pimenta $n^{\circ} 5$ & Brasil (AM) & Verde & Vermelha & Balão & C. chinense \\
\hline 143 & Rabo de Мacaco & Brasil (PI) & Verde & Vermelha & Balão retangul. & C. chinense \\
\hline 145 & PI 152225 & n.d. & n.d. & n.d. & n.d. & C. chinense \\
\hline 120 & Murupi IH 1492 INPA & Brasil (AM) & Verde & Vermelha & Comprida & C. baccatum \\
\hline 200 & RFG/FAO \# 553 & Guatemala & Verde & Vermelha & Comprida & C. baccatum \\
\hline 202 & Aji \# 284 & Bolívia & Verde & Amarela & Cônico & C. baccatum \\
\hline 203 & Aji \# 286 & Bolívia & Verde & Vermelha & Comprida & C. baccatum \\
\hline 205 & Aji Amarillo \# 267 & Bolívia & Verde & Vermelha & Cônico médio & C. baccatum \\
\hline 206 & Aji Amarillo \# 269 & Bolívia & Verde & Vermelha & Cônico & C. baccatum \\
\hline 207 & Aji Amarillo \# 60 & Bolívia & Verde & Amarela & Cônico & C. baccatum \\
\hline 208 & Aji Amarillo \# 67 & Bolívia & Verde & Amarela & n.d. & C. baccatum \\
\hline 209 & Aji Amarillo \# 72 & Bolívia & n.d. & n.d. & n.d. & C. baccatum \\
\hline 210 & Aji Limo & Peru & Verde & Vermelha & Comprida & C. baccatum \\
\hline 213 & Arivivi \# 212 & Bolívia & Verde & Vermelha & Comprida & C. baccatum \\
\hline 217 & BGH 1022 & Brasil (MG) & Verde & Vermelha & Cônico pequen. & C. baccatum \\
\hline 218 & BGH 1037 & Brasil (MG) & Verde & Vermelha & Cônico & C. baccatum \\
\hline 220 & BGH 1675 & Brasil (MG) & Verde & Vermelha & Redondo & C. baccatum \\
\hline 221 & BGH 2994 & Brasil (MG) & Verde & Vermelha & Redondo & C. baccatum \\
\hline 222 & BGH 4176 & Brasil (MG) & Verde & Vermelha & Redondo & C. baccatum \\
\hline 223 & BGH 4301 & Brasil (MG) & Verde & Vermelha & Comprida & C. baccatum \\
\hline 224 & BGH 4366 & Brasil (MG) & Verde & Vermelha & Comprida & C. baccatum \\
\hline 225 & BGH 5025 & Brasil (MG) & Verde & Vermelha & Cônico & C. baccatum \\
\hline 228 & Guarnica \# 243 & Bolívia & Verde & Amarela & Comprida & C. baccatum \\
\hline 229 & Babanera BG 592 & México & Verde & Vermelha & Cônico & C. baccatum \\
\hline 232 & ICA \# 65 & Colômbia & Verde & Vermelha & Comprida & C. baccatum \\
\hline 236 & Pimenta & Brasil (SP) & Verde & Vermelha & Balão & C. baccatum \\
\hline 237 & Pimenta Bode balão vermelha & Brasil & Verde & Vermelha & Cônico médio & C. baccatum \\
\hline
\end{tabular}


Tabela 1 Germoplasma de Capsicum spp., acessos, local de origem, cor do fruto quando verde e quando maduro, formato do fruto e espécie de Capsicum, caracterizado quanto à reação à antracnose em plântulas e em frutos

\begin{tabular}{|c|c|c|c|c|c|c|}
\hline \multirow[t]{2}{*}{$\mathbf{N}^{\circ}$} & \multirow[t]{2}{*}{ Acessos } & \multirow[t]{2}{*}{ Origem } & \multicolumn{2}{|c|}{ Cor do fruto } & \multirow[t]{2}{*}{ Formato } & \multirow[t]{2}{*}{ Espécie } \\
\hline & & & Verde & Maduro & & \\
\hline 238 & Pimenta branc piranga & Brasil & Verde & Vermelha & Comprida & C. baccatum \\
\hline 239 & Pimenta Cambuci & Brasil (SP) & Verde & Vermelha & Retang. Cilind. & C. baccatum \\
\hline 240 & Pimenta Coração & Brasil (MT) & Verde & Vermelha & Comprida & C. baccatum \\
\hline 242 & Uchu \# 148 & Bolívia & Verde & Vermelha & Retangular & C. baccatum \\
\hline 243 & Yerba Mala \# 251 & Bolívia & Verde & Vermelha & Cônico & C. baccatum \\
\hline 337 & Pimenta & Brasil (MT) & Verde & Amarela & Cônico média & C. baccatum \\
\hline 340 & ICA \# 60 & n.d. & Verde & Vermelha & Cônico & C. baccatum \\
\hline 342 & Aji 284 & n.d. & Verde & Amarela & Comprido & C. baccatum \\
\hline 402 & Jobito Picante & Venezuela & Verde & Vermelha & Pequena & C. frutescens \\
\hline
\end{tabular}


Tabela 2 Reação de acessos de C. annuum, C. baccatum e C. chinense quanto a ocorrência de antracnose em plântulas, de acordo com a severidade de doença, baseada em uma escala de notas, e incidência, aos 3, 10 e 19 dias após a inoculação (DAI), no primeiro e segundo experimentos de inoculação

\begin{tabular}{|c|c|c|c|c|c|c|c|c|c|c|c|c|c|c|}
\hline \multirow{3}{*}{$\mathbf{N}^{\circ}$} & \multirow{3}{*}{ Acessos } & \multirow{3}{*}{ Espécie } & \multicolumn{6}{|c|}{ Severidade de doença (escala de notas) ${ }^{1}$} & \multicolumn{6}{|c|}{ Incidência (\%) } \\
\hline & & & \multicolumn{2}{|c|}{3 DAI } & \multicolumn{2}{|c|}{10 DAI } & \multicolumn{2}{|c|}{19 DAI } & \multicolumn{2}{|c|}{3 DAI } & \multicolumn{2}{|c|}{10 DAI } & \multicolumn{2}{|c|}{19 DAI } \\
\hline & & & $1^{\circ}$ Exp. & $2^{\circ}$ Exp. & $1^{\circ}$ Exp. & $2^{\circ}$ Exp. & $1^{\circ}$ Exp. & $2^{\circ}$ Exp. & $1^{\circ}$ Exp. & $2^{\circ}$ Exp. & $1^{\circ}$ Exp. & $2^{\circ}$ Exp. & $1^{\circ}$ Exp. & $2^{\circ}$ Exp. \\
\hline 1 & \# 124 & C. апnиuт & 1,0 & - & 1,3 & - & 1,3 & - & 0 & - & 25 & - & 30 & - \\
\hline 2 & \# 132 & C. annuum & 1,1 & - & 1,1 & - & 1,1 & - & 10 & - & 10 & - & 10 & - \\
\hline 3 & \# 138 & C. апnиuт & 1,1 & - & 1,4 & - & 2,0 & - & 5 & - & 25 & - & 40 & - \\
\hline 4 & \# 36 & C. аппиит & 1,1 & - & 1,2 & - & 1,4 & - & 5 & - & 15 & - & 35 & - \\
\hline 5 & \# 5 & C. аппиит & 1,7 & - & 2,9 & - & 3,1 & - & 55 & - & 90 & - & 95 & - \\
\hline 6 & \# 125 & C. annuum & 1,3 & - & 2,5 & - & 2,3 & - & 20 & - & 80 & - & 80 & - \\
\hline 7 & Agronômico 10G & C. annuum & 2,5 & - & 3,7 & - & 3,8 & - & 60 & - & 95 & - & 95 & - \\
\hline 8 & Ancho & C. апnиuт & 1,2 & - & 1,2 & - & 1,2 & - & 15 & - & 20 & - & 20 & - \\
\hline 9 & Ano todo & C. апnиuт & 1,0 & - & 1,1 & - & 1,1 & - & 0 & - & 5 & - & 5 & - \\
\hline 10 & Argentina \# 3 & C. аппиит & 1,3 & 1,0 & 1,5 & 2,9 & 1,5 & 3,0 & 15 & 0 & 30 & 86 & 35 & 93 \\
\hline 12 & BGH 3058 & C. annuum & 1,1 & - & 1,3 & - & 1,9 & - & 10 & - & 30 & - & 75 & - \\
\hline 14 & BGH 3058 & C. аппиит & 1,0 & 1,1 & 1,0 & 3,2 & 1,0 & 3,3 & 0 & 5 & 0 & 65 & 0 & 65 \\
\hline 17 & BGH 3756 & C. апnиuт & 1,0 & 1,0 & 1,3 & 2,0 & 1,3 & 3,8 & 0 & 0 & 25 & 50 & 25 & 83 \\
\hline 18 & BGH 3757 & C. annuит & 1,0 & - & 1,2 & - & 1,2 & - & 0 & - & 15 & - & 20 & - \\
\hline 19 & BGH 3884 & C. апnиит & - & 1,4 & - & 2,6 & - & 3,5 & - & 10 & - & 65 & - & 85 \\
\hline 20 & BGH 3886 & C. annuит & 1,0 & 1,0 & 1,2 & 1,5 & 1,9 & 2,5 & 0 & 0 & 20 & 50 & 65 & 70 \\
\hline 21 & BGH 3890 & C. апnиuт & 1,4 & 1,2 & 1,4 & 2,3 & 1,5 & 2,4 & 20 & 5 & 25 & 45 & 35 & 55 \\
\hline 22 & BGH 3896 & C. annuum & 1,3 & 1,0 & 2,0 & 3,2 & 2,0 & 3,5 & 30 & 0 & 60 & 81 & 60 & 85 \\
\hline 23 & BG 3878 & C. апnиuт & 1,5 & 1,0 & 1,6 & 1,4 & 1,7 & 1,7 & 20 & 0 & 25 & 10 & 35 & 40 \\
\hline 24 & BGH 3978 & C. аппиит & 1,5 & 1,0 & 1,8 & 2,7 & 2,5 & 2,8 & 35 & 0 & 45 & 60 & 85 & 70 \\
\hline 25 & BGH 3464 & C. апnиuт & 1,3 & 1,0 & 1,8 & 2,2 & 2,1 & 2,7 & 33 & 0 & 47 & 60 & 60 & 65 \\
\hline 26 & BGH 3714 & C. annuum & 1,0 & - & 1,1 & - & 1,1 & - & 0 & - & 5 & - & 5 & - \\
\hline 27 & BGH 3756 & C. апnиuт & 1,0 & - & 1,0 & - & 1,8 & - & 0 & - & 0 & - & 70 & - \\
\hline 28 & BGH 3756 & C. апnиuт & 1,3 & - & 1,6 & - & 1,8 & - & 10 & - & 30 & - & 45 & - \\
\hline 29 & BGH 3757 & C. annuum & 1,0 & - & 1,5 & - & 1,6 & - & 0 & - & 30 & - & 35 & - \\
\hline 30 & BGH 3758 & C. annuum & 1,0 & - & 1,0 & - & 1,4 & - & 0 & - & 0 & - & 40 & - \\
\hline 31 & BGH 3881 & C. annuum & 1,0 & - & 1,0 & - & 1,1 & - & 0 & - & 0 & - & 10 & - \\
\hline 32 & BG 3883 & C. апnиuт & 1,0 & - & 1,1 & - & 1,2 & - & 0 & - & 5 & - & 15 & - \\
\hline 33 & BGH 3888 & C. апnиит & 1,0 & 1,0 & 1,0 & 1,2 & 1,1 & 1,4 & 0 & 0 & 0 & 20 & 5 & 40 \\
\hline 34 & BGH 3889 & C. annuum & 1,1 & 1,0 & 1,5 & 3,1 & 1,5 & 3,4 & 5 & 0 & 32 & 70 & 37 & 70 \\
\hline 38 & Calahora & C. annuum & 2,4 & - & 3,8 & - & 3,8 & - & 70 & - & 100 & - & 100 & - \\
\hline 40 & Catarino Cascabel & C. annuит & 1,0 & 1,0 & 1,0 & 1,2 & 1,0 & 1,4 & 0 & 0 & 0 & 20 & 0 & 20 \\
\hline
\end{tabular}


Tabela 2 Reação de acessos de C. annuum, C. baccatum e C. chinense quanto a ocorrência de antracnose em plântulas, de acordo com a severidade de doença, baseada em uma escala de notas, e incidência, aos 3, 10 e 19 dias após a inoculação (DAI), no primeiro e segundo experimentos de inoculação

\begin{tabular}{|c|c|c|c|c|c|c|c|c|c|c|c|c|c|c|}
\hline \multirow{3}{*}{$\mathbf{N}^{\circ}$} & \multirow{3}{*}{ Acessos } & \multirow{3}{*}{ Espécie } & \multicolumn{6}{|c|}{ Severidade de doença (escala de notas) ${ }^{1}$} & \multicolumn{6}{|c|}{ Incidência (\%) } \\
\hline & & & \multicolumn{2}{|c|}{3 DAI } & \multicolumn{2}{|c|}{10 DAI } & \multicolumn{2}{|c|}{19 DAI } & \multicolumn{2}{|c|}{3 DAI } & \multicolumn{2}{|c|}{10 DAI } & \multicolumn{2}{|c|}{19 DAI } \\
\hline & & & $1^{\circ}$ Exp. & $2^{\circ}$ Exp. & $1^{\circ}$ Exp. & $2^{\circ}$ Exp. & $1^{\circ}$ Exp. & $2^{\circ}$ Exp. & $1^{\circ}$ Exp. & $2^{\circ}$ Exp. & $1^{\circ}$ Exp. & $2^{\circ}$ Exp. & $1^{\circ}$ Exp. & $2^{\circ}$ Exp. \\
\hline 42 & Catie 8063 & C. annuum & 1,0 & 1,0 & 1,5 & 1,3 & 1,5 & 1,9 & 0 & 0 & 20 & 25 & 20 & 40 \\
\hline 43 & Chili & C. аппиит & 1,1 & 1,0 & 1,5 & 2,9 & 1,5 & 3,4 & 10 & 0 & 25 & 70 & 30 & 85 \\
\hline 44 & CNPH 144 & C. апnиuт & 1,0 & 1,0 & 1,0 & 1,1 & 1,1 & 1,1 & 0 & 0 & 0 & 5 & 5 & 5 \\
\hline 45 & CNPH 145 & C. annuum & 1,4 & 1,0 & 1,3 & 4,2 & 1,3 & 4,2 & 20 & 0 & 30 & 90 & 30 & 90 \\
\hline 46 & CNPH 146 & C. апnиит & 1,6 & - & 1,7 & - & 2,1 & - & 32 & - & 42 & - & 68 & - \\
\hline 47 & CNPH 162 & C. annuum & 1,4 & 1,0 & 2,3 & 2,3 & 2,2 & 3,1 & 40 & 0 & 75 & 55 & 80 & 65 \\
\hline 48 & CNPH 185 & C. апnиuт & 1,3 & - & 1,3 & - & 1,2 & - & 15 & - & 25 & - & 30 & - \\
\hline 50 & CNPH 40 & C. annuum & - & 1,0 & - & 1,9 & - & 2,2 & - & 0 & - & 30 & - & 45 \\
\hline 52 & El Saltenito & C. annuum & 1,3 & - & 1,5 & - & 1,5 & - & 15 & - & 30 & - & 35 & - \\
\hline 53 & Flórida VR-4 & C. апnиuт & 1,2 & - & 1,6 & - & 1,8 & - & 20 & - & 30 & - & 50 & - \\
\hline 54 & IAC 8 Mogi & C. annuum & 1,3 & - & 2,5 & - & 2,4 & - & 25 & - & 70 & - & 70 & - \\
\hline 55 & ICA \# 12 & C. апnиuт & 1,5 & - & 2,7 & - & 2,9 & - & 30 & - & 80 & - & 80 & - \\
\hline 56 & ICA \# 131 & C. annuum & 1,0 & - & 1,0 & - & 1,0 & - & 0 & - & 0 & - & 0 & - \\
\hline 57 & ICA \# 132 & C. annuum & 1,4 & 1,3 & 1,7 & 2,8 & 2,3 & 2,9 & 25 & 11 & 55 & 78 & 90 & 94 \\
\hline 58 & ICA \# 218 & C. апnиuт & 1,2 & - & 1,9 & - & 1,9 & - & 10 & - & 55 & - & 60 & - \\
\hline 59 & Jalapeno & C. annuum & 1,0 & - & 1,1 & - & 1,2 & - & 0 & - & 10 & - & 15 & - \\
\hline 60 & Jalapeno & C. annuum & 1,4 & - & 2,2 & - & 2,3 & - & 20 & - & 75 & - & 75 & - \\
\hline 61 & $\begin{array}{l}\text { Jalapeno (Cica) } \\
n^{\circ} 1\end{array}$ & C. annuum & 1,1 & - & 1,1 & - & 1,1 & - & 5 & - & 5 & - & 10 & - \\
\hline 62 & Kan Cluster & C. annuum & 2,0 & - & 2,3 & - & 2,5 & - & 55 & - & 80 & - & 85 & - \\
\hline 63 & Maalab & C. апnиит & 1,2 & - & 1,2 & - & 1,2 & - & 5 & - & 5 & - & 5 & - \\
\hline 64 & Marconi & C. annuum & 2,1 & 1,0 & 2,2 & 4,5 & 2,2 & 4,5 & 70 & 0 & 70 & 90 & 90 & 95 \\
\hline 66 & Marrones & C. апnиuт & 1,3 & - & 1,6 & - & 1,9 & - & 15 & - & 30 & - & 35 & - \\
\hline 67 & Mulato Dulce & C. annuum & 1,0 & - & 1,0 & - & 1,2 & - & 0 & - & 0 & - & 15 & - \\
\hline 68 & Mulato V-2 & C. annuum & 1,7 & - & 2,0 & - & 2,0 & - & 20 & - & 50 & - & 55 & - \\
\hline 72 & $\begin{array}{l}\text { Capsicum } \\
\text { annuum } 187331\end{array}$ & C. annuum & 1,5 & 1,0 & 1,8 & 2,5 & 1,8 & 2,8 & 20 & 0 & 30 & 45 & 45 & 45 \\
\hline 73 & PI 188476 & C. апnиит & 1,6 & - & 1,8 & - & 2,3 & - & 55 & - & 65 & - & 85 & - \\
\hline 75 & $\begin{array}{l}\text { Pimenta Ornam. } \\
\text { Picante P } 01\end{array}$ & C. annuum & 1,5 & - & 2,3 & - & 2,4 & - & 50 & - & 65 & - & 65 & - \\
\hline 77 & Pimenta Roque & C. аппиит & 1,9 & - & 2,2 & - & 2,4 & - & 70 & - & 90 & - & 100 & - \\
\hline 80 & $\mathrm{R}-17$ & C. annuum & 1,4 & - & 1,8 & - & 2,4 & - & 20 & - & 30 & - & 85 & - \\
\hline
\end{tabular}


Tabela 2 Reação de acessos de C. annuum, C. baccatum e C. chinense quanto a ocorrência de antracnose em plântulas, de acordo com a severidade de doença, baseada em uma escala de notas, e incidência, aos 3, 10 e 19 dias após a inoculação (DAI), no primeiro e segundo experimentos de inoculação

\begin{tabular}{|c|c|c|c|c|c|c|c|c|c|c|c|c|c|c|}
\hline \multirow{3}{*}{$\mathbf{N}^{\circ}$} & \multirow{3}{*}{ Acessos } & \multirow{3}{*}{ Espécie } & \multicolumn{6}{|c|}{ Severidade de doença (escala de notas) $^{1}$} & \multicolumn{6}{|c|}{ Incidência (\%) } \\
\hline & & & \multicolumn{2}{|c|}{3 DAI } & \multicolumn{2}{|c|}{10 DAI } & \multicolumn{2}{|c|}{19 DAI } & \multicolumn{2}{|c|}{3 DAI } & \multicolumn{2}{|c|}{10 DAI } & \multicolumn{2}{|c|}{19 DAI } \\
\hline & & & $1^{\circ}$ Exp. & $2^{\circ}$ Exp. & $1^{\circ}$ Exp. & $2^{\circ}$ Exp. & $1^{\circ}$ Exp. & $2^{\circ}$ Exp. & $1^{\circ}$ Exp. & $2^{\circ}$ Exp. & $1^{\circ}$ Exp. & $2^{\circ}$ Exp. & $1^{\circ}$ Exp. & $2^{\circ}$ Exp. \\
\hline 113 & IAC \# 63 & C. annuum & 1,0 & - & 1,2 & - & 1,2 & - & 0 & - & 15 & - & 20 & - \\
\hline 116 & Malagueta & C. апnиuт & 1,2 & - & 1,4 & - & 1,9 & - & 15 & - & 35 & - & 80 & - \\
\hline 126 & Pimenta Cheiro & C. annuum & 1,3 & - & 1,5 & - & 1,6 & - & 25 & - & 50 & - & 50 & - \\
\hline 132 & $\begin{array}{l}\text { Pimenta Doce IH } \\
1744\end{array}$ & C. annuum & 1,1 & 1,0 & 1,1 & 1,9 & 1,1 & 2,4 & 5 & 0 & 5 & 40 & 5 & 50 \\
\hline 211 & Aji Rojo \# 258 & C. annuum & 1,8 & - & 2,0 & - & 2,8 & - & 75 & - & 80 & - & 100 & - \\
\hline 214 & Arivivi \# 261 & C. апnиuт & 1,0 & - & 1,0 & - & 1,0 & - & 0 & - & 0 & - & 0 & - \\
\hline 227 & BGH 5122 & C. annuum & 3,4 & 1,0 & 4,3 & 3,3 & 4,3 & 3,6 & 89 & 0 & 95 & 80 & 95 & 90 \\
\hline 231 & ICA \# 64 & C. annuum & 1,1 & - & 1,1 & - & 1,1 & - & 5 & - & 5 & - & 10 & - \\
\hline 233 & Jalapeno & C. аппиит & 1,0 & - & 1,1 & - & 1,1 & - & 0 & - & 10 & - & 10 & - \\
\hline 234 & K homernahu & C. annuum & 1,0 & - & 1,3 & - & 1,5 & - & 0 & - & 10 & - & 15 & - \\
\hline 241 & Pimenta Verde & C. апnиит & 1,0 & 1,0 & 1,2 & 1,4 & 1,4 & 1,5 & 0 & 0 & 15 & 20 & 35 & 35 \\
\hline 300 & \# 17 & C. апnиuт & 1,0 & 1,0 & 1,0 & 1,2 & 1,2 & 1,5 & 0 & 0 & 0 & 5 & 5 & 20 \\
\hline 302 & BG 3883 & C. annuum & 1,5 & - & 1,7 & - & 1,8 & - & 40 & - & 60 & - & 60 & - \\
\hline 303 & BGH 3759 & C. апnиuт & 1,4 & - & 1,5 & - & 2,1 & - & 35 & - & 35 & - & 85 & - \\
\hline 304 & BGH 3887 & C. annuum & 2,1 & - & 3,0 & - & 3,0 & - & 55 & - & 65 & - & 65 & - \\
\hline 305 & BG 3757 & C. annuum & 2,4 & 1,6 & 2,5 & 2,9 & 2,7 & 2,9 & 35 & 60 & 40 & 65 & 45 & 75 \\
\hline 308 & Catie 7300 \# 121 & C. аппиит & - & 1,0 & - & 1,1 & - & 1,3 & - & 0 & - & 5 & - & 15 \\
\hline 309 & RFG/FAO \# 858 & C. annuum & 1,4 & 1,0 & 1,5 & 2,0 & 1,3 & 2,2 & 10 & 0 & 20 & 40 & 15 & 55 \\
\hline 334 & Aji Rojo 265 & C. аппиит & 1,4 & - & 1,6 & - & 1,5 & - & 10 & - & 15 & - & 20 & - \\
\hline 341 & Arivivi \# 142 & C. аnnuит & 1,1 & - & 1,8 & - & 2,1 & - & 5 & - & 45 & - & 75 & - \\
\hline 120 & $\begin{array}{l}\text { Murupi IH } 1492 \\
\text { INPA }\end{array}$ & C. baccatum & 1,2 & - & 1,3 & - & 1,3 & - & 15 & - & 25 & - & 30 & - \\
\hline 200 & RFG/FAO \# 553 & C. baccatum & 1,1 & - & 1,4 & - & 1,6 & - & 5 & - & 25 & - & 25 & - \\
\hline 202 & Aji \# 284 & C. baccatum & 1,6 & 1,0 & 1,8 & 1,7 & 1,8 & 2,7 & 15 & 0 & 30 & 60 & 35 & 75 \\
\hline 203 & Aji \# 286 & C. baccatum & 1,9 & - & 2,5 & - & 2,6 & - & 25 & - & 45 & - & 50 & - \\
\hline 205 & $\begin{array}{l}\text { Aji Amarillo \# } \\
267\end{array}$ & C. baccatum & 1,4 & - & 1,8 & - & 2,1 & - & 30 & - & 40 & - & 60 & - \\
\hline 206 & $\begin{array}{l}\text { Aji Amarillo \# } \\
269\end{array}$ & C. baccatum & 1,5 & 1,0 & 1,8 & 1,2 & 1,8 & 1,3 & 15 & 0 & 30 & 15 & 30 & 25 \\
\hline 207 & Aji Amarillo \# 60 & C. baccatum & - & 1,0 & - & 1,2 & - & 1,7 & - & 0 & - & 20 & - & 25 \\
\hline
\end{tabular}


Tabela 2 Reação de acessos de C. annuum, C. baccatum e C. chinense quanto a ocorrência de antracnose em plântulas, de acordo com a severidade de doença, baseada em uma escala de notas, e incidência, aos 3, 10 e 19 dias após a inoculação (DAI), no primeiro e segundo experimentos de inoculação

\begin{tabular}{|c|c|c|c|c|c|c|c|c|c|c|c|c|c|c|}
\hline \multirow{3}{*}{$\mathbf{N}^{\circ}$} & \multirow{3}{*}{ Acessos } & \multirow{3}{*}{ Espécie } & \multicolumn{6}{|c|}{ Severidade de doença (escala de notas) $^{1}$} & \multicolumn{6}{|c|}{ Incidência (\%) } \\
\hline & & & \multicolumn{2}{|c|}{3 DAI } & \multicolumn{2}{|c|}{10 DAI } & \multicolumn{2}{|c|}{19 DAI } & \multicolumn{2}{|c|}{3 DAI } & \multicolumn{2}{|c|}{10 DAI } & \multicolumn{2}{|c|}{19 DAI } \\
\hline & & & $1^{\circ}$ Exp. & $2^{\circ}$ Exp. & $1^{\circ}$ Exp. & $2^{\circ}$ Exp. & $1^{\circ}$ Exp. & $2^{\circ}$ Exp. & $1^{\circ}$ Exp. & $2^{\circ}$ Exp. & $1^{\circ}$ Exp. & $2^{\circ}$ Exp. & $1^{\circ}$ Exp. & $2^{\circ}$ Exp. \\
\hline 210 & Aji Limo & C. baccatum & 1,4 & - & 1,6 & - & 1,6 & - & 26 & - & 26 & - & 26 & - \\
\hline 213 & Arivivi \# 212 & C. baccatum & 1,3 & - & 1,5 & - & 1,5 & - & 15 & - & 30 & - & 30 & - \\
\hline 217 & BGH 1022 & C. baccatum & 1,4 & - & 1,5 & - & 1,6 & - & 35 & - & 45 & - & 50 & - \\
\hline 220 & BGH 1675 & C. baccatum & 1,0 & 1,0 & 1,0 & 1,6 & 1,1 & 3,1 & 0 & 0 & 0 & 60 & 10 & 75 \\
\hline 221 & BGH 2994 & C. baccatum & 1,0 & - & 1,2 & - & 1,2 & - & 0 & - & 15 & - & 20 & - \\
\hline 225 & BGH 5025 & C. baccatum & 1,0 & 1,0 & 1,1 & 1,4 & 1,1 & 1,7 & 0 & 0 & 5 & 41 & 5 & 41 \\
\hline 228 & Guarnica \# 243 & C. baccatum & 1,4 & - & 1,4 & - & 1,5 & - & 35 & - & 40 & - & 50 & - \\
\hline 229 & Habanera BG592 & C. baccatum & 1,3 & 1,0 & 1,5 & 1,6 & 1,5 & 2,1 & 10 & 0 & 20 & 60 & 20 & 80 \\
\hline 232 & ICA \# 65 & C. baccatum & 1,2 & - & 1,2 & - & 1,5 & - & 5 & - & 5 & - & 35 & - \\
\hline 236 & Pimenta & C. baccatum & 1,1 & 1,0 & 1,2 & 1,3 & 1,1 & 1,3 & 5 & 0 & 20 & 10 & 20 & 15 \\
\hline 237 & $\begin{array}{l}\text { Pimenta Bode } \\
\text { balão vermelha }\end{array}$ & C. baccatum & 1,2 & - & 1,3 & - & 1,3 & - & 20 & - & 20 & - & 30 & - \\
\hline 238 & $\begin{array}{l}\text { Pimenta branca } \\
\text { piranga }\end{array}$ & C. baccatum & 1,1 & - & 1,1 & - & 1,1 & - & 5 & - & 10 & - & 10 & - \\
\hline 239 & $\begin{array}{l}\text { Pimenta } \\
\text { Cambuci }\end{array}$ & C. baccatum & 1,0 & 1,0 & 1,0 & 1,5 & 1,1 & 1,8 & 0 & 0 & 0 & 41 & 10 & 47 \\
\hline 240 & Pimenta Coração & C. baccatum & 1,0 & - & 1,3 & - & 1,4 & - & 0 & - & 25 & - & 38 & - \\
\hline 243 & $\begin{array}{l}\text { Yerba Mala \# } \\
251\end{array}$ & C. baccatum & 1,2 & 1,0 & 1,5 & 1,3 & 1,5 & 1,3 & 20 & 0 & 20 & 25 & 25 & 25 \\
\hline 340 & ICA \# 60 & C. baccatum & 1,3 & 1,0 & 1,4 & 1,0 & 1,4 & 1,1 & 32 & 0 & 32 & 0 & 32 & 5 \\
\hline 342 & Aji 284 & C. baccatum & 1,0 & - & $\overrightarrow{1,1}$ & - & 1,1 & - & 0 & - & 10 & - & 10 & - \\
\hline 112 & IAC \# 39 & C. chinense & - & 1,0 & - & 1,2 & - & 1,7 & - & 0 & - & 20 & - & 55 \\
\hline 122 & Pimenta & C. chinense & 1,7 & 1,0 & 1,9 & 2,8 & 1,9 & 3,1 & 25 & 0 & 35 & 50 & 35 & 65 \\
\hline 125 & Pimenta chata & C. chinense & - & 1,0 & - & 1,8 & - & 2,8 & - & 0 & - & 80 & - & 100 \\
\hline 133 & $\begin{array}{l}\text { Pimenta doce IH- } \\
1749\end{array}$ & C. chinense & - & 1,0 & - & 1,4 & - & 1,4 & - & 0 & - & 20 & - & 20 \\
\hline 135 & $\begin{array}{l}\text { Pimenta doce IH- } \\
1758\end{array}$ & C. chinense & 1,0 & - & 1,4 & - & 1,4 & - & 0 & - & 11 & - & 11 & - \\
\hline 136 & $\begin{array}{l}\text { Pimenta doce IH- } \\
1771\end{array}$ & C. chinense & - & 1,0 & - & 1,7 & - & 2,4 & - & 0 & - & 70 & - & 75 \\
\hline
\end{tabular}


Tabela 2 Reação de acessos de C. annuum, C. baccatum e C. chinense quanto a ocorrência de antracnose em plântulas, de acordo com a severidade de doença, baseada em uma escala de notas, e incidência, aos 3, 10 e 19 dias após a inoculação (DAI), no primeiro e segundo experimentos de inoculação

\begin{tabular}{|c|c|c|c|c|c|c|c|c|c|c|c|c|c|c|}
\hline \multirow{3}{*}{$\mathbf{N}^{\circ}$} & \multirow{3}{*}{ Acessos } & \multirow{3}{*}{ Espécie } & \multicolumn{6}{|c|}{ Severidade de doença (escala de notas) $^{1}$} & \multicolumn{6}{|c|}{ Incidência (\%) } \\
\hline & & & \multicolumn{2}{|c|}{3 DAI } & \multicolumn{2}{|c|}{10 DAI } & \multicolumn{2}{|c|}{19 DAI } & \multicolumn{2}{|c|}{3 DAI } & \multicolumn{2}{|c|}{10 DAI } & \multicolumn{2}{|c|}{19 DAI } \\
\hline & & & $1^{\circ}$ Exp. & $2^{\circ}$ Exp. & $1^{\circ}$ Exp. & $2^{\circ}$ Exp. & $1^{\circ}$ Exp. & $2^{\circ}$ Exp. & $1^{\circ}$ Exp. & $2^{\circ}$ Exp. & $1^{\circ}$ Exp. & $2^{\circ}$ Exp. & $1^{\circ}$ Exp. & $2^{\circ}$ Exp. \\
\hline 142 & Pimenta ${ }^{\circ} 5$ & C. chinense & - & 1,0 & - & 1,5 & - & 1,9 & - & 0 & - & 20 & - & 40 \\
\hline 145 & PI 152225 & C. chinense & 1,5 & 1,4 & 3,8 & 4,0 & 4,5 & 4,2 & 50 & 40 & 100 & 100 & 100 & 100 \\
\hline
\end{tabular}


Tabela 3 Avaliação em plântulas de acordo com a severidade de doença e incidência, aos 3, 10 e 19 dias após a inoculação, das progênies oriundas de retrocruzamentos entre (C. annuum x C. chinense) x C. annuum, geração F4RC1 e [(C. annuum x C. chinense) x C. annuum] x C. annuum, geração F3RC2

\begin{tabular}{|c|c|c|c|c|c|c|c|}
\hline \multirow[t]{2}{*}{ Progênies } & \multirow[t]{2}{*}{ Geração } & \multicolumn{3}{|c|}{ Severidade de doença (escala de notas) ${ }^{1}$} & \multicolumn{3}{|c|}{ Incidência (\%) } \\
\hline & & 3 DAI & 10 DAI & 19 DAI & 3 DAI & 10 DAI & 19 DAI \\
\hline $\mathrm{N}^{\circ} 145$ - PI 152225 & Test. Suscetível & 1,7 & 3,9 & 4,3 & 17 & 98 & 100 \\
\hline PBC 932 & Test. Resistente & 1,0 & 1,0 & 1,0 & 0 & 0 & 0 \\
\hline 3J & F4RC1 & 1,0 & 1,0 & 1,0 & 0 & 0 & 0 \\
\hline $4 \mathrm{~A}$ & F4RC1 & 1,0 & 2,3 & 2,5 & 0 & 42 & 50 \\
\hline 4B & F4RC1 & 1,0 & 1,8 & 1,8 & 0 & 24 & 29 \\
\hline $4 \mathrm{~F}$ & F4RC1 & 1,0 & 3,5 & 3,5 & 0 & 100 & 100 \\
\hline $4 G$ & F4RC1 & 1,0 & 1,6 & 1,6 & 0 & 44 & 44 \\
\hline $4 \mathrm{H}$ & F4RC1 & 1,0 & 2,0 & 2,0 & 0 & 33 & 33 \\
\hline $6 \mathrm{~B}$ & F4RC1 & 1,0 & 1,9 & 2,3 & 0 & 50 & 50 \\
\hline 8B & F4RC1 & 1,0 & 1,7 & 1,7 & 0 & 47 & 47 \\
\hline $8 \mathrm{E}$ & F4RC1 & 1,0 & 2,2 & 2,3 & 0 & 61 & 61 \\
\hline $8 \mathrm{~F}$ & F4RC1 & 1,0 & 1,4 & 1,4 & 0 & 39 & 43 \\
\hline $9 B$ & F4RC1 & 1,0 & 2,7 & 2,7 & 0 & 55 & 57 \\
\hline 9F & F4RC1 & 1,0 & 2,0 & 2,1 & 0 & 28 & 33 \\
\hline 9J & F4RC1 & 1,0 & 1,6 & 1,7 & 0 & 25 & 28 \\
\hline $10 \mathrm{~A}$ & F4RC1 & 1,0 & 1,5 & 1,6 & 0 & 31 & 32 \\
\hline $14 \mathrm{~A}$ & F4RC1 & 1,0 & 1,1 & 1,1 & 0 & 6 & 6 \\
\hline $14 \mathrm{C}$ & F4RC1 & 1,0 & 1,0 & 1,0 & 0 & 0 & 0 \\
\hline 17B & F4RC1 & 1,0 & 1,6 & 1,8 & 0 & 21 & 24 \\
\hline $18 \mathrm{C}$ & F4RC1 & 1,0 & 1,1 & 1,1 & 0 & 2 & 2 \\
\hline $33 \mathrm{~F}$ & F3RC2 & 1,0 & 1,2 & 1,3 & 0 & 12 & 16 \\
\hline $38 G$ & F3RC2 & 1,0 & 1,2 & 1,3 & 0 & 14 & 20 \\
\hline $38 \mathrm{H}$ & F3RC2 & 1,0 & 2,2 & 2,3 & 0 & 40 & 44 \\
\hline
\end{tabular}


Tabela 4 Reação de acessos de Capsicum annuum, C. baccatum, C. chinense e C. frutescens quanto à ocorrência de antracnose em frutos, de acordo com o diâmetro de lesões e incidência aos 3, 7 e 11 dias após a inoculação (DAI), velocidade de crescimento de lesão, período latente e classificação dos acessos, pelo Teste Cluster para agrupamento em classes de resistência, nos dois experimentos de inoculação

\begin{tabular}{|c|c|c|c|c|c|c|c|c|c|c|c|c|c|c|c|c|c|c|}
\hline \multirow[t]{2}{*}{$\mathbf{N}^{\circ}$} & \multirow{3}{*}{ Acesso } & \multirow{2}{*}{ Espécie } & \multicolumn{6}{|c|}{ Diâmetro de lesão $(\mathrm{cm})$} & \multirow{2}{*}{\multicolumn{2}{|c|}{$\begin{array}{l}\text { Vel. Cresc. } \\
(\mathbf{c m} / \mathbf{d i a})^{1}\end{array}$}} & \multirow{2}{*}{\multicolumn{2}{|c|}{$\begin{array}{l}\text { Per. Latente } \\
\text { (DAI) }^{2}\end{array}$}} & \multicolumn{6}{|c|}{ Incidência (\%) } \\
\hline & & & \multicolumn{2}{|c|}{3 DAI } & \multicolumn{2}{|c|}{7 DAI } & \multicolumn{2}{|c|}{11 DAI } & & & & & $3 \mathrm{I}$ & & & & 11 & AI \\
\hline \multicolumn{2}{|c|}{ Resistente } & & $1^{\circ} \mathrm{Ex}$ & $2^{\circ} \mathrm{Ex}$ & $1^{\circ} \mathrm{Ex}$ & $2^{\circ} \mathrm{Ex}$ & $1^{\circ} \mathbf{E x}$ & $2^{\circ} \mathbf{E x}$ & $1^{\circ} \mathbf{E x}$ & $2^{\circ} \mathbf{E x}$ & $1^{\circ} \mathbf{E x}$ & $2^{\circ} \mathbf{E x}$ & $1^{\circ} \mathbf{E x}$ & $2^{\circ} \mathbf{E x}$ & $1^{\circ} \mathbf{E x}$ & $2^{\circ} \mathbf{E x}$ & $1^{\circ} \mathbf{E x}$ & $2^{\circ} \mathrm{Ex}$ \\
\hline 233 & Jalapeno & C. annuum & 0 & - & 0,2 & - & 0,2 & - & 0,02 & - & 7 & - & 0 & - & 42 & - & 50 & - \\
\hline \multicolumn{19}{|c|}{ Moderadamente Resistente } \\
\hline 1 & \# 124 & C. annuum & 0,1 & - & 0,8 & - & 1,3 & - & 0,14 & - & 5 & - & 39 & - & 62 & - & 77 & - \\
\hline 4 & \# 36 & C. апnиuт & 0,2 & 0,2 & 0,9 & 0,6 & 1,4 & 1,5 & 0,16 & 0,16 & 6 & 5 & 39 & 40 & 62 & 80 & 69 & 100 \\
\hline 19 & BGH 3884 & C. апnиuт & 0,0 & 0,1 & 0,6 & 1,2 & 1,4 & 2,1 & 0,18 & 0,28 & 4 & 5 & 0 & 22 & 77 & 89 & 92 & 100 \\
\hline 23 & BG 3878 & C. апnиuт & 0,1 & 0,0 & 0,5 & 0,7 & 1,0 & 1,9 & 0,12 & 0,23 & 5 & 7 & 23 & 0 & 46 & 67 & 54 & 100 \\
\hline 40 & $\begin{array}{l}\text { Catarino } \\
\text { Cascabel }\end{array}$ & C. апnиuт & 0,1 & 0,2 & 0,5 & 1,1 & 0,7 & 2,3 & 0,08 & 0,26 & 5 & 5 & 27 & 60 & 27 & 80 & 27 & 100 \\
\hline 42 & Catie 8063 & C. апnиuт & 0,1 & 0,0 & 0,6 & 1,2 & 1,1 & 1,9 & 0,12 & 0,24 & 5 & 7 & 31 & 0 & 46 & 80 & 46 & 80 \\
\hline 52 & El Saltenito & C. апnиuт & 0,1 & 0,0 & 0,3 & 0,4 & 0,6 & 2,0 & 0,06 & 0,25 & 5 & 7 & 15 & 0 & 23 & 43 & 31 & 100 \\
\hline 56 & ICA \# 131 & C. annuum & 0,1 & 0,0 & 0,5 & 0,6 & 1,0 & 1,6 & 0,12 & 0,20 & 6 & 5 & 23 & 0 & 54 & 75 & 69 & 75 \\
\hline 61 & $\begin{array}{l}\text { Jalapeno (Cica) } \\
n^{\circ} 1\end{array}$ & C. апnиuт & 0,0 & 0,1 & 0,2 & 0,8 & 0,6 & 1,8 & 0,07 & 0,21 & 7 & 5 & 23 & 27 & 46 & 73 & 46 & 80 \\
\hline 67 & Mulato Dulce & C. апnиит & 0,0 & 0,2 & 0,5 & 1,7 & 1,6 & 3,1 & 0,20 & 0,36 & 5 & 5 & 0 & 33 & 40 & 100 & 70 & 100 \\
\hline 72 & $\begin{array}{l}\text { Capsicum } \\
\text { annuum } 187331\end{array}$ & C. апnиuт & 0,1 & 0,0 & 0,5 & 0,3 & 0,9 & 1,3 & 0,10 & 0,17 & 5 & 5 & 39 & 7 & 46 & 33 & 46 & 80 \\
\hline 73 & PI 188476 & C. апnиuт & 0,1 & 0,2 & 0,6 & 1,1 & 1,3 & 1,6 & 0,15 & 0,18 & 5 & 5 & 23 & 50 & 54 & 64 & 69 & 79 \\
\hline 214 & Arivivi \# 261 & C. annuum & 0,1 & - & 0,3 & - & 0,6 & - & 0,07 & - & 5 & - & 17 & - & 25 & - & 33 & - \\
\hline 302 & BG 3883 & C. annuum & 0,0 & 0,2 & 0,4 & 1,5 & 1,0 & 2,3 & 0,12 & 0,27 & 5 & 5 & 0 & 44 & 42 & 94 & 67 & 100 \\
\hline \multicolumn{19}{|c|}{ Moderadamente Suscetível } \\
\hline 2 & \# 132 & C. annuum & 0,3 & - & 1,6 & - & 2,2 & - & 0,23 & - & 5 & - & 62 & - & 100 & - & 100 & - \\
\hline 3 & \# 138 & C. апnиuт & 0 & - & 1,2 & - & 2,3 & - & 0,29 & - & 5 & - & 8 & - & 92 & - & 92 & - \\
\hline 5 & \# 5 & C. апnиuт & 0,5 & - & 1,5 & - & 1,9 & - & 0,18 & - & 5 & - & 92 & - & 100 & - & 100 & - \\
\hline 6 & \# 125 & C. annuum & 0,4 & - & 1,7 & - & 2,5 & - & 0,27 & - & 4 & - & 58 & - & 92 & - & 92 & - \\
\hline 7 & Agronômico 10G & C. апnиит & 0,5 & - & 1,6 & - & 2,4 & - & 0,23 & - & 6 & - & 100 & - & 100 & - & 100 & - \\
\hline 9 & Ano todo & C. апnиuт & 0,1 & - & 1,1 & - & 2 & - & 0,25 & - & 5 & - & 15 & - & 77 & - & 92 & - \\
\hline 10 & Argentina \# 3 & C. annuum & 0,3 & - & 1,6 & - & 2,6 & - & 0,29 & - & 5 & - & 69 & - & 92 & - & 92 & - \\
\hline 18 & BGH 3757 & C. апnиuт & 0,2 & - & 1,4 & - & 2,2 & - & 0,24 & - & 5 & - & 62 & - & 100 & - & 100 & - \\
\hline 20 & BGH 3886 & C. апnиuт & 0,4 & - & 1,2 & - & 1,9 & - & 0,19 & - & 6 & - & 77 & - & 92 & - & 100 & - \\
\hline 24 & BGH 3978 & C. апnиuт & 0,4 & - & 1,7 & - & 2,6 & - & 0,28 & - & 5 & - & 77 & - & 100 & - & 100 & - \\
\hline
\end{tabular}


Tabela 4 Reação de acessos de Capsicum annuum, C. baccatum, C. chinense e C. frutescens quanto à ocorrência de antracnose em frutos, de acordo com o diâmetro de lesões e incidência aos 3, 7 e 11 dias após a inoculação (DAI), velocidade de crescimento de lesão, período latente e classificação dos acessos, pelo Teste Cluster para agrupamento em classes de resistência, nos dois experimentos de inoculação

\begin{tabular}{|c|c|c|c|c|c|c|c|c|c|c|c|c|c|c|c|c|c|c|}
\hline \multirow{3}{*}{$\mathbf{N}^{\circ}$} & \multirow{3}{*}{ Acesso } & \multirow{3}{*}{ Espécie } & \multicolumn{6}{|c|}{ Diâmetro de lesão (cm) } & \multirow{2}{*}{\multicolumn{2}{|c|}{$\begin{array}{l}\text { Vel. Cresc. } \\
\text { (cm/dia) }\end{array}$}} & \multirow{2}{*}{\multicolumn{2}{|c|}{$\begin{array}{l}\text { Per. Latente } \\
\text { (DAI) }^{2}\end{array}$}} & \multicolumn{6}{|c|}{ Incidência (\%) } \\
\hline & & & \multicolumn{2}{|c|}{3 DAI } & \multicolumn{2}{|c|}{7 DAI } & \multicolumn{2}{|c|}{11 DAI } & & & & & 3 D & & & & $11 \mathrm{I}$ & AI \\
\hline & & & $1^{\circ} \mathrm{Ex}$ & $2^{\circ} \mathbf{E x}$ & $1^{\circ} \mathbf{E x}$ & $2^{\circ} \mathbf{E x}$ & $1^{\circ} \mathbf{E x}$ & $2^{\circ} \mathrm{Ex}$ & $1^{\circ} \mathbf{E x}$ & $2^{\circ} \mathrm{Ex}$ & $1^{\circ} \mathbf{E x}$ & $2^{\circ} \mathbf{E x}$ & $1^{\circ} \mathrm{Ex}$ & $2^{\circ} \mathbf{E x}$ & $1^{\circ} \mathrm{Ex}$ & $2^{\circ} \mathbf{E x}$ & $1^{\circ} \mathrm{Ex}$ & $2^{\circ} \mathrm{Ex}$ \\
\hline 26 & BGH 3714 & C. апnиuт & 0,1 & - & 1,1 & - & 2,1 & - & 0,24 & - & 5 & - & 42 & - & 100 & - & 100 & - \\
\hline 27 & BGH 3756 & С. аппиит & 0,4 & - & 1,8 & - & 2,6 & - & 0,28 & - & 5 & - & 85 & - & 100 & - & 100 & - \\
\hline 30 & BGH 3758 & C. annuum & 0,2 & - & 1,6 & - & 2,6 & - & 0,3 & - & 6 & - & 31 & - & 77 & - & 100 & - \\
\hline 31 & BGH 3881 & C. апnиит & 0,5 & - & 1,5 & - & 2,4 & - & 0,24 & - & 5 & - & 100 & - & 100 & - & 100 & - \\
\hline 32 & BG 3883 & C. апnиит & 0,2 & - & 1,2 & - & 2,1 & - & 0,24 & - & 5 & - & 46 & - & 69 & - & 85 & - \\
\hline 33 & BGH 3888 & C. annuum & 0,2 & - & 1,3 & - & 2,2 & - & 0,25 & - & 5 & - & 54 & - & 92 & - & 92 & - \\
\hline 34 & BGH 3889 & С. апnиит & 0,2 & - & 1,3 & - & 2,2 & - & 0,25 & - & 5 & - & 54 & - & 85 & - & 100 & - \\
\hline 43 & Chili & C. апnиuт & 0,8 & - & 1,6 & - & 2,5 & - & 0,21 & - & 5 & - & 92 & - & 100 & - & 100 & - \\
\hline 44 & CNPH 144 & C. апnиuт & 0,1 & 0,5 & 0,7 & 1,8 & 1,8 & 2,6 & 0,22 & 0,26 & 5 & 5 & 23 & 82 & 46 & 100 & 69 & 100 \\
\hline 46 & CNPH 146 & C. annuum & 0,4 & - & 1,8 & - & 2,4 & - & 0,26 & - & 3 & - & 85 & - & 100 & - & 100 & - \\
\hline 47 & CNPH 162 & С. аппиит & 0,5 & - & 1,5 & - & 2,2 & - & 0,21 & - & 5 & - & 85 & - & 100 & - & 100 & - \\
\hline 50 & CNPH 40 & С. аппиит & 0,5 & - & 1,2 & - & 2,2 & - & 0,22 & - & 4 & - & 77 & - & 92 & - & 100 & - \\
\hline 53 & Flórida VR-4 & C. апnиuт & 0,7 & - & 1,8 & - & 2,4 & - & 0,22 & - & 4 & - & 85 & - & 100 & - & 100 & - \\
\hline 55 & ICA \# 12 & C. annuum & 0,5 & - & 1,5 & - & 2,5 & - & 0,25 & - & 5 & - & 92 & - & 100 & - & 100 & - \\
\hline 57 & ICA \# 132 & C. апnиuт & 0,2 & - & 1,4 & - & 2 & - & 0,22 & - & 5 & - & 46 & - & 100 & - & 100 & - \\
\hline 59 & Jalapeno & C. апnиит & 0 & - & 1,1 & - & 2,1 & - & 0,25 & - & 5 & - & 8 & - & 85 & - & 85 & - \\
\hline 60 & Jalapeno & C. апnиuт & 0,1 & - & 1,4 & - & 2,4 & - & 0,29 & - & 5 & - & 39 & - & 77 & - & 92 & - \\
\hline 62 & Kan Cluster & C. annuum & 0,3 & - & 1,5 & - & 2,3 & - & 0,26 & - & 5 & - & 77 & - & 100 & - & 100 & - \\
\hline 63 & Maalab & C. апnиuт & 0,4 & - & 1,8 & - & 2,4 & - & 0,26 & - & 5 & - & 92 & - & 100 & - & 100 & - \\
\hline 68 & Mulato V-2 & С. аппиит & 0,1 & - & 1,7 & - & 2,6 & - & 0,32 & - & 5 & & 46 & - & 100 & - & 100 & - \\
\hline 75 & $\begin{array}{l}\text { Pimenta Ornam. } \\
\text { Picante P } 01\end{array}$ & C. annuum & 0,4 & - & 1,6 & - & 2,4 & - & 0,25 & - & 5 & - & 77 & - & 92 & - & 100 & - \\
\hline 77 & Pimenta Roque & C. апnиит & 0,6 & - & 1,7 & - & 2,5 & - & 0,25 & - & 5 & - & 100 & - & 100 & - & 100 & - \\
\hline 80 & $\mathrm{R}-17$ & C. апnиит & 0,5 & - & 1,4 & - & 2,1 & - & 0,21 & - & 5 & - & 85 & - & 100 & - & 100 & - \\
\hline 113 & IAC \# 63 & С. аппиит & 0 & 0,5 & 0,9 & 2,2 & 1,8 & 3 & 0,24 & 0,32 & 5 & 3 & 0 & 75 & 90 & 100 & 80 & 100 \\
\hline 116 & Malagueta & C. апnиuт & 0,4 & - & 1,6 & - & 2,2 & - & 0,24 & - & 6 & - & 85 & - & 100 & - & 100 & - \\
\hline 126 & Pimenta Cheiro & C. annuum & 0,4 & - & 1,4 & - & 2 & - & 0,2 & - & 5 & - & 85 & - & 92 & - & 100 & - \\
\hline 132 & $\begin{array}{l}\text { Pimenta Doce } \\
\text { IH } 1744\end{array}$ & C. апnиuт & 0,2 & 0,3 & 1,1 & 1,6 & 1,9 & 2,6 & 0,21 & 0,29 & 5 & 5 & 46 & 38 & 77 & 94 & 85 & 94 \\
\hline 211 & Aji Rojo \# 258 & C. апnиит & 0,7 & - & 1,6 & - & 2,1 & - & 0,18 & - & 4 & - & 92 & - & 100 & - & 100 & - \\
\hline
\end{tabular}


Tabela 4 Reação de acessos de Capsicum annuum, C. baccatum, C. chinense e C. frutescens quanto à ocorrência de antracnose em frutos, de acordo com o diâmetro de lesões e incidência aos 3, 7 e 11 dias após a inoculação (DAI), velocidade de crescimento de lesão, período latente e classificação dos acessos, pelo Teste Cluster para agrupamento em classes de resistência, nos dois experimentos de inoculação

\begin{tabular}{|c|c|c|c|c|c|c|c|c|c|c|c|c|c|c|c|c|c|c|}
\hline \multirow{3}{*}{$\mathbf{N}^{\circ}$} & \multirow{3}{*}{ Acesso } & \multirow{3}{*}{ Espécie } & \multicolumn{6}{|c|}{ Diâmetro de lesão (cm) } & \multirow{2}{*}{\multicolumn{2}{|c|}{$\begin{array}{l}\text { Vel. Cresc. } \\
\text { (cm/dia) }{ }^{1}\end{array}$}} & \multirow{2}{*}{\multicolumn{2}{|c|}{$\begin{array}{l}\text { Per. Latente } \\
\text { (DAI) }^{2}\end{array}$}} & \multicolumn{6}{|c|}{ Incidência (\%) } \\
\hline & & & \multicolumn{2}{|c|}{3 DAI } & \multicolumn{2}{|c|}{7 DAI } & \multicolumn{2}{|c|}{11 DAI } & & & & & $3 \mathrm{I}$ & & & & 11 & AI \\
\hline & & & $1^{\circ} \mathrm{Ex}$ & $2^{\circ} \mathbf{E x}$ & $1^{\circ} \mathrm{Ex}$ & $2^{\circ} \mathbf{E x}$ & $1^{\circ} \mathbf{E x}$ & $2^{\circ} \mathrm{Ex}$ & $1^{\circ} \mathrm{Ex}$ & $2^{\circ} \mathrm{Ex}$ & $1^{\circ} \mathbf{E x}$ & $2^{\circ} \mathbf{E x}$ & $1^{\circ} \mathbf{E x}$ & $2^{\circ} \mathbf{E x}$ & $1^{\circ} \mathrm{Ex}$ & $2^{\circ} \mathbf{E x}$ & $1^{\circ} \mathbf{E x}$ & $2^{\circ} \mathrm{Ex}$ \\
\hline 231 & ICA \# 64 & C. апnиит & 0,2 & - & 1,5 & - & 2 & - & 0,23 & - & 4 & - & 46 & - & 92 & - & 92 & - \\
\hline 300 & \# 17 & C. annuum & 0,2 & _ & 1,5 & - & 2,3 & - & 0,26 & - & 5 & - & 54 & - & 100 & - & 100 & _ \\
\hline 303 & BGH 3759 & C. апnиuт & 0,1 & - & 1,1 & - & 2 & - & 0,24 & - & 5 & - & 31 & - & 100 & - & 100 & - \\
\hline 308 & Catie 7300 \# 121 & C. annuum & 0,1 & - & 1,2 & - & 2,4 & - & 0,28 & - & 3 & - & 15 & - & 92 & - & 100 & _ \\
\hline 309 & RFG/FAO \# 858 & C. annuum & 0,5 & - & 1,8 & - & 2,7 & - & 0,28 & - & 4 & - & 77 & - & 100 & - & 100 & - \\
\hline 341 & Arivivi \# 142 & C. апnиuт & 0,6 & - & 1,5 & - & 2,1 & - & 0,19 & - & 4 & - & 92 & - & 100 & - & 100 & - \\
\hline \multicolumn{19}{|c|}{ Suscetível } \\
\hline 8 & Ancho & C. annuит & 0,4 & - & 1,9 & - & 2,9 & - & 0,32 & - & 6 & - & 75 & - & 100 & - & 100 & - \\
\hline 14 & BGH 3058 & C. annuum & 0,3 & - & 1.6 & _- & 2,9 & - & 0,32 & _- & 4 & _ & 46 & - & 85 & - & 100 & _- \\
\hline 17 & BGH 3756 & C. annuum & 0,6 & - & 2,2 & - & 3,2 & - & 0,33 & - & 4 & - & 100 & - & 100 & - & 100 & - \\
\hline 21 & BGH 3890 & C. annuum & 0,7 & - & 2,3 & - & 3,4 & - & 0,33 & - & 4 & - & 92 & - & 100 & - & 100 & - \\
\hline 22 & BGH 3896 & C. annuum & 0,1 & 0,2 & 1,8 & 1,8 & 3,2 & 3,2 & 0,39 & 0,38 & 5 & 5 & 22 & 13 & 89 & 93 & 89 & 100 \\
\hline 25 & BGH 3464 & C. annuum & 0,3 & - & 1,8 & - & 3,2 & - & 0,37 & - & 6 & - & 67 & - & 100 & - & 100 & - \\
\hline 28 & BGH 3756 & C. апnиuт & 0,4 & - & 2 & - & 3,1 & - & 0,33 & - & 5 & - & 92 & - & 100 & - & 100 & - \\
\hline 29 & BGH 3757 & C. annuum & 0,4 & - & 1,7 & - & 2,8 & - & 0,3 & - & 4 & - & 69 & - & 85 & - & 85 & - \\
\hline 36 & BGH 4016 & C. annuum & 0,2 & 0,2 & 1,7 & 2,2 & 3,2 & 3,9 & 0,38 & 0,47 & 6 & 3 & 57 & 33 & 100 & 100 & 100 & 100 \\
\hline 38 & Calahora & C. annuum & 0,6 & - & 2,2 & - & 3,4 & - & 0,35 & - & 4 & - & 77 & - & 92 & - & 100 & - \\
\hline 45 & CNPH 145 & C. annuum & 0,2 & - & 1,7 & - & 2,9 & - & 0,34 & - & 4 & - & 31 & - & 100 & - & 100 & - \\
\hline 48 & CNPH 185 & C. annuum & 0,3 & - & 1,8 & - & 3 & - & 0,33 & - & 5 & - & 69 & - & 92 & - & 100 & - \\
\hline 51 & Corno di Toro & C. annuum & 0,2 & 0,1 & 1,9 & 2 & 3,4 & 3,5 & 0,4 & 0,42 & 4 & 3 & 31 & 25 & 100 & 100 & 100 & 100 \\
\hline 227 & BGH 5122 & C. annuum & 0,5 & - & 1,8 & - & 2,8 & - & 0,29 & - & 5 & - & 100 & - & 100 & - & 100 & - \\
\hline 234 & K homernahu & C. апnиuт & 0,5 & - & 2 & - & 3,1 & - & 0,31 & - & 4 & - & 62 & - & 92 & - & 100 & - \\
\hline 305 & BG 3757 & C. annuum & 0,8 & - & 2,2 & - & 3,2 & - & 0,31 & - & 4 & - & 100 & - & 100 & - & 100 & - \\
\hline 307 & CNPH 32 & C. annuum & 0,2 & - & 1,8 & - & 2,9 & - & 0,34 & - & 5 & - & 46 & - & 92 & - & 100 & - \\
\hline 334 & Aji Rojo 265 & C. аппиит & 0,5 & - & 1,8 & - & 2,8 & - & 0,29 & - & 4 & - & 85 & - & 100 & - & 100 & - \\
\hline \multicolumn{19}{|c|}{ Altamente Suscetível } \\
\hline 11 & Avelar & C. аппиит & 0,5 & 0,3 & 2,4 & 2,4 & 4,2 & 3,9 & 0,46 & 0,44 & 4 & 5 & 77 & 73 & 100 & 100 & 100 & 100 \\
\hline 12 & BGH 3058 & C. annuum & 0,6 & - & 2,1 & - & 3,7 & - & 0,39 & - & 4 & - & 91 & - & 100 & - & 100 & - \\
\hline 13 & BGH 3464 & C. annuum & 0,5 & - & 2,3 & - & 4 & - & 0,43 & - & 4 & - & 92 & - & 100 & - & 100 & - \\
\hline 15 & BGH 3743 & C. annuum & 0,7 & - & 2.6 & _- & 4 & - & 0,41 & - & 4 & - & 100 & - & 100 & - & 100 & _ \\
\hline
\end{tabular}


Tabela 4 Reação de acessos de Capsicum annuum, C. baccatum, C. chinense e C. frutescens quanto à ocorrência de antracnose em frutos, de acordo com o diâmetro de lesões e incidência aos 3, 7 e 11 dias após a inoculação (DAI), velocidade de crescimento de lesão, período latente e classificação dos acessos, pelo Teste Cluster para agrupamento em classes de resistência, nos dois experimentos de inoculação

\begin{tabular}{|c|c|c|c|c|c|c|c|c|c|c|c|c|c|c|c|c|c|c|}
\hline \multirow{3}{*}{$\mathbf{N}^{\circ}$} & \multirow{3}{*}{ Acesso } & \multirow{3}{*}{ Espécie } & \multicolumn{6}{|c|}{ Diâmetro de lesão (cm) } & \multirow{2}{*}{\multicolumn{2}{|c|}{$\begin{array}{l}\text { Vel. Cresc. } \\
\text { (cm/dia) }\end{array}$}} & \multirow{2}{*}{\multicolumn{2}{|c|}{$\begin{array}{l}\text { Per. Latente } \\
\text { (DAI) }^{2}\end{array}$}} & \multicolumn{6}{|c|}{ Incidência (\%) } \\
\hline & & & \multicolumn{2}{|c|}{3 DAI } & \multicolumn{2}{|c|}{7 DAI } & \multicolumn{2}{|c|}{11 DAI } & & & & & \multicolumn{2}{|c|}{3 DAI } & \multicolumn{2}{|c|}{7 DAI } & \multicolumn{2}{|c|}{11 DAI } \\
\hline & & & $1^{\circ} \mathrm{Ex}$ & $2^{\circ} \mathbf{E x}$ & $1^{\circ} \mathbf{E x}$ & $2^{\circ} \mathbf{E x}$ & $1^{\circ} \mathrm{Ex}$ & $2^{\circ} \mathrm{Ex}$ & $1^{\circ} \mathrm{Ex}$ & $2^{\circ} \mathrm{Ex}$ & $1^{\circ} \mathbf{E x}$ & $2^{\circ} \mathbf{E x}$ & $1^{\circ} \mathbf{E x}$ & $2^{\circ} \mathbf{E x}$ & $1^{\circ} \mathrm{Ex}$ & $2^{\circ} \mathbf{E x}$ & $1^{\circ} \mathrm{Ex}$ & $2^{\circ} \mathrm{Ex}$ \\
\hline 16 & BGH 3744 & C. апnиuт & 0,6 & & 2,3 & - & 3,7 & - & 0,39 & - & 4 & - & 75 & - & 100 & & 100 & - \\
\hline 39 & Caprioglio & C. аппиит & 0,9 & 0,2 & 2,8 & 2,2 & 3,9 & 3,7 & 0,36 & 0,44 & 4 & 5 & 100 & 38 & 100 & 100 & 100 & 100 \\
\hline 54 & IAC 8 Mogi & C. annuum & 0,2 & 0,1 & 2,2 & 1,7 & 3,9 & 3,1 & 0,47 & 0,37 & 3 & 5 & 57 & 55 & 100 & 100 & 100 & 100 \\
\hline 58 & ICA \# 218 & C. annuum & 0,6 & 0,4 & 2,7 & 2,2 & 4,1 & 2,9 & 0,44 & 0,34 & 4 & 3 & 92 & 50 & 100 & 100 & 100 & 100 \\
\hline 64 & Marconi & C. апnиuт & 1,0 & 0,2 & 2,5 & 1,5 & 3,7 & 2,5 & 0,34 & 0,28 & 4 & 5 & 100 & 42 & 100 & 89 & 100 & 100 \\
\hline 66 & Marrones & C. аппиит & 0,8 & - & 2,5 & - & 3,8 & - & 0,38 & - & 4 & - & 100 & - & 100 & - & 100 & - \\
\hline 69 & Myr 10 & C. апnиuт & 0,4 & - & 2,3 & - & 3,8 & - & 0,42 & - & 6 & - & 80 & - & 100 & - & 100 & - \\
\hline 241 & Pimenta Verde & C. annuит & 0,8 & 0,1 & 2,4 & 1,2 & 3,5 & 2 & 0,34 & 0,24 & 4 & 5 & 80 & 29 & 100 & 94 & 100 & 100 \\
\hline 304 & BGH 3887 & C. annuum & 0,7 & 0,3 & 2,3 & 2,1 & 3,6 & 3,4 & 0,35 & 0,38 & 6 & 3 & 100 & 88 & 100 & 100 & 100 & 100 \\
\hline \multicolumn{19}{|c|}{ Resistente } \\
\hline 222 & BGH 4176 & C. baccatum & 0,1 & - & 0,6 & - & 0,8 & - & 0,08 & - & 5 & - & 8 & - & 39 & - & 54 & - \\
\hline \multicolumn{19}{|c|}{ Intermediário } \\
\hline 200 & RFG/FAO \# 553 & C. baccatum & 0 & - & 0,7 & - & 1,8 & - & 0,23 & - & 5 & - & 0 & - & 62 & - & 100 & - \\
\hline 202 & Aji \# 284 & C. baccatum & 0,1 & 0 & 0,6 & 0,4 & 1,6 & 1,7 & 0,19 & 0,21 & 5 & 5 & 15 & 0 & 54 & 55 & 85 & 100 \\
\hline 205 & $\begin{array}{l}\text { Aji Amarillo } \\
\text { \# } 267\end{array}$ & C. baccatum & 0,1 & 0,1 & 0,5 & 1,2 & 1,4 & 2,1 & 0,17 & 0,26 & 5 & 5 & 8 & 19 & 62 & 100 & 77 & 100 \\
\hline 206 & $\begin{array}{l}\text { Aji Amarillo } \\
\text { \# } 269\end{array}$ & C. baccatum & 0 & 0 & 0,6 & 1,3 & 1,6 & 2,4 & 0,2 & 0,3 & 5 & 5 & 0 & 13 & 54 & 100 & 77 & 100 \\
\hline 207 & $\begin{array}{l}\text { Aji Amarillo \# } \\
60\end{array}$ & C. baccatum & - & 0 & - & 0,9 & - & 2 & - & 0,25 & - & 7 & - & 0 & - & 86 & - & 100 \\
\hline 209 & Aji Amarillo \# 72 & C. baccatum & 0,1 & - & 0,5 & - & 1,4 & - & 0,17 & - & 5 & - & 8 & - & 46 & - & 92 & - \\
\hline 210 & Aji Limo & C. baccatum & 0,1 & - & 1,1 & - & 2,3 & - & 0,27 & - & 3 & - & 31 & - & 85 & - & 92 & - \\
\hline 217 & BGH 1022 & C. baccatum & 0,1 & - & 0,7 & - & 1,5 & - & 0,18 & - & 5 & - & 23 & - & 77 & - & 77 & - \\
\hline 220 & BGH 1675 & C. baccatum & 0,1 & 0,3 & 0,8 & 1,7 & 1,3 & 2,3 & 0,16 & 0,27 & 5 & 3 & 23 & 57 & 69 & 100 & 69 & 100 \\
\hline 224 & BGH 4366 & C. baccatum & 0 & - & 0,5 & - & 1,7 & - & 0,21 & - & 5 & - & 0 & - & 54 & - & 92 & - \\
\hline 225 & BGH 5025 & C. baccatum & 0,2 & - & 1,1 & - & 2,1 & - & 0,24 & - & 3 & - & 62 & - & 92 & - & 92 & - \\
\hline 228 & Guarnica \# 243 & C. baccatum & 0,1 & - & 1,2 & - & 2,3 & - & 0,27 & - & 5 & - & 39 & - & 85 & - & 92 & - \\
\hline 237 & $\begin{array}{l}\text { Pimenta Bode } \\
\text { balão vermelha }\end{array}$ & C. baccatum & 0,1 & - & 0,6 & - & 1,9 & - & 0,23 & - & 5 & - & 15 & - & 62 & - & 100 & - \\
\hline
\end{tabular}


Tabela 4 Reação de acessos de Capsicum annuum, C. baccatum, C. chinense e C. frutescens quanto à ocorrência de antracnose em frutos, de acordo com o diâmetro de lesões e incidência aos 3, 7 e 11 dias após a inoculação (DAI), velocidade de crescimento de lesão, período latente e classificação dos acessos, pelo Teste Cluster para agrupamento em classes de resistência, nos dois experimentos de inoculação.

\begin{tabular}{|c|c|c|c|c|c|c|c|c|c|c|c|c|c|c|c|c|c|c|}
\hline \multirow{3}{*}{$\mathbf{N}^{\circ}$} & \multirow{3}{*}{ Acesso } & \multirow{3}{*}{ Espécie } & \multicolumn{6}{|c|}{ Diâmetro de lesão (cm) } & \multirow{2}{*}{\multicolumn{2}{|c|}{$\begin{array}{l}\text { Vel. Cresc. } \\
\text { (cm/dia) }\end{array}$}} & \multirow{2}{*}{\multicolumn{2}{|c|}{$\begin{array}{l}\text { Per. Latente } \\
\text { (DAI) }^{2}\end{array}$}} & \multicolumn{6}{|c|}{ Incidência (\%) } \\
\hline & & & \multicolumn{2}{|c|}{3 DAI } & \multicolumn{2}{|c|}{7 DAI } & \multicolumn{2}{|c|}{11 DAI } & & & & & \multicolumn{2}{|c|}{3 DAI } & \multicolumn{2}{|c|}{7 DAI } & \multicolumn{2}{|c|}{11 DAI } \\
\hline & & & $1^{\circ} \mathrm{Ex}$ & $2^{\circ} \mathbf{E x}$ & $1^{\circ} \mathbf{E x}$ & $2^{\circ} \mathbf{E x}$ & $1^{\circ} \mathrm{Ex}$ & $2^{\circ} \mathrm{Ex}$ & $1^{\circ} \mathrm{Ex}$ & $2^{\circ} \mathrm{Ex}$ & $1^{\circ} \mathbf{E x}$ & $2^{\circ} \mathbf{E x}$ & $1^{\circ} \mathrm{Ex}$ & $2^{\circ} \mathbf{E x}$ & $1^{\circ} \mathrm{Ex}$ & $2^{\circ} \mathbf{E x}$ & $1^{\circ} \mathbf{E x}$ & $2^{\circ} \mathbf{E x}$ \\
\hline 238 & $\begin{array}{l}\text { Pimenta branca } \\
\text { piranga }\end{array}$ & C. baccatum & 0 & - & 0,8 & - & 1,9 & - & 0,24 & - & 5 & - & 0 & - & 85 & - & 100 & - \\
\hline 239 & $\begin{array}{l}\text { Pimenta } \\
\text { Cambuci }\end{array}$ & C. baccatum & 0 & 0 & 0,4 & 0,8 & 1,4 & 1,9 & 0,17 & 0,24 & 7 & 5 & 0 & 7 & 62 & 81 & 69 & 85 \\
\hline 243 & $\begin{array}{l}\text { Yerba Mala } \\
\text { \# } 251\end{array}$ & C. baccatum & 0 & - & 0,9 & - & 2,1 & - & 0,26 & - & 5 & - & 0 & - & 85 & - & 100 & - \\
\hline 337 & Pimenta & C. baccatum & 0,1 & - & 0,5 & - & 1,4 & - & 0,17 & - & 6 & - & 23 & - & 46 & - & 85 & - \\
\hline 340 & ICA \# 60 & C. baccatum & 0 & - & 0,4 & - & 1,2 & - & 0,15 & - & 6 & - & 0 & - & 54 & - & 69 & - \\
\hline 342 & Aji 284 & C. baccatum & 0,2 & - & 1,1 & - & 2,1 & - & 0,23 & - & 6 & - & 62 & - & 85 & - & 92 & - \\
\hline \multicolumn{19}{|c|}{ Suscetível } \\
\hline 120 & $\begin{array}{l}\text { Murupi IH } 1492 \\
\text { INPA }\end{array}$ & C. baccatum & 0,5 & - & 1,8 & - & 2,7 & - & 0,28 & - & 5 & - & 100 & - & 100 & - & 100 & - \\
\hline 203 & Aji \# 286 & C. baccatum & 0,5 & - & 1,8 & - & 2,7 & - & 0,28 & - & 5 & - & 92 & - & 100 & - & 100 & - \\
\hline 208 & $\begin{array}{l}\text { Aji Amarillo } \\
\text { \# } 67\end{array}$ & C. baccatum & 0,2 & - & 1,5 & - & 2,5 & - & 0,29 & - & 5 & - & 46 & - & 100 & - & 100 & - \\
\hline 213 & Arivivi \# 212 & C. baccatum & 0,3 & - & 1,3 & - & 2,6 & - & 0,29 & - & 5 & - & 69 & - & 92 & - & 100 & - \\
\hline 218 & BGH 1037 & C. baccatum & 0,2 & - & 1,5 & - & 2,7 & - & 0,32 & - & 5 & - & 39 & - & 92 & - & 100 & - \\
\hline 221 & BGH 2994 & C. baccatum & 0,1 & - & 1,7 & - & 2,5 & - & 0,3 & - & 5 & - & 62 & - & 100 & - & 100 & - \\
\hline 223 & BGH 4301 & C. baccatum & 0,2 & - & 1,2 & - & 2,6 & - & 0,29 & - & 5 & - & 69 & - & 85 & - & 100 & - \\
\hline 229 & $\begin{array}{l}\text { Habanera BG } \\
592\end{array}$ & C. baccatum & 0,2 & - & 1,3 & - & 2,8 & - & 0,32 & - & 4 & - & 39 & - & 92 & - & 100 & - \\
\hline 232 & ICA \# 65 & C. baccatum & 0,5 & 0,2 & 2,2 & 1,7 & 3,5 & 2,7 & 0,37 & 0,32 & 5 & 3 & 77 & 33 & 100 & 100 & 100 & 100 \\
\hline 236 & Pimenta & C. baccatum & 0,2 & - & 1,2 & - & 2,4 & - & 0,28 & - & 6 & - & 31 & - & 92 & - & 100 & - \\
\hline 240 & Pimenta Coração & C. baccatum & 0,6 & - & 2 & - & 3 & - & 0,31 & - & 4 & - & 77 & - & 100 & - & 100 & - \\
\hline \multicolumn{19}{|c|}{ Resistente } \\
\hline 105 & Bode & C. chinense & 0,1 & - & 0,7 & - & 1,6 & - & 0,19 & - & 5 & - & 23 & - & 69 & - & 92 & - \\
\hline 141 & Pimenta n² & C. chinense & 0,1 & - & 0,8 & - & 1,5 & - & 0,18 & - & 5 & - & 15 & - & 54 & - & 54 & - \\
\hline \multicolumn{19}{|c|}{ Intermediário } \\
\hline 110 & Habanera & C. chinense & 0,2 & - & 1,2 & - & 2,2 & - & 0,25 & - & 5 & - & 62 & - & 92 & - & 92 & - \\
\hline
\end{tabular}


Tabela 4 Reação de acessos de Capsicum annuum, C. baccatum, C. chinense e C. frutescens quanto à ocorrência de antracnose em frutos, de acordo com o diâmetro de lesões e incidência aos 3, 7 e 11 dias após a inoculação (DAI), velocidade de crescimento de lesão, período latente e classificação dos acessos, pelo Teste Cluster para agrupamento em classes de resistência, nos dois experimentos de inoculação

\begin{tabular}{|c|c|c|c|c|c|c|c|c|c|c|c|c|c|c|c|c|c|c|}
\hline \multirow{3}{*}{$\mathbf{N}^{\circ}$} & \multirow{3}{*}{ Acesso } & \multirow{3}{*}{ Espécie } & \multicolumn{6}{|c|}{ Diâmetro de lesão (cm) } & \multirow{2}{*}{\multicolumn{2}{|c|}{$\begin{array}{l}\text { Vel. Cresc. } \\
\text { (cm/dia) }{ }^{1}\end{array}$}} & \multirow{2}{*}{\multicolumn{2}{|c|}{$\begin{array}{l}\text { Per. Latente } \\
\text { (DAI) }^{2}\end{array}$}} & \multicolumn{6}{|c|}{ Incidência (\%) } \\
\hline & & & \multicolumn{2}{|c|}{3 DAI } & \multicolumn{2}{|c|}{7 DAI } & \multicolumn{2}{|c|}{11 DAI } & & & & & \multicolumn{2}{|c|}{3 DAI } & \multicolumn{2}{|c|}{7 DAI } & \multicolumn{2}{|c|}{11 DAI } \\
\hline & & & $1^{\circ} \mathbf{E x}$ & $2^{\circ} \mathbf{E x}$ & $1^{\circ} \mathbf{E x}$ & $2^{\circ} \mathbf{E x}$ & $1^{\circ} \mathrm{Ex}$ & $2^{\circ} \mathrm{Ex}$ & \multicolumn{2}{|c|}{$\begin{array}{c}(\mathrm{cm} / \mathrm{dia})^{1} \\
1^{\circ} \mathrm{Ex} \quad 2^{\circ} \mathrm{Ex}\end{array}$} & $1^{\circ} \mathbf{E x}$ & $2^{\circ} \mathrm{Ex}$ & $1^{\circ} \mathbf{E x}$ & $2^{\circ} \mathbf{E x}$ & $1^{\circ} \mathrm{Ex}$ & $2^{\circ} \mathbf{E x}$ & $1^{\circ} \mathrm{Ex}$ & $2^{\circ} \mathrm{Ex}$ \\
\hline 125 & Pimenta chata & C. chinense & 0,2 & 0,1 & 1,2 & 0,8 & 2,1 & 1,6 & 0,24 & 0,2 & 5 & 3 & 69 & 17 & 92 & 50 & 92 & 94 \\
\hline 135 & $\begin{array}{l}\text { Pimenta doce } \\
\text { IH-1758 }\end{array}$ & C. chinense & 0,2 & & 1,1 & & 2 & & 0,23 & & 5 & & 77 & & 85 & & 85 & \\
\hline 145 & PI 152225 & C. chinense & 0 & - & 1,2 & - & 2,1 & - & 0,26 & - & 5 & - & 0 & - & 92 & - & 92 & - \\
\hline \multicolumn{19}{|c|}{ Suscetível } \\
\hline 112 & IAC \# 39 & C. chinense & 0,2 & - & 1,6 & - & 2,4 & - & 0,28 & - & 5 & - & 54 & - & 100 & - & 100 & - \\
\hline 119 & Murupi IH-1490 & C. chinense & 0,4 & - & 1,8 & - & 2,8 & - & 0,3 & - & 3 & - & 100 & - & 100 & - & 100 & - \\
\hline 122 & Pimenta & C. chinense & 0,6 & 0,2 & 1,6 & 1,3 & 2,5 & 2 & 0,23 & 0,23 & 5 & 3 & 92 & 44 & 92 & 83 & 92 & 94 \\
\hline 130 & Pimenta doce & C. chinense & 0,4 & - & 1,8 & - & 3 & - & 0,32 & - & 3 & - & 100 & - & 100 & - & 100 & - \\
\hline 131 & Pimenta doce & C. chinense & 0,1 & - & 1,8 & - & 2,9 & - & 0,35 & - & 5 & - & 39 & - & 100 & - & 100 & - \\
\hline 133 & $\begin{array}{l}\text { Pimenta doce } \\
\text { IH-1749 }\end{array}$ & C. chinense & 0,3 & - & 1,7 & - & 2,9 & - & 0,33 & - & 5 & - & 85 & - & 100 & - & 100 & - \\
\hline 134 & $\begin{array}{l}\text { Pimenta doce } \\
\text { IH-1750 }\end{array}$ & C. chinense & 0,1 & - & 1,5 & - & 2,8 & - & 0,34 & - & 5 & - & 39 & - & 92 & - & 92 & - \\
\hline 136 & $\begin{array}{l}\text { Pimenta doce } \\
\text { IH-1761 }\end{array}$ & C. chinense & 0,1 & - & 1,7 & - & 2,7 & - & 0,32 & - & 5 & - & 54 & - & 100 & - & 100 & - \\
\hline 142 & Pimenta ${ }^{\circ} 5$ & C. chinense & 0,3 & - & 1,6 & - & 2,7 & - & 0,3 & - & 5 & - & 77 & - & 92 & - & 92 & - \\
\hline 143 & Rabo de Масасо & C. chinense & 0,3 & - & 1,9 & - & 3,2 & - & 0,36 & - & 5 & - & 77 & - & 100 & - & 100 & - \\
\hline \multicolumn{19}{|c|}{ Suscetível } \\
\hline 402 & Jobito Picante & C. frutescens & 0,1 & 0,2 & 1,3 & 1,6 & 1,8 & 1,9 & 0,22 & 0,29 & 5 & 5 & 20 & 75 & 80 & 100 & 90 & 100 \\
\hline
\end{tabular}


Tabela 6 Reação de progênies de Capsicum oriundos de retrocuzamentos entre as espécies (C. annuum x C. chinense) x C. annuum, numerados de 1 a 19, representando a geração F3RC1 e entre as espécies [(C. annuum x C. chinense) x C. annuum] x C. annuum, numerados de 20 a 40, representando a geração F2RC2. Avaliação com base no diâmetro de lesão e incidência aos 3, 7 e 11 dias após a inoculação, velocidade de crescimento de lesão e período latente

\begin{tabular}{|c|c|c|c|c|c|c|c|c|c|}
\hline \multirow[t]{2}{*}{ Progênie } & \multirow[t]{2}{*}{ Planta } & \multicolumn{3}{|c|}{ Diâmetro de lesão (cm) } & \multirow{2}{*}{$\begin{array}{l}\text { Velocidade crescimento } \\
\text { de lesão }(\mathrm{cm} / \mathrm{dia})\end{array}$} & \multirow{2}{*}{$\begin{array}{l}\text { Período Latente } \\
\text { (DAI) }\end{array}$} & \multicolumn{3}{|c|}{ Incidência (\%) } \\
\hline & & 3 DAI & 7 DAI & 11 DAI & & & 3 DAI & 7 DAI & 11 DAI \\
\hline \multirow[t]{8}{*}{1} & A & 0,7 & 2,8 & 4,5 & 0,48 & 3 & 100 & 100 & 100 \\
\hline & B & 0,5 & 2,1 & 3,5 & 0,38 & 5 & 100 & 100 & 100 \\
\hline & $\mathrm{C}$ & 0,3 & 1,4 & 2,7 & 0,30 & 5 & 33 & 100 & 100 \\
\hline & $\mathrm{D}$ & 0,8 & 3,1 & 4,4 & 0,46 & 5 & 100 & 100 & 100 \\
\hline & $\mathrm{E}$ & 0,8 & 1,4 & 2,4 & 0,20 & 5 & 50 & 100 & 100 \\
\hline & $\mathrm{F}$ & 0,3 & 1,8 & 3,2 & 0,36 & 5 & 100 & 100 & 100 \\
\hline & G & 0,0 & 0,8 & 1,8 & 0,23 & 7 & 0 & 100 & 100 \\
\hline & $\mathrm{H}$ & 0,2 & 1,0 & 2,4 & 0,27 & 5 & 100 & 50 & 100 \\
\hline \multirow[t]{6}{*}{2} & A & 0,7 & 2,3 & 3,6 & 0,36 & 5 & 100 & 67 & 100 \\
\hline & B & 0,2 & 1,7 & 3,3 & 0,39 & 5 & 50 & 100 & 100 \\
\hline & $\mathrm{C}$ & 0,7 & 2,4 & 3,3 & 0,33 & 5 & 100 & 100 & 100 \\
\hline & D & 0,2 & 1,2 & 2,3 & 0,26 & 5 & 38 & 63 & 88 \\
\hline & $\mathrm{E}$ & 0,4 & 2,1 & 3,6 & 0,39 & 5 & 100 & 100 & 100 \\
\hline & $\mathrm{F}$ & 0,5 & 2,1 & 3,1 & 0,33 & 5 & 100 & 100 & 100 \\
\hline \multirow[t]{8}{*}{3} & A & 0,0 & 1,7 & 2,8 & 0,35 & 5 & 0 & 100 & 100 \\
\hline & B & 0,0 & 1,2 & 2,3 & 0,29 & 7 & 0 & 100 & 100 \\
\hline & $\mathrm{C}$ & 0,0 & 2,1 & 3,4 & 0,42 & 5 & 0 & 100 & 100 \\
\hline & $\mathrm{D}$ & 0,0 & 0,7 & 1,7 & 0,21 & 9 & 0 & 50 & 100 \\
\hline & $\mathrm{F}$ & 0,0 & 0,9 & 1,9 & 0,23 & 5 & 0 & 50 & 100 \\
\hline & G & 0,0 & 0,0 & 0,0 & 0,00 & Sem lesão & 0 & 0 & 0 \\
\hline & I & 0,0 & 1,1 & 2,6 & 0,33 & 7 & 0 & 100 & 100 \\
\hline & $\mathrm{J}$ & 0,1 & 0,4 & 0,9 & 0,10 & 9 & 17 & 42 & 67 \\
\hline \multirow[t]{5}{*}{4} & A & 0,0 & 0,0 & 0,0 & 0,00 & Sem lesão & 0 & 0 & 0 \\
\hline & B & 0,0 & 0,0 & 0,0 & 0,00 & Sem lesão & 0 & 0 & 0 \\
\hline & $\mathrm{C}$ & 0,0 & 0,0 & 0,7 & 0,09 & 11 & 0 & 0 & 50 \\
\hline & $\mathrm{D}$ & 0,4 & 0,6 & 1,4 & 0,13 & 5 & 25 & 50 & 50 \\
\hline & $\mathrm{E}$ & 0,1 & 0,7 & 1,7 & 0,20 & 5 & 13 & 50 & 63 \\
\hline
\end{tabular}


Tabela 6 Reação de progênies de Capsicum oriundos de retrocuzamentos entre as espécies (C. annuum x C. chinense) x C. annuum, numerados de 1 a 19, representando a geração F3RC1 e entre as espécies [(C. annuum x C. chinense) x C. annuum] x C. annuum, numerados de 20 a 40, representando a geração F2RC2. Avaliação com base no diâmetro de lesão e incidência aos 3, 7 e 11 dias após a inoculação, velocidade de crescimento de lesão e período latente

\begin{tabular}{|c|c|c|c|c|c|c|c|c|c|}
\hline \multirow[t]{2}{*}{ Progênie } & \multirow[t]{2}{*}{ Planta } & \multicolumn{3}{|c|}{ Diâmetro de lesão (cm) } & \multirow{2}{*}{$\begin{array}{l}\text { Velocidade crescimento } \\
\text { de lesão (cm/dia) }\end{array}$} & \multirow{2}{*}{$\begin{array}{c}\text { Período Latente } \\
\text { (DAI) }\end{array}$} & \multicolumn{3}{|c|}{ Incidência (\%) } \\
\hline & & 3 DAI & 7 DAI & 11 DAI & & & 3 DAI & 7 DAI & 11 DAI \\
\hline \multirow[t]{3}{*}{4} & $\mathrm{~F}$ & 0,0 & 0,0 & 0,0 & 0,00 & Sem lesão & 0 & 0 & 0 \\
\hline & G & 0,0 & 0,0 & 0,8 & 0,10 & 11 & 0 & 0 & 100 \\
\hline & $\mathrm{H}$ & 0,0 & 0,0 & 0,0 & 0,00 & Sem lesão & 0 & 0 & 50 \\
\hline \multirow[t]{9}{*}{5} & A & 0,0 & 1,7 & 3,2 & 0,39 & 5 & 0 & 100 & 100 \\
\hline & B & 0,1 & 1,1 & 2,0 & 0,23 & 5 & 29 & 71 & 71 \\
\hline & $\mathrm{C}$ & 0,2 & 2,2 & 3,9 & 0,45 & 3 & 50 & 100 & 100 \\
\hline & $\mathrm{E}$ & 0,3 & 1,5 & 3,4 & 0,39 & 3 & 50 & 100 & 100 \\
\hline & $\mathrm{F}$ & 0,0 & 1,5 & 2,7 & 0,33 & 5 & 0 & 100 & 100 \\
\hline & G & 0,7 & 2,0 & 4,0 & 0,41 & 5 & 100 & 100 & 100 \\
\hline & $\mathrm{H}$ & 0,0 & 0,0 & 0,0 & 0,00 & Sem lesão & 0 & 0 & 0 \\
\hline & $\mathrm{I}$ & 0,3 & 2,3 & 3,9 & 0,45 & 5 & 100 & 100 & 100 \\
\hline & $\mathrm{J}$ & 0,4 & 2,3 & 3,9 & 0,43 & 5 & 100 & 100 & 100 \\
\hline \multirow[t]{5}{*}{6} & A & 0,0 & 2,0 & 3,4 & 0,43 & 5 & 0 & 100 & 100 \\
\hline & B & 0,0 & 0,0 & 0,0 & 0,00 & Sem lesão & 0 & 0 & 0 \\
\hline & $\mathrm{D}$ & 0,0 & 0,4 & 2,3 & 0,29 & Sem esporos & 0 & 50 & 100 \\
\hline & $\mathrm{E}$ & 0,2 & 1,8 & 3,2 & 0,37 & 7 & 50 & 100 & 100 \\
\hline & $\mathrm{F}$ & 0,0 & 0,0 & 0,0 & 0,00 & Sem lesão & 0 & 0 & 0 \\
\hline \multirow[t]{5}{*}{7} & A & 0,0 & 0,0 & 0,7 & 0,08 & Sem esporos & 0 & 0 & 100 \\
\hline & B & 0,1 & 0,9 & 1,6 & 0,18 & 7 & 50 & 75 & 75 \\
\hline & $\mathrm{E}$ & 0,0 & 0,8 & 1,0 & 0,13 & 5 & 0 & 50 & 50 \\
\hline & $\mathrm{F}$ & 0,2 & 1,4 & 2,2 & 0,25 & 5 & 100 & 100 & 100 \\
\hline & $\mathrm{G}$ & 0,0 & 1,5 & 2,6 & 0,33 & 7 & 0 & 100 & 100 \\
\hline \multirow[t]{5}{*}{8} & A & 0,0 & 1,8 & 3,6 & 0,45 & 5 & 0 & 100 & 100 \\
\hline & B & 0,0 & 0,0 & 0,0 & 0,00 & Sem lesão & 0 & 0 & 0 \\
\hline & $\mathrm{C}$ & 0,0 & 2,0 & 3,5 & 0,44 & 7 & 0 & 100 & 100 \\
\hline & $\mathrm{D}$ & 0,3 & 1,1 & 1,7 & 0,18 & 7 & 50 & 50 & 50 \\
\hline & $\mathrm{E}$ & 0,0 & 0,0 & 0,0 & 0,00 & Sem lesão & 0 & 0 & 0 \\
\hline
\end{tabular}


Tabela 6 Reação de progênies de Capsicum oriundos de retrocuzamentos entre as espécies (C. annuum x C. chinense) x C. annuum, numerados de 1 a 19, representando a geração F3RC1 e entre as espécies [(C. annuum x C. chinense) x C. annuum] x C. annuum, numerados de 20 a 40, representando a geração F2RC2. Avaliação com base no diâmetro de lesão e incidência aos 3, 7 e 11 dias após a inoculação, velocidade de crescimento de lesão e período latente

\begin{tabular}{|c|c|c|c|c|c|c|c|c|c|}
\hline \multirow[t]{2}{*}{ Progênie } & \multirow[t]{2}{*}{ Planta } & \multicolumn{3}{|c|}{ Diâmetro de lesão (cm) } & \multirow{2}{*}{$\begin{array}{l}\text { Velocidade crescimento } \\
\text { de lesão (cm/dia) }\end{array}$} & \multirow{2}{*}{$\begin{array}{c}\text { Período Latente } \\
\text { (DAI) }\end{array}$} & \multicolumn{3}{|c|}{ Incidência (\%) } \\
\hline & & 3 DAI & 7 DAI & 11 DAI & & & 3 DAI & 7 DAI & 11 DAI \\
\hline \multirow[t]{5}{*}{8} & $\mathrm{~F}$ & 0,0 & 0,0 & 0,0 & 0,00 & Sem lesão & 0 & 0 & 0 \\
\hline & $\mathrm{G}$ & 0,7 & 2,9 & 4,4 & 0,46 & 5 & 100 & 100 & 100 \\
\hline & $\mathrm{H}$ & 0,2 & 1,8 & 3,3 & 0,38 & 5 & 50 & 100 & 100 \\
\hline & $\mathrm{I}$ & 0,3 & 1,4 & 2,8 & 0,32 & 5 & 100 & 100 & 100 \\
\hline & $\mathrm{J}$ & 0,3 & 2,2 & 3,6 & 0,41 & 5 & 100 & 100 & 100 \\
\hline \multirow[t]{10}{*}{9} & A & 0,2 & 1,0 & 1,5 & 0,16 & 5 & 36 & 47 & 47 \\
\hline & B & 0,0 & 0,0 & 0,0 & 0,00 & Sem lesão & 0 & 0 & 0 \\
\hline & $\mathrm{C}$ & 0,1 & 1,7 & 2,8 & 0,33 & 5 & 33 & 78 & 78 \\
\hline & $\mathrm{D}$ & 0,0 & 0,0 & 0,0 & 0,00 & Sem lesão & 0 & 0 & 0 \\
\hline & $\mathrm{E}$ & 0,0 & 0,0 & 0,0 & 0,00 & Sem lesão & 0 & 0 & 0 \\
\hline & $\mathrm{F}$ & 0,0 & 0,0 & 1,1 & 0,14 & 7 & 0 & 0 & 50 \\
\hline & G & 0,0 & 1,0 & 2,1 & 0,26 & 5 & 0 & 100 & 100 \\
\hline & $\mathrm{H}$ & 0,1 & 0,3 & 1,0 & 0,11 & 5 & 25 & 25 & 50 \\
\hline & I & 0,1 & 1,6 & 2,8 & 0,34 & 5 & 50 & 100 & 100 \\
\hline & $\mathrm{J}$ & 0,0 & 0,0 & 0,0 & 0,00 & Sem lesão & 0 & 0 & 0 \\
\hline \multirow[t]{5}{*}{10} & A & 0,0 & 0,0 & 0,0 & 0,00 & Sem lesão & 0 & 0 & 0 \\
\hline & B & 0,0 & 1,8 & 2,8 & 0,34 & 5 & 0 & 100 & 100 \\
\hline & $\mathrm{C}$ & 0,0 & 0,7 & 1,5 & 0,18 & 7 & 9 & 55 & 55 \\
\hline & $\mathrm{D}$ & 0,5 & 2,0 & 3,1 & 0,33 & 5 & 100 & 100 & 100 \\
\hline & G & 0,0 & 2,1 & 3,8 & 0,47 & 5 & 0 & 100 & 100 \\
\hline \multirow[t]{7}{*}{11} & A & 0,0 & 3,3 & 4,5 & 0,56 & 5 & 0 & 100 & 100 \\
\hline & B & 0,5 & 2,8 & 4,8 & 0,53 & 5 & 100 & 100 & 100 \\
\hline & $\mathrm{D}$ & 0,3 & 1,4 & 3,4 & 0,39 & 5 & 50 & 100 & 100 \\
\hline & $\mathrm{E}$ & 0,5 & 1,0 & 1,5 & 0,13 & 5 & 100 & 100 & 100 \\
\hline & $\mathrm{F}$ & 0,3 & 1,9 & 3,9 & 0,45 & 5 & 100 & 100 & 100 \\
\hline & $\mathrm{G}$ & 0,2 & 1,9 & 3,9 & 0,46 & 5 & 100 & 100 & 100 \\
\hline & $\mathrm{H}$ & 0,5 & 2,4 & 4,2 & 0,46 & 5 & 100 & 100 & 100 \\
\hline
\end{tabular}


Tabela 6 Reação de progênies de Capsicum oriundos de retrocuzamentos entre as espécies (C. annuum x C. chinense) x C. annuum, numerados de 1 a 19, representando a geração F3RC1 e entre as espécies [(C. annuum x C. chinense) x C. annuum] x C. annuum, numerados de 20 a 40, representando a geração F2RC2. Avaliação com base no diâmetro de lesão e incidência aos 3, 7 e 11 dias após a inoculação, velocidade de crescimento de lesão e período latente

\begin{tabular}{|c|c|c|c|c|c|c|c|c|c|}
\hline \multirow[t]{2}{*}{ Progênie } & \multirow[t]{2}{*}{ Planta } & \multicolumn{3}{|c|}{ Diâmetro de lesão (cm) } & \multirow{2}{*}{$\begin{array}{l}\text { Velocidade crescimento } \\
\text { de lesão (cm/dia) }\end{array}$} & \multirow{2}{*}{$\begin{array}{c}\text { Período Latente } \\
\text { (DAI) }\end{array}$} & \multicolumn{3}{|c|}{ Incidência (\%) } \\
\hline & & 3 DAI & 7 DAI & 11 DAI & & & 3 DAI & 7 DAI & 11 DAI \\
\hline 11 & I & 0,4 & 2,5 & 4,5 & 0,51 & 5 & 100 & 100 & 100 \\
\hline \multirow[t]{8}{*}{12} & A & 0,0 & 1,0 & 2,8 & 0,34 & 5 & 0 & 100 & 100 \\
\hline & $\mathrm{B}$ & 0,5 & 2,3 & 3,8 & 0,42 & 5 & 100 & 100 & 100 \\
\hline & $\mathrm{C}$ & 0,5 & 2,5 & 4,2 & 0,47 & 5 & 100 & 100 & 100 \\
\hline & $\mathrm{D}$ & 0,0 & 0,6 & 2,4 & 0,30 & 7 & 0 & 50 & 100 \\
\hline & $\mathrm{E}$ & 0,0 & 1,2 & 3,0 & 0,37 & 7 & 0 & 100 & 100 \\
\hline & $\mathrm{F}$ & 0,5 & 2,2 & 3,9 & 0,43 & 5 & 100 & 100 & 100 \\
\hline & G & 0,2 & 1,4 & 2,1 & 0,25 & 7 & 25 & 75 & 50 \\
\hline & I & 0,0 & 1,8 & 3,4 & 0,43 & 5 & 0 & 100 & 100 \\
\hline \multirow[t]{7}{*}{13} & A & 0,0 & 0,8 & 2,7 & 0,34 & 9 & 0 & 50 & 100 \\
\hline & B & 0,5 & 2,1 & 3,8 & 0,41 & 3 & 100 & 100 & 100 \\
\hline & $\mathrm{C}$ & 0,3 & 2,0 & 3,7 & 0,42 & 5 & 100 & 100 & 100 \\
\hline & $\mathrm{D}$ & 0,0 & 0,0 & 0,0 & 0,00 & Sem lesão & 0 & 0 & 0 \\
\hline & $\mathrm{F}$ & 0,0 & 0,0 & 0,0 & 0,00 & Sem lesão & 0 & 0 & 0 \\
\hline & $\mathrm{H}$ & 0,0 & 0,7 & 2,1 & 0,26 & 7 & 0 & 40 & 80 \\
\hline & I & 0,0 & 1,5 & 3,1 & 0,39 & Sem esporos & 0 & 100 & 100 \\
\hline \multirow[t]{7}{*}{14} & $\mathrm{~A}$ & 0,0 & 0,0 & 0,0 & 0,00 & Sem lesão & 0 & 0 & 0 \\
\hline & B & 0,0 & 1,1 & 2,8 & 0,34 & 7 & 0 & 100 & 50 \\
\hline & $\mathrm{C}$ & 0,0 & 0,0 & 0,0 & 0,00 & Sem lesão & 0 & 0 & 0 \\
\hline & $\mathrm{D}$ & 0,4 & 2,4 & 4,0 & 0,46 & 3 & 75 & 100 & 100 \\
\hline & $\mathrm{F}$ & 0,1 & 1,5 & 2,9 & 0,36 & 5 & 33 & 100 & 100 \\
\hline & $\mathrm{G}$ & 0,3 & 1,1 & 2,4 & 0,27 & 5 & 50 & 50 & 100 \\
\hline & $\mathrm{H}$ & 0,2 & 1,4 & 2,9 & 0,34 & 5 & 67 & 100 & 100 \\
\hline \multirow[t]{4}{*}{15} & B & 0,5 & 2,4 & 3,8 & 0,41 & 5 & 100 & 100 & 100 \\
\hline & $\mathrm{C}$ & 0,2 & 1,9 & 3,3 & 0,39 & 5 & 67 & 100 & 100 \\
\hline & $\mathrm{F}$ & 0,8 & 2,7 & 4,4 & 0,46 & 3 & 100 & 100 & 100 \\
\hline & $\mathrm{G}$ & 0,0 & 1,3 & 3,1 & 0,39 & 5 & 0 & 100 & 100 \\
\hline
\end{tabular}


Tabela 6 Reação de progênies de Capsicum oriundos de retrocuzamentos entre as espécies (C. annuum x C. chinense) x C. annuum, numerados de 1 a 19, representando a geração F3RC1 e entre as espécies [(C. annuum x C. chinense) x C. annuum] x C. annuum, numerados de 20 a 40, representando a geração F2RC2. Avaliação com base no diâmetro de lesão e incidência aos 3, 7 e 11 dias após a inoculação, velocidade de crescimento de lesão e período latente

\begin{tabular}{|c|c|c|c|c|c|c|c|c|c|}
\hline \multirow[t]{2}{*}{ Progênie } & \multirow[t]{2}{*}{ Planta } & \multicolumn{3}{|c|}{ Diâmetro de lesão (cm) } & \multirow{2}{*}{$\begin{array}{l}\text { Velocidade crescimento } \\
\text { de lesão (cm/dia) }\end{array}$} & \multirow{2}{*}{$\begin{array}{l}\text { Período Latente } \\
\text { (DAI) }\end{array}$} & \multicolumn{3}{|c|}{ Incidência (\%) } \\
\hline & & 3 DAI & 7 DAI & 11 DAI & & & 3 DAI & 7 DAI & 11 DAI \\
\hline \multirow[t]{10}{*}{16} & A & 0,5 & 2,0 & 3,4 & 0,35 & 5 & 100 & 100 & 100 \\
\hline & $\mathrm{B}$ & 0,3 & 1,6 & 2,8 & 0,31 & 5 & 100 & 100 & 100 \\
\hline & $\mathrm{C}$ & 0,0 & 0,7 & 2,4 & 0,30 & 7 & 0 & 100 & 100 \\
\hline & $\mathrm{D}$ & 0,0 & 0,0 & $\overrightarrow{0,0}$ & 0,00 & Sem lesão & 0 & 0 & 0 \\
\hline & $\mathrm{E}$ & 0,1 & 2,0 & 3,2 & 0,38 & 5 & 33 & 100 & 100 \\
\hline & $\mathrm{F}$ & 0,0 & 0,0 & 1,6 & 0,20 & 11 & 0 & 0 & 100 \\
\hline & $\mathrm{G}$ & 0,3 & 1,4 & 2,1 & 0,24 & 5 & 50 & 50 & 75 \\
\hline & $\mathrm{H}$ & 0,6 & 2,6 & 4,3 & 0,46 & 5 & 100 & 100 & 100 \\
\hline & I & 0,0 & 0,0 & 0,0 & 0,00 & Sem lesão & 0 & 0 & 0 \\
\hline & $\mathrm{J}$ & 0,2 & 1,4 & 3,6 & 0,42 & 5 & 67 & 0 & 100 \\
\hline \multirow{5}{*}{17} & A & 0,0 & 1,6 & 2,9 & 0,36 & 5 & 0 & 100 & 100 \\
\hline & B & 0,0 & 0,0 & 0,0 & 0,00 & Sem lesão & 0 & 0 & 0 \\
\hline & $\mathrm{C}$ & 0,2 & 1,6 & 2,9 & 0,34 & 5 & 50 & 100 & 100 \\
\hline & $\mathrm{D}$ & 0,2 & 1,1 & 1,8 & 0,20 & 5 & 50 & 50 & 50 \\
\hline & $\mathrm{E}$ & 0,0 & 1,2 & 2,8 & 0,34 & 5 & 0 & 100 & 100 \\
\hline \multirow[t]{10}{*}{18} & $\mathrm{~A}$ & 0,6 & 2,2 & 3,7 & 0,39 & 3 & 100 & 100 & 100 \\
\hline & B & 0,3 & 1,8 & 3,3 & 0,38 & 3 & 50 & 100 & 100 \\
\hline & $\mathrm{C}$ & 0,0 & 0,0 & 0,9 & 0,11 & 11 & 0 & 0 & 100 \\
\hline & $\mathrm{D}$ & 0,1 & 1,9 & 3,6 & 0,44 & 5 & 0 & 100 & 100 \\
\hline & $\mathrm{E}$ & 0,0 & 1,1 & 2,8 & 0,35 & 7 & 0 & 100 & 100 \\
\hline & $\mathrm{F}$ & 1,5 & 2,3 & 3,3 & 0,22 & 5 & 100 & 100 & 100 \\
\hline & G & 0,3 & 2,5 & 4,1 & 0,48 & 5 & 100 & 100 & 100 \\
\hline & $\mathrm{H}$ & 0,1 & 1,7 & 3,4 & 0,41 & 5 & 50 & 50 & 100 \\
\hline & I & 0,0 & 1,1 & 3,3 & 0,41 & 7 & 0 & 100 & 100 \\
\hline & $\mathrm{J}$ & 0,0 & 1,2 & 2,9 & 0,37 & 5 & 0 & 100 & 100 \\
\hline \multirow[t]{2}{*}{19} & A & 0,2 & 1,8 & 3,1 & 0,36 & 5 & 50 & 100 & 100 \\
\hline & B & 0,0 & 0,0 & 0,0 & 0,00 & Sem lesão & 0 & 0 & 0 \\
\hline
\end{tabular}


Tabela 6 Reação de progênies de Capsicum oriundos de retrocuzamentos entre as espécies (C. annuum x C. chinense) x C. annuum, numerados de 1 a 19, representando a geração F3RC1 e entre as espécies [(C. annuum x C. chinense) x C. annuum] x C. annuum, numerados de 20 a 40, representando a geração F2RC2. Avaliação com base no diâmetro de lesão e incidência aos 3, 7 e 11 dias após a inoculação, velocidade de crescimento de lesão e período latente

\begin{tabular}{|c|c|c|c|c|c|c|c|c|c|}
\hline \multirow[t]{2}{*}{ Progênie } & \multirow[t]{2}{*}{ Planta } & \multicolumn{3}{|c|}{ Diâmetro de lesão (cm) } & \multirow{2}{*}{$\begin{array}{l}\text { Velocidade crescimento } \\
\text { de lesão }(\mathrm{cm} / \mathrm{dia})\end{array}$} & \multirow{2}{*}{$\begin{array}{l}\text { Período Latente } \\
\text { (DAI) }\end{array}$} & \multicolumn{3}{|c|}{ Incidência (\%) } \\
\hline & & 3 DAI & 7 DAI & 11 DAI & & & 3 DAI & 7 DAI & 11 DAI \\
\hline \multirow[t]{4}{*}{19} & $\mathrm{C}$ & 0,0 & 1,4 & 3,2 & 0,40 & 5 & 0 & 100 & 100 \\
\hline & $\mathrm{E}$ & 0,4 & 1,8 & 3,0 & 0,33 & 5 & 100 & 100 & 100 \\
\hline & $\mathrm{F}$ & 0,4 & 1,5 & 2,4 & 0,25 & 3 & 57 & 86 & 86 \\
\hline & $\mathrm{G}$ & 0,6 & 2,3 & 3,2 & 0,32 & 3 & 75 & 100 & 100 \\
\hline \multirow[t]{5}{*}{20} & A & 0,2 & 1,7 & 3,2 & 0,37 & 5 & 75 & 100 & 100 \\
\hline & B & 0,1 & 1,2 & 2,7 & 0,34 & 5 & 33 & 67 & 100 \\
\hline & $\mathrm{D}$ & 0,3 & 1,5 & 3,1 & 0,35 & 5 & 100 & 100 & 100 \\
\hline & $\mathrm{E}$ & 0,0 & 1,0 & 2,9 & 0,36 & 5 & 0 & 67 & 100 \\
\hline & G & 0,0 & 1,4 & 2,6 & 0,33 & 5 & 0 & 100 & 100 \\
\hline \multirow[t]{8}{*}{21} & A & 0,4 & 2,1 & 3,4 & 0,37 & 3 & 50 & 100 & 100 \\
\hline & B & 0,3 & 2,3 & 3,8 & 0,43 & 3 & 75 & 100 & 100 \\
\hline & $\mathrm{C}$ & 0,2 & 1,7 & 2,9 & 0,33 & 5 & 29 & 71 & 71 \\
\hline & $\mathrm{D}$ & 0,3 & 2,2 & 3,7 & 0,43 & 5 & 67 & 100 & 100 \\
\hline & $\mathrm{E}$ & 0,7 & 2,3 & 3,7 & 0,38 & 3 & 100 & 100 & 100 \\
\hline & $\mathrm{F}$ & 0,3 & 0,9 & 1,6 & 0,16 & 3 & 50 & 50 & 75 \\
\hline & $\mathrm{H}$ & 0,6 & 1,9 & 3,0 & 0,30 & 3 & 100 & 100 & 100 \\
\hline & I & 0,0 & 1,7 & 3,2 & 0,39 & 5 & 0 & 100 & 100 \\
\hline \multirow[t]{8}{*}{22} & A & 0,6 & 2,3 & 3,8 & 0,40 & 3 & 100 & 100 & 100 \\
\hline & A & 0,3 & 1,6 & 3,0 & 0,33 & 5 & 100 & 100 & 100 \\
\hline & B & 0,6 & 2,4 & 3,9 & 0,41 & 3 & 50 & 100 & 100 \\
\hline & $\mathrm{C}$ & 0,2 & 1,8 & 2,9 & 0,34 & 5 & 100 & 100 & 100 \\
\hline & D & 0,5 & 2,0 & 3,0 & 0,32 & 5 & 60 & 100 & 100 \\
\hline & $\mathrm{E}$ & 0,0 & 1,8 & 3,3 & 0,41 & 3 & 0 & 100 & 100 \\
\hline & $\mathrm{F}$ & 0,0 & 1,1 & 2,8 & 0,35 & 7 & 0 & 100 & 100 \\
\hline & I & 0,0 & 1,5 & 3,0 & 0,37 & 3 & 0 & 100 & 100 \\
\hline \multirow[t]{2}{*}{24} & A & 0,9 & 2,5 & 3,8 & 0,37 & 3 & 100 & 100 & 100 \\
\hline & B & 0,0 & 1,6 & 3,0 & 0,38 & 5 & 0 & 100 & 100 \\
\hline
\end{tabular}


Tabela 6 Reação de progênies de Capsicum oriundos de retrocuzamentos entre as espécies (C. annuum x C. chinense) x C. annuum, numerados de 1 a 19, representando a geração F3RC1 e entre as espécies [(C. annuum x C. chinense) x C. annuum] x C. annuum, numerados de 20 a 40, representando a geração F2RC2. Avaliação com base no diâmetro de lesão e incidência aos 3, 7 e 11 dias após a inoculação, velocidade de crescimento de lesão e período latente

\begin{tabular}{|c|c|c|c|c|c|c|c|c|c|}
\hline \multirow[t]{2}{*}{ Progênie } & \multirow[t]{2}{*}{ Planta } & \multicolumn{3}{|c|}{ Diâmetro de lesão (cm) } & \multirow{2}{*}{$\begin{array}{l}\text { Velocidade crescimento } \\
\text { de lesão }(\mathrm{cm} / \mathrm{dia})\end{array}$} & \multirow{2}{*}{$\begin{array}{l}\text { Período Latente } \\
\text { (DAI) }\end{array}$} & \multicolumn{3}{|c|}{ Incidência (\%) } \\
\hline & & 3 DAI & 7 DAI & 11 DAI & & & 3 DAI & 7 DAI & 11 DAI \\
\hline \multirow[t]{5}{*}{24} & $\mathrm{C}$ & 0,8 & 2,4 & 4,0 & 0,40 & 3 & 100 & 100 & 100 \\
\hline & $\mathrm{D}$ & 0,7 & 2,2 & 3,5 & 0,35 & 3 & 100 & 100 & 100 \\
\hline & $\mathrm{F}$ & 0,7 & 2,7 & 4,7 & 0,50 & 5 & 100 & 100 & 100 \\
\hline & G & 0,9 & 2,7 & 4,1 & 0,39 & 3 & 100 & 100 & 100 \\
\hline & $\mathrm{H}$ & 0,3 & 2,1 & 3,8 & 0,44 & 5 & 100 & 100 & 100 \\
\hline 25 & A & 0,7 & 2,5 & 4,1 & 0,43 & 5 & 100 & 100 & 100 \\
\hline \multirow[t]{3}{*}{26} & A & 0,2 & 1,0 & 2,7 & 0,31 & 3 & 33 & 50 & 100 \\
\hline & B & 0,3 & 1,9 & 3,6 & 0,40 & 5 & 50 & 83 & 100 \\
\hline & $\mathrm{C}$ & 0,5 & 2,3 & 3,3 & 0,34 & 5 & 50 & 100 & 100 \\
\hline \multirow[t]{8}{*}{27} & A & 0,0 & 2,0 & 3,8 & 0,48 & 5 & 0 & 100 & 100 \\
\hline & B & 0,4 & 1,7 & 3,5 & 0,39 & 5 & 50 & 100 & 100 \\
\hline & $\mathrm{C}$ & 0,7 & 2,2 & 3,2 & 0,31 & 3 & 100 & 100 & 100 \\
\hline & D & 0,0 & 2,6 & 3,3 & 0,41 & 5 & 0 & 100 & 100 \\
\hline & $\mathrm{E}$ & 0,0 & 4,2 & 5,8 & 0,72 & 7 & 0 & 100 & 100 \\
\hline & $\mathrm{F}$ & 0,4 & 2,3 & 3,9 & 0,44 & 3 & 50 & 100 & 100 \\
\hline & G & 0,3 & 2,0 & 3,6 & 0,41 & 5 & 100 & 100 & 100 \\
\hline & $\mathrm{H}$ & 0,5 & 2,0 & 4,0 & 0,44 & 3 & 100 & 100 & 100 \\
\hline \multirow[t]{5}{*}{28} & A & 0,0 & 1,6 & 3,5 & 0,44 & 7 & 0 & 100 & 100 \\
\hline & B & 0,5 & 1,5 & 2,6 & 0,26 & 5 & 100 & 100 & 100 \\
\hline & C & 0,0 & 1,7 & 3,3 & 0,41 & 5 & 0 & 100 & 100 \\
\hline & D & 0,2 & 1,8 & 3,1 & 0,37 & 5 & 100 & 100 & 100 \\
\hline & $\mathrm{E}$ & 0,4 & 2,0 & 3,1 & 0,34 & 5 & 50 & 100 & 100 \\
\hline \multirow[t]{3}{*}{29} & A & 0,5 & 2,4 & 4,1 & 0,46 & 5 & 100 & 100 & 100 \\
\hline & B & 0,4 & 2,2 & 3,8 & 0,41 & 5 & 100 & 100 & 100 \\
\hline & $\mathrm{E}$ & 0,0 & 1,7 & 3,8 & 0,48 & 5 & 0 & 100 & 100 \\
\hline \multirow[t]{2}{*}{30} & A & 0,0 & 1,5 & 3,0 & 0,38 & 7 & 0 & 100 & 100 \\
\hline & B & 0,0 & 2,3 & 4,2 & 0,52 & 5 & 0 & 100 & 100 \\
\hline
\end{tabular}


Tabela 6 Reação de progênies de Capsicum oriundos de retrocuzamentos entre as espécies (C. annuum x C. chinense) x C. annuum, numerados de 1 a 19, representando a geração F3RC1 e entre as espécies [(C. annuum x C. chinense) x C. annuum] x C. annuum, numerados de 20 a 40, representando a geração F2RC2. Avaliação com base no diâmetro de lesão e incidência aos 3, 7 e 11 dias após a inoculação, velocidade de crescimento de lesão e período latente

\begin{tabular}{|c|c|c|c|c|c|c|c|c|c|}
\hline \multirow[t]{2}{*}{ Progênie } & \multirow[t]{2}{*}{ Planta } & \multicolumn{3}{|c|}{ Diâmetro de lesão (cm) } & \multirow{2}{*}{$\begin{array}{l}\text { Velocidade crescimento } \\
\text { de lesão }(\mathrm{cm} / \mathrm{dia})\end{array}$} & \multirow{2}{*}{$\begin{array}{l}\text { Período Latente } \\
\text { (DAI) }\end{array}$} & \multicolumn{3}{|c|}{ Incidência (\%) } \\
\hline & & 3 DAI & 7 DAI & 11 DAI & & & 3 DAI & 7 DAI & 11 DAI \\
\hline \multirow[t]{4}{*}{30} & $\mathrm{C}$ & 0,5 & 2,0 & 3,4 & 0,36 & 5 & 100 & 100 & 100 \\
\hline & $\mathrm{D}$ & 0,7 & 2,4 & 3,9 & 0,40 & 3 & 100 & 100 & 100 \\
\hline & $\mathrm{E}$ & 0,5 & 2,3 & 4,0 & 0,44 & 5 & 100 & 100 & 100 \\
\hline & $\mathrm{F}$ & 0,5 & 1,9 & 3,3 & 0,36 & 5 & 100 & 100 & 100 \\
\hline \multirow[t]{8}{*}{31} & A & 0,0 & 1,7 & 3,4 & 0,43 & 5 & 0 & 100 & 100 \\
\hline & $\mathrm{B}$ & 0,6 & 2,5 & 3,3 & 0,34 & 5 & 100 & 100 & 100 \\
\hline & $\mathrm{C}$ & 0,0 & 0,6 & 1,2 & 0,15 & 5 & 0 & 50 & 50 \\
\hline & $\mathrm{D}$ & 0,7 & 2,6 & 4,4 & 0,47 & 5 & 100 & 100 & 100 \\
\hline & E & 0,0 & 1,8 & 3,4 & 0,43 & 5 & 0 & 100 & 100 \\
\hline & $\mathrm{F}$ & 0,5 & 2,6 & 4,4 & 0,49 & 5 & 100 & 100 & 100 \\
\hline & G & 0,0 & 2,0 & 3,5 & 0,44 & 5 & 0 & 100 & 100 \\
\hline & $\mathrm{H}$ & 0,0 & 2,2 & 3,0 & 0,38 & 5 & 0 & 100 & 100 \\
\hline \multirow[t]{3}{*}{32} & A & 0,5 & 2,3 & 3,8 & 0,42 & 5 & 67 & 100 & 100 \\
\hline & B & 0,0 & 1,5 & 3,1 & 0,39 & 5 & 0 & 67 & 100 \\
\hline & $\mathrm{C}$ & 0,0 & 2,0 & 3,4 & 0,43 & 5 & 0 & 100 & 100 \\
\hline \multirow[t]{5}{*}{33} & $\mathrm{D}$ & 0,7 & 2,5 & 4,0 & 0,41 & 3 & 100 & 100 & 100 \\
\hline & $\mathrm{F}$ & 0,0 & 0,0 & 0,0 & 0,00 & Sem lesão & 0 & 0 & 0 \\
\hline & G & 0,0 & 2,0 & 3,9 & 0,48 & 5 & 0 & 100 & 100 \\
\hline & $\mathrm{H}$ & 0,2 & 2,0 & 3,3 & 0,39 & 3 & 67 & 100 & 100 \\
\hline & I & 0,0 & 2,1 & 3,9 & 0,48 & 5 & 0 & 100 & 100 \\
\hline \multirow[t]{7}{*}{34} & A & 0,2 & 2,0 & 3,0 & 0,35 & 5 & 67 & 100 & 100 \\
\hline & B & 0,6 & 2,2 & 3,4 & 0,35 & 5 & 100 & 100 & 100 \\
\hline & $\mathrm{D}$ & 0,3 & 1,9 & 3,2 & 0,36 & 5 & 50 & 100 & 100 \\
\hline & $\mathrm{E}$ & 0,4 & 1,2 & 2,1 & 0,21 & 3 & 57 & 71 & 71 \\
\hline & $\mathrm{F}$ & 0,2 & 0,8 & 2,6 & 0,30 & 9 & 33 & 100 & 100 \\
\hline & G & 1,1 & 2,2 & 3,4 & 0,29 & 3 & 100 & 100 & 100 \\
\hline & I & 0,2 & 0,9 & 1,4 & 0,15 & 5 & 67 & 67 & 67 \\
\hline
\end{tabular}


Tabela 6 Reação de progênies de Capsicum oriundos de retrocuzamentos entre as espécies (C. annuum x C. chinense) x C. annuum, numerados de 1 a 19, representando a geração F3RC1 e entre as espécies [(C. annuum x C. chinense) x C. annuum] x C. annuum, numerados de 20 a 40, representando a geração F2RC2. Avaliação com base no diâmetro de lesão e incidência aos 3, 7 e 11 dias após a inoculação, velocidade de crescimento de lesão e período latente

\begin{tabular}{|c|c|c|c|c|c|c|c|c|c|}
\hline \multirow[t]{2}{*}{ Progênie } & \multirow[t]{2}{*}{ Planta } & \multicolumn{3}{|c|}{ Diâmetro de lesão (cm) } & \multirow{2}{*}{$\begin{array}{l}\text { Velocidade crescimento } \\
\text { de lesão }(\mathrm{cm} / \mathrm{dia})\end{array}$} & \multirow{2}{*}{$\begin{array}{c}\text { Período Latente } \\
\text { (DAI) }\end{array}$} & \multicolumn{3}{|c|}{ Incidência (\%) } \\
\hline & & 3 DAI & 7 DAI & 11 DAI & & & 3 DAI & 7 DAI & 11 DAI \\
\hline 34 & $\mathrm{~J}$ & 0,4 & 1,5 & 2,2 & 0,22 & 5 & 70 & 80 & 80 \\
\hline \multirow[t]{7}{*}{35} & A & 0,0 & 2,0 & 3,7 & 0,46 & 5 & 0 & 100 & 100 \\
\hline & $\mathrm{B}$ & 0,0 & 1,5 & 3,0 & 0,38 & 5 & 0 & 100 & 100 \\
\hline & $\mathrm{D}$ & 0,4 & 2,2 & 3,6 & 0,40 & 5 & 67 & 100 & 100 \\
\hline & $\mathrm{E}$ & 0,3 & 2,3 & 3,9 & 0,45 & 5 & 100 & 100 & 100 \\
\hline & $\mathrm{F}$ & 0,0 & 1,9 & 3,3 & 0,41 & 5 & 0 & 100 & 100 \\
\hline & $\mathrm{G}$ & 0,2 & 2,0 & 3,6 & 0,43 & 5 & 50 & 100 & 100 \\
\hline & $\mathrm{H}$ & 0,0 & 1,6 & 3,3 & 0,41 & 5 & 0 & 100 & 100 \\
\hline \multirow[t]{3}{*}{36} & A & 0,7 & 2,4 & 4,4 & 0,47 & 5 & 100 & 100 & 100 \\
\hline & B & 0,0 & 1,8 & 3,9 & 0,49 & 5 & 0 & 100 & 100 \\
\hline & $\mathrm{D}$ & 0,5 & 2,5 & 4,0 & 0,43 & 3 & 67 & 100 & 100 \\
\hline \multirow[t]{8}{*}{37} & A & 0,0 & 0,5 & 2,3 & 0,28 & 9 & 0 & 100 & 100 \\
\hline & B & 0,5 & 2,1 & 3,6 & 0,39 & 5 & 100 & 100 & 100 \\
\hline & C & 0,5 & 2,3 & 4,1 & 0,45 & 5 & 100 & 100 & 100 \\
\hline & $\mathrm{D}$ & 0,7 & 2,3 & 3,7 & 0,37 & 5 & 100 & 100 & 100 \\
\hline & $\mathrm{E}$ & 0,5 & 2,3 & 3,8 & 0,42 & 3 & 100 & 100 & 100 \\
\hline & $\mathrm{F}$ & 0,5 & 1,9 & 3,3 & 0,34 & 5 & 100 & 100 & 100 \\
\hline & $\mathrm{G}$ & 0,9 & 2,6 & 4,0 & 0,39 & 5 & 100 & 100 & 100 \\
\hline & $\mathrm{H}$ & 1,8 & 2,9 & 3,6 & 0,23 & 5 & 100 & 100 & 100 \\
\hline \multirow[t]{8}{*}{38} & A & 0,2 & 1,8 & 3,3 & 0,39 & 5 & 100 & 100 & 100 \\
\hline & B & 0,0 & 1,1 & 2,5 & 0,31 & 7 & 0 & 100 & 100 \\
\hline & $\mathrm{C}$ & 0,0 & 2,3 & 3,8 & 0,47 & 5 & 0 & 100 & 100 \\
\hline & $\mathrm{D}$ & 0,5 & 2,4 & 3,9 & 0,42 & 5 & 100 & 100 & 100 \\
\hline & $\mathrm{E}$ & 0,6 & 2,4 & 3,9 & 0,42 & 5 & 100 & 100 & 100 \\
\hline & $\mathrm{F}$ & 0,0 & 1,6 & 3,3 & 0,41 & 5 & 0 & 100 & 100 \\
\hline & $\mathrm{G}$ & 0,4 & 2,5 & 4,4 & 0,50 & 5 & 100 & 100 & 100 \\
\hline & $\mathrm{H}$ & 0,3 & 2,7 & 4,1 & 0,48 & 5 & 50 & 100 & 100 \\
\hline
\end{tabular}


Tabela 6 Reação de progênies de Capsicum oriundos de retrocuzamentos entre as espécies (C. annuum x C. chinense) x $C$. annuum, numerados de 1 a 19, representando a geração F3RC1 e entre as espécies [(C. annuum x C. chinense) x C. annuum] x C. annuum, numerados de 20 a 40, representando a geração F2RC2. Avaliação com base no diâmetro de lesão e incidência aos 3, 7 e 11 dias após a inoculação, velocidade de crescimento de lesão e período latente

\begin{tabular}{|c|c|c|c|c|c|c|c|c|c|}
\hline \multirow[t]{2}{*}{ Progênie } & \multirow[t]{2}{*}{ Planta } & \multicolumn{3}{|c|}{ Diâmetro de lesão (cm) } & \multirow{2}{*}{$\begin{array}{l}\text { Velocidade crescimento } \\
\text { de lesão }(\mathrm{cm} / \mathrm{dia})\end{array}$} & \multirow{2}{*}{$\begin{array}{l}\text { Período Latente } \\
\text { (DAI) }\end{array}$} & \multicolumn{3}{|c|}{ Incidência (\%) } \\
\hline & & 3 DAI & 7 DAI & 11 DAI & & & 3 DAI & 7 DAI & 11 DAI \\
\hline \multirow[t]{11}{*}{39} & A & 0,0 & 0,8 & 1,7 & 0,21 & 5 & 0 & 50 & 100 \\
\hline & $\mathrm{B}$ & 0,4 & 1,4 & 2,1 & 0,21 & 5 & 71 & 75 & 88 \\
\hline & $\mathrm{C}$ & 0,1 & 0,3 & 1,4 & 0,15 & 7 & 25 & 25 & 100 \\
\hline & $\mathrm{D}$ & 0,0 & 0,3 & 1,4 & 0,17 & 5 & 0 & 25 & 100 \\
\hline & $\mathrm{E}$ & 0,1 & 0,8 & 2,1 & 0,25 & 5 & 25 & 75 & 100 \\
\hline & $\mathrm{F}$ & 0,1 & 0,8 & 1,6 & 0,19 & 5 & 25 & 75 & 75 \\
\hline & G & 0,0 & 0,8 & 1,7 & 0,21 & 5 & 79 & 71 & 79 \\
\hline & $\mathrm{H}$ & 0,1 & 1,0 & 1,9 & 0,22 & 5 & 27 & 70 & 82 \\
\hline & I & 0,0 & 0,7 & 1,5 & 0,19 & 7 & 0 & 45 & 82 \\
\hline & $\mathrm{J}$ & 0,1 & 0,5 & 1,6 & 0,19 & 7 & 33 & 67 & 100 \\
\hline & $\mathrm{K}$ & 0,0 & 1,2 & 2,4 & 0,30 & 5 & 0 & 100 & 100 \\
\hline \multirow[t]{6}{*}{40} & A & 0,2 & 1,7 & 2,5 & 0,29 & 5 & 50 & 100 & 100 \\
\hline & B & 0,4 & 2,1 & 2,9 & 0,31 & 5 & 100 & 100 & 100 \\
\hline & $\mathrm{C}$ & 0,1 & 1,8 & 2,4 & 0,28 & 5 & 50 & 100 & 100 \\
\hline & $\mathrm{D}$ & 0,0 & 0,9 & 2,1 & 0,26 & 5 & 0 & 50 & 100 \\
\hline & $\mathrm{F}$ & 0,6 & 2,1 & 2,8 & 0,28 & 3 & 100 & 100 & 100 \\
\hline & G & 0,0 & 0,0 & 0,0 & 0,00 & Sem lesão & 0 & 0 & 0 \\
\hline
\end{tabular}


Tabela 7 Análise de correlação entre o diâmetro de lesões aos 3, 7 e 11 dias após a inoculação e velocidade de crescimento de lesões nos frutos e a severidade nas plântulas aos 3, 10 e 19 DAI e teste F. Genótipos de Capsicum annuum

\begin{tabular}{|c|c|c|c|c|}
\hline \multirow{4}{*}{$\begin{array}{l}\text { Severidade nas plântulas } \\
\text { (escala de notas) }\end{array}$} & \multicolumn{4}{|c|}{ Avaliações nos frutos } \\
\hline & \multicolumn{3}{|c|}{ Diâmetro de lesões (cm) } & \multirow{3}{*}{$\begin{array}{l}\text { Vel. Cresc. } \\
\text { (cm/dia) }^{1}\end{array}$} \\
\hline & 3 DAI & 7 DAI & 11 DAI & \\
\hline & \multicolumn{3}{|c|}{ Primeiro Experimento } & \\
\hline \multirow[t]{2}{*}{3 DAI } & $0,37^{2}$ & 0,31 & 0,26 & 0,18 \\
\hline & $0,0009 *$ & $0,005 *$ & $0,023 *$ & $0,12^{\mathrm{NS}}$ \\
\hline \multirow[t]{2}{*}{10 DAI } & 0,39 & 0,37 & 0,32 & 0,25 \\
\hline & $0,0005 *$ & $0,001 *$ & $0,004 *$ & $0,04 *$ \\
\hline \multirow[t]{2}{*}{19 DAI } & 0,41 & 0,37 & 0,32 & 0,24 \\
\hline & $0,0002 *$ & $0,0009 *$ & $0,005 *$ & $0,04 *$ \\
\hline \multicolumn{5}{|c|}{ Segundo Experimento } \\
\hline \multirow[t]{2}{*}{3 DAI } & 0,26 & 0,26 & 0,19 & 0,13 \\
\hline & $0,17^{\mathrm{NS}}$ & $0,17^{\mathrm{NS}}$ & $0,31^{\mathrm{NS}}$ & $0,49^{\mathrm{NS}}$ \\
\hline \multirow[t]{2}{*}{10 DAI } & 0,16 & 0,25 & 0,33 & 0,33 \\
\hline & $0,41^{\mathrm{NS}}$ & $0,17^{\mathrm{NS}}$ & $0,08^{\mathrm{NS}}$ & $0,08^{\mathrm{NS}}$ \\
\hline \multirow[t]{2}{*}{19 DAI } & 0,20 & 0,28 & 0,33 & 0,31 \\
\hline & $0,30^{\mathrm{NS}}$ & $0,14^{\mathrm{NS}}$ & $0,08^{\mathrm{NS}}$ & $0,09^{\mathrm{NS}}$ \\
\hline
\end{tabular}

Tabela 8 Análise de correlação entre o diâmetro de lesões aos 3, 7 e 11 dias após a inoculação e velocidade de crescimento de lesões nos frutos e a severidade nas plântulas aos 3, 10 e 19 DAI e teste F. Genótipos de Capsicum baccatum

\begin{tabular}{|c|c|c|c|c|}
\hline \multirow{4}{*}{$\begin{array}{l}\text { Severidade nas plântulas } \\
\text { (escala de notas) }\end{array}$} & \multicolumn{4}{|c|}{ Avaliações nos frutos } \\
\hline & \multicolumn{3}{|c|}{ Diâmetro de lesões (cm) } & \multirow{3}{*}{$\begin{array}{l}\text { Vel. Cresc. } \\
{\text { (cm/dia })^{1}}^{\text {(cm }}\end{array}$} \\
\hline & 3 DAI & 7 DAI & 11 DAI & \\
\hline & \multicolumn{3}{|c|}{ Primeiro Experimento } & \\
\hline \multirow[t]{2}{*}{3 DAI } & $0,02^{2}$ & $-0,05$ & $-0,03$ & $-0,06$ \\
\hline & $0,97^{\mathrm{NS}}$ & $0,83^{\mathrm{NS}}$ & $0,91^{\mathrm{NS}}$ & $0,80^{\mathrm{NS}}$ \\
\hline \multirow[t]{2}{*}{10 DAI } & 0,09 & 0,03 & 0,05 & 0,02 \\
\hline & $0,67^{\mathrm{NS}}$ & $0,88^{\mathrm{NS}}$ & $0,82^{\mathrm{NS}}$ & $0,94^{\mathrm{NS}}$ \\
\hline \multirow[t]{2}{*}{19 DAI } & 0,16 & 0,09 & 0,08 & 0,03 \\
\hline & $0,47^{\mathrm{NS}}$ & $0,69^{\mathrm{NS}}$ & $0,73^{\mathrm{NS}}$ & $0,89^{\mathrm{NS}}$ \\
\hline \multicolumn{5}{|c|}{ Segundo Experimento } \\
\hline \multirow[t]{2}{*}{3 DAI } & $-0,09$ & 0,33 & 0,35 & 0,43 \\
\hline & $0,78^{\mathrm{NS}}$ & $0,28^{\mathrm{NS}}$ & $0,27^{\mathrm{NS}}$ & $0,16^{\mathrm{NS}}$ \\
\hline \multirow[t]{2}{*}{10 DAI } & 0,17 & 0,18 & 0,32 & 0,35 \\
\hline & $0,59^{\mathrm{NS}}$ & $0,57^{\mathrm{NS}}$ & $0,32^{\mathrm{NS}}$ & $0,27^{\mathrm{NS}}$ \\
\hline \multirow[t]{2}{*}{19 DAI } & 0,36 & 0,21 & 0,16 & 0,16 \\
\hline & $0,25^{\mathrm{NS}}$ & $0,511^{\mathrm{NS}}$ & $0,63^{\mathrm{NS}}$ & $0,62^{\mathrm{NS}}$ \\
\hline
\end{tabular}


Tabela 9 Análise de correlação entre o diâmetro de lesões aos 3, 7 e 11 dias após a inoculação e velocidade de crescimento de lesões nos frutos e a severidade nas plântulas aos 3, 10 e 19 DAI e teste F. Genótipos de Capsicum chinense

\begin{tabular}{|c|c|c|c|c|}
\hline \multirow{3}{*}{$\begin{array}{l}\text { Severidade nas plântulas } \\
\text { (escala de notas) }\end{array}$} & \multicolumn{4}{|c|}{$\begin{array}{l}\text { Avaliações nos frutos } \\
\end{array}$} \\
\hline & \multicolumn{3}{|c|}{ Diâmetro de lesões (cm) } & \multirow{2}{*}{$\begin{array}{l}\text { Vel. Cresc. } \\
(\mathrm{cm} / \mathrm{dia})^{1}\end{array}$} \\
\hline & 3 DAI & 7 DAI & 11 DAI & \\
\hline \multirow[t]{2}{*}{3 DAI } & $-0,55^{2}$ & $-0,45$ & $-0,42$ & $-0,14$ \\
\hline & $0,15^{\mathrm{NS}}$ & $0,27^{\mathrm{NS}}$ & $0,30^{\mathrm{NS}}$ & $0,74^{\mathrm{NS}}$ \\
\hline \multirow[t]{2}{*}{10 DAI } & $-0,09$ & $-0,43$ & $-0,50$ & $-0,46$ \\
\hline & $0,82^{\mathrm{NS}}$ & $0,29^{\mathrm{NS}}$ & $0,21^{\mathrm{NS}}$ & $0,25^{\mathrm{NS}}$ \\
\hline \multirow[t]{2}{*}{19 DAI } & $-0,08$ & $-0,61$ & $-0,71$ & $-0,68$ \\
\hline & $0,85^{\mathrm{NS}}$ & $0,11^{\mathrm{NS}}$ & $0,05^{\mathrm{NS}}$ & $0,06^{\mathrm{NS}}$ \\
\hline
\end{tabular}

Tabela 10 Comparação entre diâmetro de lesões nos frutos aos 11 dias após a emergência e a severidade nas plântulas aos 19 dias após a emergência, para alguns acessos selecionados de $C$. annuum

\begin{tabular}{|c|c|c|c|c|c|c|c|}
\hline \multicolumn{4}{|c|}{ Severidades em plântulas acima de 2,0} & \multicolumn{4}{|c|}{ Severidade em plântulas abaixo de 1,20 } \\
\hline $\mathbf{N}^{\circ}$ & Acessos & $\begin{array}{c}\text { Severi- } \\
\text { dade }\end{array}$ & $\begin{array}{l}\text { Diâm. } \\
\text { lesão }\end{array}$ & $\mathbf{N}^{\circ}$ & Acessos & $\begin{array}{c}\text { Severi- } \\
\text { dade }\end{array}$ & $\begin{array}{l}\text { Diâm. } \\
\text { lesão }\end{array}$ \\
\hline 3 & \# 138 & 2,0 & 2,3 & 2 & \# 132 & 1,1 & 2,1 \\
\hline 5 & \# 5 & 3,1 & 1,9 & 8 & Ancho & 1,2 & 2,9 \\
\hline 6 & \# 125 & 2,3 & 2,5 & 9 & Ano todo & 1,1 & 2,0 \\
\hline 7 & Agronômico 10G & 3,8 & 2,4 & 14 & BGH 3058 & 1,0 & 2,9 \\
\hline 24 & BGH 3978 & 2,5 & 2,6 & 18 & BGH 3757 & 1,2 & 2,2 \\
\hline 25 & BGH 3464 & 2,1 & 3,2 & 26 & BGH 3714 & 1,1 & 2,1 \\
\hline 38 & Calahora & 3,8 & 3,4 & 31 & BGH 3881 & 1,1 & 2,4 \\
\hline 46 & CNPH 146 & 2,1 & 2,4 & 32 & BG 3883 & 1,2 & 2,1 \\
\hline 47 & CNPH 162 & 2,2 & 2,2 & 33 & BGH 3888 & 1,1 & 2,2 \\
\hline 54 & IAC 8 Mogi & 2,4 & 3,9 & 40 & Catarino Cascabel & 1,0 & 0,7 \\
\hline 55 & ICA \# 12 & 2,9 & 2,5 & 44 & CNPH 144 & 1,1 & 1,8 \\
\hline 57 & ICA \# 132 & 2,3 & 2,0 & 48 & CNPH 185 & 1,2 & 3,0 \\
\hline 60 & Jalapeno & 2,3 & 2,4 & 56 & ICA \# 131 & 1,0 & 1,0 \\
\hline 62 & Kan Cluster & 2,5 & 2,3 & 59 & Jalapeno & 1,2 & 2,1 \\
\hline 64 & Marconi & 2,2 & 3,7 & 61 & Jalapenho (Cica) n ${ }^{\circ}$ & 1,1 & 0,6 \\
\hline 68 & Mulato V-2 & 2,0 & 2,6 & 63 & Maalab & 1,2 & 2,4 \\
\hline 73 & PI 188476 & 2,3 & 1,2 & 67 & Mulato Dulce & 1,2 & 1,6 \\
\hline 75 & $\begin{array}{l}\text { Pimenta Ornament } \\
\text { Picante P } 01\end{array}$ & 2,4 & 2,4 & 113 & IAC \# 63 & 1,2 & 1,8 \\
\hline 77 & Pimenta Roque & 2,4 & 2,5 & 132 & Pimenta Doce IH 1744 & 1,1 & 1,9 \\
\hline 80 & $\mathrm{R}-17$ & 2,4 & 2,1 & 214 & Arivivi \# 261 & 1,0 & 0,6 \\
\hline 211 & Aji Rojo \# 258 & 2,8 & 2,1 & 231 & ICA \# 64 & 1,1 & 2,0 \\
\hline 227 & BGH 5122 & 4,3 & 2,8 & 233 & Jalapeno & 1,1 & 0,2 \\
\hline 303 & BGH 3759 & 2,1 & 2,0 & 300 & \# 17 & 1,2 & 2,3 \\
\hline 304 & BGH 3887 & 3,0 & 3,6 & & & & \\
\hline 305 & BG 3757 & 2,7 & 3,2 & & & & \\
\hline 341 & Arivivi \# 142 & 2,1 & 2,1 & & & & \\
\hline
\end{tabular}

